\title{
Changing religious structures and civil society in Latin America: The case of Nicaragua
}

\author{
John G. Poffenbarger \\ West Virginia University
}

Follow this and additional works at: https://researchrepository.wvu.edu/etd

\section{Recommended Citation}

Poffenbarger, John G., "Changing religious structures and civil society in Latin America: The case of Nicaragua" (2005). Graduate Theses, Dissertations, and Problem Reports. 2308.

https://researchrepository.wvu.edu/etd/2308

This Dissertation is protected by copyright and/or related rights. It has been brought to you by the The Research Repository @ WVU with permission from the rights-holder(s). You are free to use this Dissertation in any way that is permitted by the copyright and related rights legislation that applies to your use. For other uses you must obtain permission from the rights-holder(s) directly, unless additional rights are indicated by a Creative Commons license in the record and/ or on the work itself. This Dissertation has been accepted for inclusion in WVU Graduate Theses, Dissertations, and Problem Reports collection by an authorized administrator of The Research Repository @ WVU.

For more information, please contact researchrepository@mail.wvu.edu. 


\title{
CHANGING RELIGIOUS STRUCTURES AND CIVIL SOCIETY IN LATIN AMERICA: THE CASE OF NICARAGUA
}

\author{
by \\ John G. Poffenbarger \\ Dissertation submitted to the Eberly College of Arts and Sciences \\ at West Virginia University \\ in partial fulfillment of the requirements \\ for the degree \\ Doctor of Philosophy \\ in \\ Political Science
}

\author{
Approval by \\ Donley T. Studlar, Ph.D., Committee Chair Person \\ Richard Brisbin, Ph. D \\ Susan Hunter, Ph. D. \\ Jamie E. Jacobs, Ph.D. \\ John Super, Ph.D. (History) \\ Department of Political Science \\ Morgantown, West Virginia \\ 2005
}

Key Words: Nicaragua, Civil Society, Religion

Copyright: 2005 John G. Poffenbarger 


\title{
Abstract \\ CHANGING RELIGIOUS STRUCTURES AND CIVIL SOCIETY IN LATIN AMERICA: THE CASE OF NICARAGUA
}

\author{
by John G. Poffenbarger
}

Two phenomena have been ongoing in Central America over the past 30 years. The first has been a change in the dominant religious structures in the region with the growth of Evangelical Protestantism and Pentecostalism, as well as ongoing changes within the Roman Catholic Church, such as the rise and fall of Progressive Catholicism. The other major phenomenon has been the establishment of democratic regimes across the isthmus. Putnam, Inglehart, Almond \& Verba, among others, assert that for a democracy to flourish a vibrant civil society must be present. These scholars, along with Huntington, Weber, and Wald et al. believe that religious institutions are among the most efficient providers of civil society because of their size and type of associational activity. Furthermore, some religious institutions are more conducive to democracy than others.

This paper examines support for democracy to determine which religious institutions produce the strongest civil society. It also examines whether this religious trend supports or undermines democratization efforts. Using survey data collected in the spring and summer of 2003 in the Granada, Managua, Masaya, and Pueblos Blancos areas of Nicaragua, the paper tests the differences in the forms of civil society produced based on the associational activities undertaken by people from specific denominations. 


\section{ACKNOWLEDGEMENTS}

The author would like to thank the numerous individuals for their support throughout the painful days of graduate work. First, I would like to thank Senator John T. Poffenbarger and Charleston Artist Susan G. Poffenbarger for the unwavering support. I would like to thank my wife Molly Poffenbarger whose patience and support throughout the process have gone beyond the vows of marriage. To my sisters Helen Jordan and Kathryn Colver, and their families, whose acts of kindness and generosity made graduate school tolerable. Finally, to Cletus and Lupita, the best dogs two people can have.

The author would also like to thank numerous faculty and staff for their assistance throughout my graduate career. I would like to thank Dr. Donley T. Studlar whose mentorship was vital in completing my academic training. I would like to thank Dr. Jamie Jacobs for encouraging me to jump head first into the field work and patiently listening to my numerous, and often tedious, questions. I would like to thank Dr. Susan Hunter for taking a chance on a mediocre graduate student by providing me with my first graduate position. I would like to thank Dr. Richard Brisbin and Dr. John C. Super for their support and advice throughout the dissertation process. I would like to thank all of the professors in the WVU Department of Political Science who provided me with invaluable instruction: Dr. John C. Kilwein, Dr. Allan Hammock, Dr. Joe Hagan, Dr. Robert D. Duval, Dr. Kevin M. Leyden, and Dr. Jeffery S. Worsham. Finally, I would like to thank the staff in the WVU Department of Political Science: Ms. Lee Ann Greathouse, Ms. Donna MacIsaac, and Ms. Rebecca Digman. Finally, I would like to thank Dr. Jill Kriesky, for allowing me to work at the WVU Office of Service Learning as long as I needed to, and Dr. Timothy White, at Xavier University, for his continuous encouragement.

There are also a number of people in Nicaragua without whom the fieldwork for this dissertation could not have been completed: John Pignato, my Godfather who helped us get our feet wet; Donna Tabor, owner of Another Night in Paradise, who was patient with our stupid questions and allowed us to live there for four months; Sergio Daniel Canudas and Maria Auxiliadora Navarro, the staff at ANP; and Julio Morales, my research assistant.

All omissions and mistakes in this dissertation are mine alone. 


\section{$\underline{\text { Table of Contents }}$}

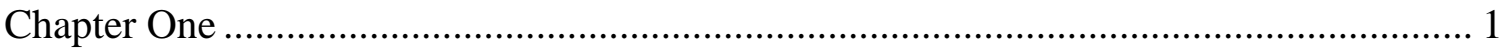

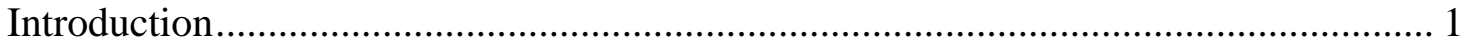

The Outline of this Dissertation................................................................................. 4

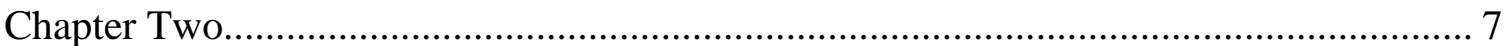

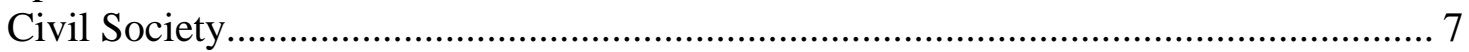

Religion, Civil Society, and Democracy.................................................................... 11

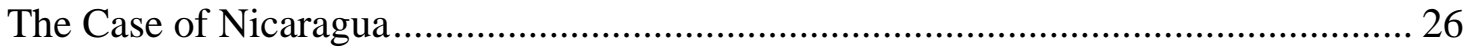

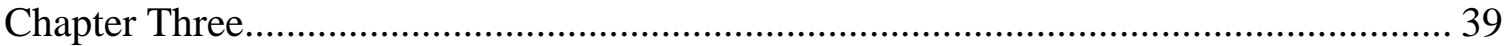

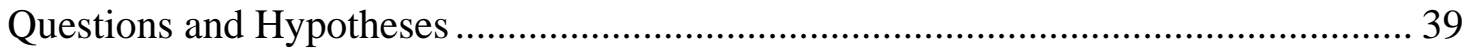

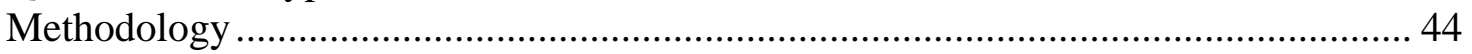

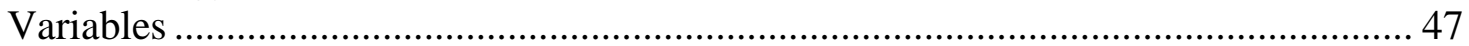

Civil Society Dependent Variables............................................................................. 49

Effects of Civil Society Dependent Variables ............................................................... 51

Religious Denomination Independent Variables ......................................................... 57

Religiosity Independent Variables.............................................................................. 59

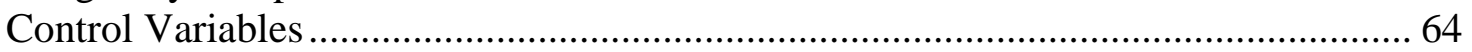

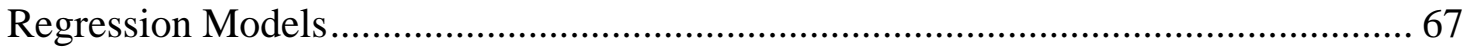

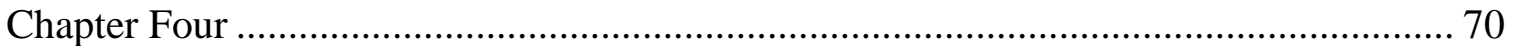

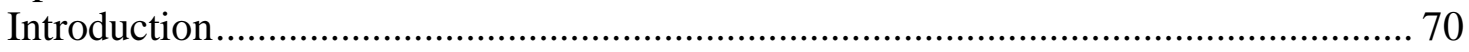

The State of Formal Civil Society in Nicaragua.......................................................... 70

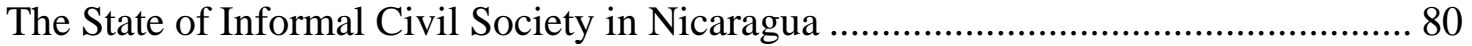

Effects of Civil Society Support and Participation ........................................................ 86

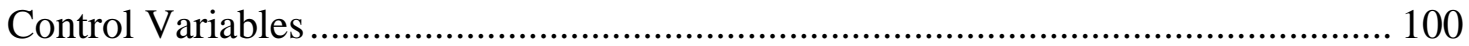

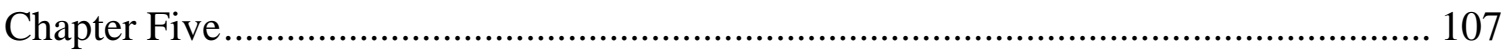

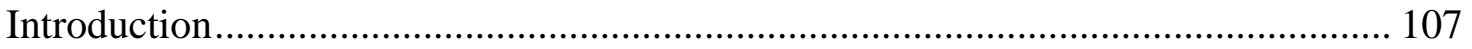

Religious Denomination in Nicaragua.................................................................. 107

Religious Denominations and Civil Society …………............................................. 122

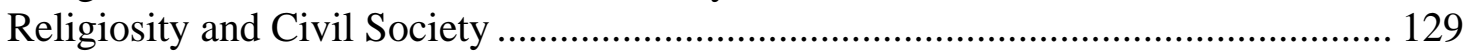

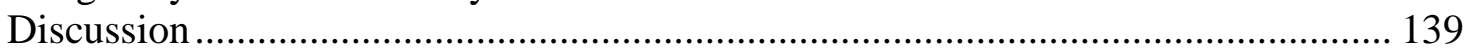

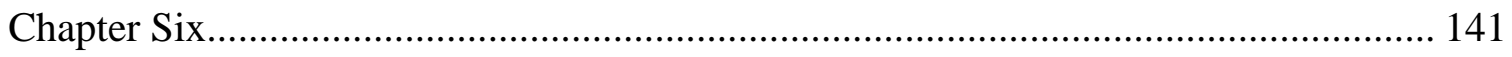

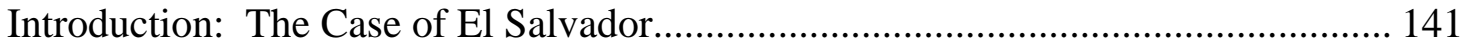

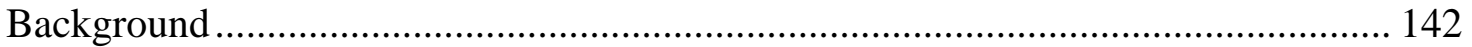

Religious Denomination in El Salvador (WVS: V179) ......................................... 144

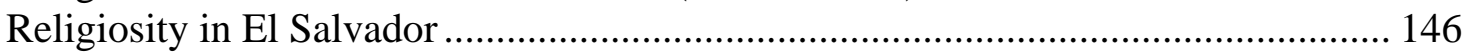

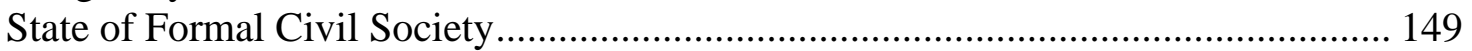

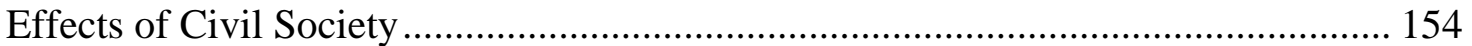

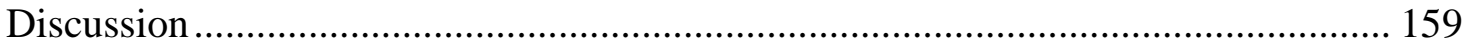

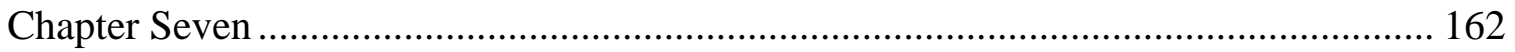

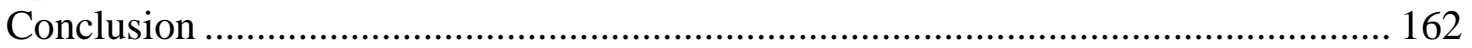

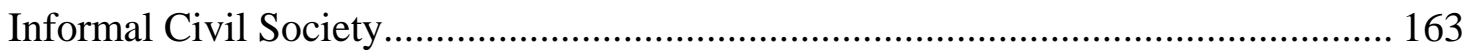

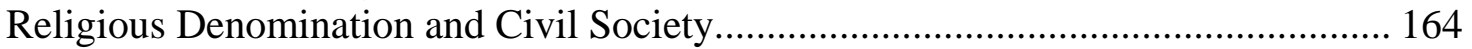

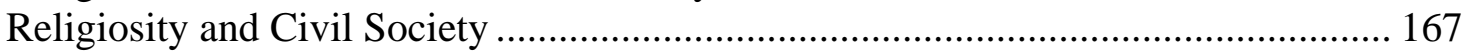




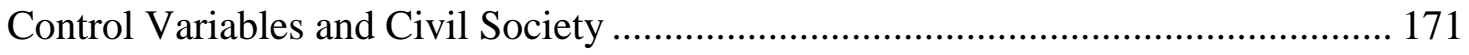

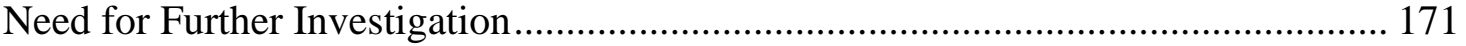

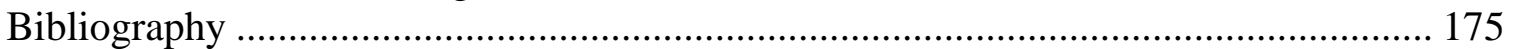

Appendix 1: Code Book for the 2003 Nicaraguan Survey Instrument......................... 183

Appendix 2: Index Variable Definitions................................................................ 205 


\section{$\underline{\text { List of Tables }}$}

Table 4-1: Summary Table For the Formal Civil Society Index (FOCIND2)................. 71

Table 4-2: Member of a Political Party (FOCPP)....................................................... 73

Table 4- 3: Left - Right Political Continuum (GCLRC) ….......................................... 74

Table 4-4: Summary Table for Informal Civil Society Participation Index (ICSPIN).... 82

Table 4-5: Summary Table for Informal Civil Society Support Index (ICSSIN)........... 84

Table 4-6: Summary Table for Informal Civil Society Participation and Support Index

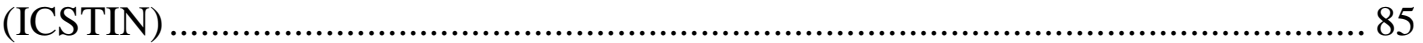

Table 4-7: Summary Table for Political Efficacy Index (POLEF)................................ 88

Table 4-8: Summary Table for Political Knowledge Index (PKIND) ............................. 89

Table 4-9: Summary Table for Interpersonal Trust Index (IPTRUST) .......................... 90

Table 4-10: Summary Table for Belief That Government Actions Are Correct Index

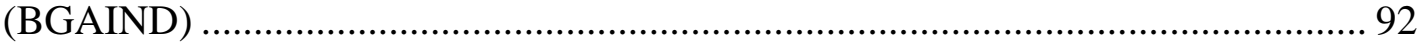

Table 4-11: Summary Table for Confidence in Governmental Institutions (CIGIND)... 94

Table 4-12: Summary Table for Tolerance of Alternative Political Expression Index

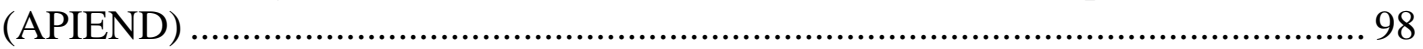

Table 4-13: Openness of Political Participation for Those Expressing Negative Views (OPINDX)

Table 4-14: Summary Table for Minimum Family Monthly Income (DIINF) ............. 101

Table 4-15: Summary Table for Age (DIAGE1) .................................................... 103

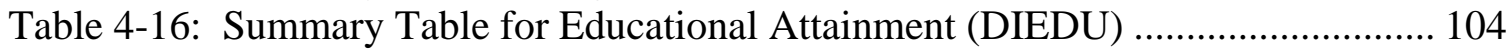

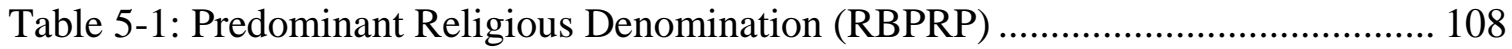

Table 5-2: Primary Religious Provider (RBPRP4) ................................................... 110

Table 5-3: Member of More Than One Denomination (RBMOD) .............................. 111

Table 5-4: Reason For Conversion (RBRFC)........................................................... 112

Table 5-5: "Please indicate whether you believe in any of the following (RBWTB1-9) 117

Table 5-6: "Should the Church speak out on these issues...(RBCRS)?” ..................... 120

Table 5-7: "Is the Church providing adequate answers to ...(RBCPA)?”...................... 121

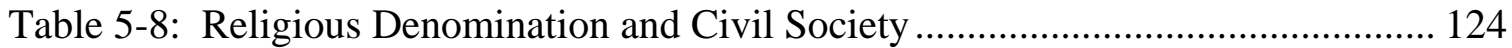

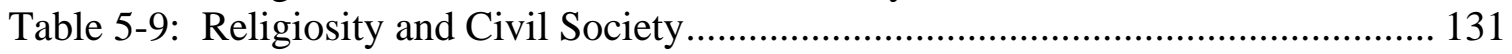

Table 5-10: Individual Religiosity Variables and Civil Society .................................. 132

Table 5-11: Role of Religious Institutions in Society (TOTAL) and Civil Society ...... 136

Table 5-12: View of Religious Success (RBCPAI) and Civil Society ........................ 138

Table 6-1: Religious Denominations in El Salvador ................................................. 144

Table 6-2: “How often do you attend religious services ?”-- El Salvador..................... 146

Table 6-3: "Do you find strength and comfort from religion ?”.................................. 147

Table 6-4: Please indicate whether you believe in any of the following .................... 148

Table 6-5: Membership in Formal Civil Society Organizations - El Salvador ............. 150

Table 6-6: Political Self-placement on the Left-Right Continuum in El Salvador and

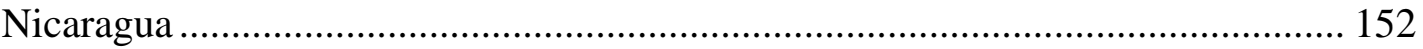

Table 6-7: How much confidence do you have in the following institutions? ............... 155

Table 6-8: Have you ever participated in the following form of political expression?

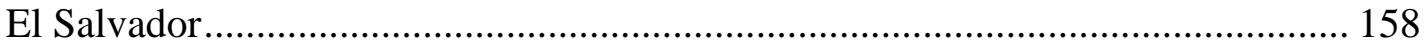




\section{$\underline{\text { List of Figures }}$}

Figure 2-1: Historical Timeline of Nicaragua........................................................ 27

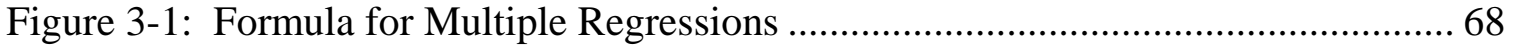




\section{List of Acronyms}

ANDEN

ATC

CAUS

CEB

CELAM

CGTR-I

CONAPRO

COSEP

CPT

CST

CTN-A

CTN

CUS

FETASALUD

FNT

FSLN

MRS

PALI

PCCN

PCN

PLC

PLI

PLIUN

PRN

PUCA

MARENA

MAGFOR

Vatican II

UNAG

UNE

UNO
National Association of Educators in Nicaragua

Farm Workers Association

Labor Action and Unity Central

Christian Base Communities

Latin America Bishops Conference in Medillin, Columbia

Independent General Confederation of Labor

Heroes and Martyrs Confederation of Professional Associations

Superior Council of Private Enterprise

Permanent Congress of Workers

Sandinista Workers Central

Autonomous Nicaraguan Workers Central

Nicaraguan Workers Central

Confederation of Labor Unification

Health Workers Federation

National Workers Front

Sandinista National Liberation Front

Sandinista Revolution Movement

Nicaraguan Party of the Christian Path

National Party for the Christian Road

Conservative Party of Nicaragua

Liberal Constitution Party

Independent Liberal Party

Independent Liberal Party for National Unity

Nicaraguan Resistance Party

Central American Unionist Party

Ministry of Environment and Natural Resources

Ministry of Agriculture and Forestry

Second Vatican Council

National Union of Farmers and Ranchers

National Union of Employees

National Opposition Union 


\section{Chapter One}

\section{Introduction}

The past thirty years have provided Central America with major shifts in its dominant political and social institutions. A once dominant Roman Catholic region has experienced fragmentation in the Roman Catholic Church, as well as an opening for other religious actors. These fragmentations and openings have lead to a sharp rise in alternative forms of religious practice, especially Evangelical Protestantism and Pentecostalism. Coinciding with religious changes has been a wave of democratization taking hold with a level of stability unprecedented in the region. Religion and politics tend to interact most frequently in the realm of civil society, which is commonly defined as the area outside the state where autonomous societal groups articulate and advance their interests or the general politicization and popular activation of societal groups (Linz and Stepan 1996, p. 16; Fukyama 1995, p. 7; Gellner 1994, p. 5; O’Donnell 1986, p. 26).

The coincidence of these movements leads to questions of whether they are related in some way. Furthermore, if a relationship does exist, which of these phenomena is the driving force? Finally, are these new democratic and religious phenomena simply trends that will eventually wane or are they becoming a long-term part of the sociopolitical reality in Central America?

To gain a thorough understanding of these phenomena this dissertation will utilize concepts found in the civil society literature to explore the relationship between religious institutions and their contribution to creating a civil society capable of sustaining democratic political institutions in Nicaragua. Using data collected in the spring and 
summer of 2003 from the Granada, Managua, Masaya, and Pueblos Blancos areas of Nicaragua , this research examines the growing Evangelical Protestant and Pentecostal movements in Nicaragua to determine whether they are contributing to civil society in ways that aid democratization efforts in the politically tumultuous region.

Despite assertions that these particular religious movements may not contribute to civil society because of their inward focus, this research will argue that religion is essentially a product of the culture in which it is practiced. In Nicaragua Fundamental Protestantism and Pentecostalism may be one of the most prominent pro democratic forces to emerge in civil society.

Rather than examining civil society as a whole, as has been the tradition in recent research (Brysk 2000; Galston 2000; Booth and Richard 1998; Fukuyama 1995; Gellner 1994; Seligman 1992), the concepts of civil society will be broken down to specific effects and activities to determine how particular actors within civil society affect the overall form. As many studies have noted, different forms of civil society produce different outcomes in the political arena. Some forms of civil society may promote democratic institutions; others may produce anti-regime attitudes, while still others may produce violent and confrontational attitudes independent of government structures (Booth and Richard 1998; Foley and Edwards 1996).

The research explores both the differences between religious structures in producing pro-democratic attitudes through their associational activities, as well as their role enriching civil society as a whole through encouraging activation of other actors. There is no attempt to establish a direct causal correlation between religion and democracy. This research is simply suggesting that religious institutions are important 
actors within civil society and that the composition of civil society is an important variable in the establishment and maintenance of democratic institutions. Therefore, the intent of this research is to investigate the different religious forms that contribute to civil society, and their role in producing attitudes and beliefs capable of maintaining democratic institutions. The current Nicaraguan religious forms of Evangelical Protestantism and Pentecostalism are not generalizable across all cases; after all, religion is a cultural phenomenon. Inglehart (1988) claims that societies are characterized by their political culture attitudes and these attitudes are enduring, but not immutable. Thus, as these inputs change from Traditional Catholicism to Evangelical Protestantism and Pentecostalism, so too will civil society. As these forms of civil society become an integral part of society, the political culture will also change.

The central question of this research is to what extent do different religious structures, practices, and orientations produce different forms of civil society? Are some religious orientations, and the specific form of associational activities encompassed within them, more likely to produce a civil society capable of establishing and maintaining democratic institutions than other religious forms? More specifically, does Pentecostalism, because of its role in redefining community and creating a safe haven from the hardships of every day life, produce a civil society better able at maintaining democratic institutions than either Traditional Catholicism or Progressive Catholicism? Does Traditional Catholicism, because of its hierarchical structure and mediated relationship with God, create a civil society conducive to authoritarian forms of government? Does Progressive Catholicism, as born out of liberation theology and 
structured in CEBs, create an anti-regime civil society? Does Evangelical Protestantism produce a civil society capable of establishing and maintaining democratic institutions?

To help answer these complex but important questions a number of hypotheses have been generated.

H1. Pentecostalism will have a positive significant relationship with a civil society capable of establishing and maintaining democratic institutions.

H2. Evangelical Protestantism will have a positive significant relationship with a civil society capable of establishing and maintaining democratic institutions.

H3. Traditional Catholicism will have a negative significant relationship with a civil society a capable of establishing and maintaining democratic institutions.

H4. Progressive Catholicism, as espoused by Liberation Theology, will have a negative significant relationship with a civil society capable of establishing and maintaining democratic institutions.

H5. Charismatic Catholicism will have a positive significant relationship with a civil society capable of establishing and maintaining democratic institutions

\section{The Outline of this Dissertation}

Chapter Two reviews the literature on the effects of the different religious structures and how they affect civil society and thus democracy. It begins with an exploration and definition of civil society and who the actors are and continues with an analysis of different views regarding the importance of religious actors in civil society. The chapter further delineates the differences and similarities between Traditional Roman Catholicism, Progressive Catholicism, and Charismatic Catholicism, as well as Evangelical Protestantism and Pentecostalism. Finally, Chapter Two provides an investigation of Nicaragua's political and religious history to provide context for the research. 
Chapter Three establishes the conceptualization of civil society into measurable variables. The chapter further explains the construction of index variables produced to offer an accurate measure of all the concepts encompassed within civil society. It addresses the survey methodology used to specifically measure civil society structure and effects. Finally, the chapter provides an explanation of the statistical analysis implemented to explain the role of religion in civil society.

Chapter Four provides a descriptive analysis and discussion of the current state of civil society in Nicaragua. It begins with an exploration of the state of formal civil society actors and the level of participation in officially established organizations. The second section of the chapter examines participation in informal civil society through participating and donating money or material to informal organizations at the neighborhood or barrio level. The chapter then examines the effects of civil society participation such as political efficacy, interpersonal trust, institutionalization of democratic principles, and attitudes towards governmental institutions. Finally, this chapter supplies an analysis of other possible explanatory variables such as gender, educational attainment, income, and age.

Chapter Five begins with a discussion of the state of religion in Nicaragua. First is an exploration of the adherence to various religious denominations and forms under investigation. The chapter also explores the levels of religiosity through index variables examining the level of religious belief, value, and participation. This chapter also provides the results for the multiple regression analysis used to determine the relationships between religious denomination, religiosity, and the state of civil society in Nicaragua. 
Chapter Six presents analysis in a comparative perspective with El Salvador, using data provided by World Values Survey. World Values Survey data comes from the 1995-1996 third wave of the survey. Incomplete as the data on El Salvador may be, it does provide similar data to that collected for Nicaragua to provide a comprehensive comparison of religious denomination, religiosity, rates of participation, and effects of civil society. Finally, Chapter Seven provides the conclusions to this research which essentially find that adherence to specific religious denomination is fluctuating and association with denomination only has a minor effect on civil society. However, the level of religiosity does have an effect on civil society participation and the production of attitudes capable of establishing and maintaining democratic institutions in both Nicaragua and El Salvador. 


\section{Chapter Two}

\section{Civil Society}

What is civil society? According to the United Nations Development Program civil society:

“...Embraces an immense range of human activity outside both the market and the state, but linked with constant interaction and mutual influence with both. It is often described as the space between the citizen and the state where the will of the citizen is manifested and mobilized outside official auspices”

(http://www.undp.org/csopp/CSO/NewFiles/faqs.htm)

While this definition provides a concise view of civil society, the rich literature surrounding the concept has its roots in the French, German, and Scottish Enlightenments (Seligman 1992, p. 5). For Seligman (1992, p. 5), civil society, in its purist sense, is that arena where the private individual seeks his or her own self-interest. Thus, civil society is essentially an arena for the aggregation of personal interests. However, what interests Seligman is the idea found in Western thought that the individuals encompass some metaphysical or moral values in these pursuits. He credits Weber for tracing it back to the "Reformation Religions” (Seligman 1992, pp. 5-6). It appears that mores and values founded in religious and other beliefs about working for the pursuit of interests in the aggregate is what makes society “civil” or provides the norms for peaceful interaction among individuals in a society. It is the idea that civil society can be traced back to religious mores and values that make exploring its effect on contemporary democratization in Latin America a worthwhile endeavor.

Linz and Stepan (1996, p. 17) define civil society as an arena for "selforganization” where relatively autonomous groups articulate interests, create associations, and advance their interests. Fukuyama (1995, p. 7) claims it is the realm of 
spontaneously created social structures, separate from the state and underlying democratic political institutions. For Gellner (1994, p. 5) civil society is a set of diverse non-governmental institutions that counterbalance the state, but does not stop it from fulfilling its role as peacekeeper and arbitrator of interests. In the context of Latin America and the “decompression” of authoritarian rule, O’Donnell (1986, p. 26) describes the "resurrection of civil society" as a sharp increase in general politicization and popular activation.

A number of scholars, inspired by de Tocqueville (1835), have put forth the idea that civil society is essentially associational life, as well as patterns of association that foster habits of civility and organization in the actions of citizens in a democratic polity (Brysk 2001; Putnam 2000; 1995; 1993; Galston 2000; Ireland 1999; Booth \& Richard 1998; Foley \& Edwards 1996; de Tocqueville 1984, 1835). This form of civil society is known as civil society I. Foley and Edwards (1996, pp.38-41) extend their definition of civil society beyond the "Tocquevillian”, or civil society I, to include different forms of civil society. Civil society II is constituted of those forms of associational activity, in societies characterized by repression, such as in Central America that tend to be conflictual and anti-tyrannical. Group actions are capable of energizing resistance to a tyrannical regime. Booth and Richard (1998, pp. 781-782) extend the debate to include civil society III or groups that produce an uncivil society by generating violent and confrontation forms of associational activity. Groups of this type include the Klu Klux Klan, Neo-Nazis, skinheads, paramilitary groups, or death squads. These definitions are created to test the direction of Putnam's (1995, pp. 65-66) causal claim that the quality of 
public life and performance of social and political institutions are influenced norms and networks of civic engagement (Booth and Richard 1998, pp. 781-783).

The differences between civil societies I, II, and III are intriguing because they demonstrate that diverse forms of associational activity may produce disparate forms of civil society. Therefore, one can conceive that certain civil society actors may be efficient producers of democratic ideals or patterns of civility while others generate an anti-regime civil society depending upon the forms of associational activities within civil society. In essence, diverse civil society actors may produce assorted outcomes in terms of civil society output.

Who or what are civil society actors? Civil society actors come from all sectors of society. They may be born out of social movements such as women's groups, neighborhood associations, religious groups, academic or grass roots organizations, as well from all levels of socioeconomic status such as trade unions, entrepreneurial groups, and professional groups (Linz and Stepan 1996, p. 7; Brysk 2000, pp. 152-153). For Brysk (2000, pp. 152-153) civil society is more than just a list of actors, but includes all non-profit and non-governmental actors that provide associational life and produce social capital. Civil society actors serve as intermediaries between the government and the citizen, which may sometimes delegate authority on specific issues.

If civil society is associational activity outside of government fostering patterns of civility and producing trustworthiness in democratic institutions, then a look at these connections is necessary. Putnam (2000, pp. 19-22; 1995, pp. 65-67) claims that associational activity creates interpersonal trust through reciprocity, which in turn creates social capital that lubricates social life and creates trust in governmental institutions. 
Putnam (2000 pp. 17-23) defines social capital as the level of trustworthiness accumulated by individuals through social networks and positive reciprocal interactions with others. Putnam associates social capital with civil virtue that is created through participation in civil society.

Verba, Nye and Kim (1963) argue that participation in civil society organizations creates stimuli expanding people's worldview, thus encouraging individuals to participate in politics. Pateman (1970) claims participation teaches people the social skills and attitudes necessary for democracy to take root. Brysk (2000, p. 152) asserts that political functions of civil society in democratization include developing citizens, shaping the public agenda, and changing institutions through collective actions. Inglehart (1988, p. 1205) states the "viability" of democratic institutions is affected powerfully by attitudes about political efficacy, positive feelings about political institutions, and the belief that other citizens are trustworthy.

These effects of civil society are crucial because they shape attitudes about politics, but more importantly they shape attitudes about the legitimacy of political institutions. This is the essential basis of a state's political culture. Almond and Verba (1989, p. 13) define political culture as “...attitudes toward the political system and its various parts, and attitudes toward the role of the self in the system...It is a set of orientations toward a special set of social objects and processes.” Almond and Verba (1989, p. 14) further assert at the individual level political culture is defined by one's cognitive orientation or their knowledge and beliefs about the political system; affective orientation or feelings about the political system; and evaluation orientation judgments and opinions about political objects. Therefore, it appears that political culture is partly 
born out of civil society. This being the case, then one can assume the role of civil society in a democratic setting is directly to shape these orientations. As different forms of civil society or associational life produce different outcomes, they may also produce different political cultures.

The research here essentially draws on Brysk (2000), Booth and Richard (1998), Foley and Edwards (1996) and Inglehart (1988) to define civil society as associational activity outside the state that produces beliefs and attitudes conducive to the viability of democratic institutions. Moreover, diverse societal actors produce a variety of associational activities, which create a range of civil society forms and thus differing attitudes and beliefs towards democratic institutions. The concept of civil society is dissected to investigate which institutions produce attitudes and beliefs towards the maintenance and viability of democratic institutions. The research focuses on religious institutions because they are among the largest associations and organizations forming civic skills, civic norms, civic recruitment and community interest, as well as encompassing direct influence on culturally accepted beliefs and behaviors (Putnam 2000, pp. 66-67; Ireland 1999, p. 126; Castles 1998, p. 58; Wald, Owen, Hill 1990, pp. 197-198; Griffith, Plamentz and Pennock 1956, pp. 102-104, 113).

\section{Religion, Civil Society, and Democracy}

Religion has universally been acknowledged as an important variable in determining whether a state will turn towards democracy as a form of government (see Huntington 1991, pp.71-85; Lipset 1994, p. 5; Barro 1999, pp. 175-177). Some religious forms or denominations, due to their structure and specific characteristics, are conducive to democratic institutions while others are not. Religious practices and associational 
activities of the same denomination may differ depending on the culture where they are being practiced as time and societal changes force them to deal with new and more complex issues. For example, religious institutions are the most important societal institutions in countries with low human development since they perform the functions that educational and scientific institutions, the mass media, arts, museums, and philanthropic foundations, also fill in industrial societies (Inglehart and Norris 2004, Chapter 1; Inglehart 1988, p. 1221). Inglehart (1988, p. 1204) states that religion is a better predictor of electoral behavior than social class. To get a clearer understanding of these relationships, a survey of claims about the relationship between religion, democracy, and civil society must be conducted.

Weber (1934) explored the possible correlation and causal influences between Protestantism, the spirit of capitalism, and democracy. He found that religious ideals were important in terms of their relevance for collective action, whereby the convictions of a few become the convictions of many. Religion serves to maintain the reality of everyday life because religion engenders a legitimizing power that provides a comprehensive set of norms to aid the individual in marginal situations. Prior to Vatican II, Catholicism's contribution to defining culture was obedience to authority, collectivist values, and fatalism (Patterson 2004, pp. 345-347). Conversely, Weber found that Protestantism, due its religious focus on individual faith, priesthood of individuals, emphasis on elections, and approval of materialism “...created cultures of individuality, frugality, competition, and equality - the foundation of capitalist democracy” (Patterson 2004, p. 345). This relationship explained why in German business institutions Protestants held the majority of executive positions over the Catholic population. This 
thesis has allowed many scholars to put forth that Protestantism has been more likely to give rise to democratic regimes than Catholic ones (Lipset 1994, p. 5; Huntington 1991, pp. 72-78; Torres 1992; Weber 1934). Weber's thesis is significant because of the assertion that different religious orientations produced different outcomes in society as a result of different associational activities and practices encompassed in the different religions.

Huntington (1991) derives similar findings in his book about waves of democratization. He found that the first democratic wave occurred in Protestant countries. He attributed the first wave to the more democratic organization of Protestant churches, the stress on individual consciousness, and the individual relationship with God. The first wave of democratization lasted from 1826 until 1928 and consisted of Switzerland, the English “overseas dominions” and smaller European nations, England, France, Ireland, and Iceland. Argentina, Spain, and Italy were also among the 130 states establishing at least minimal democratic regimes before a reverse wave from 1922 through 1942 (Huntington 1991, pp. 16-19).

Starting during World War II first wave states assisted second wave states, like West Germany, Italy, Austria, Japan, and Korea in democratization through aid recovering from the devastation of war and de-colonization. Finally, third wave states democratizing in the 1970s, 1980s and 1990s, has been the result of loss of legitimacy of authoritarian states, changes in the Roman Catholic Church, global economic growth, a democratically conducive international environment, and a "snow-balling effect" or democratic diffusion. Overall thirty states in Europe, Latin America, and Asia replaced 
authoritarian regimes with democratic ones during the third wave (Huntington 1991, pp. 36-46).

Catholicism's previous failures at democratization had been attributed to its mediated relationship with God and its hierarchical or authoritarian structure as well as to poor economic development in Catholic countries. For Huntington (1991), increased democratic activity among third wave Catholic states was linked to doctrinal changes within the Roman Catholic Church. The Church became “... a powerful social institution in opposition to repressive regimes” rather than maintaining its traditional role as a source of legitimacy for the oligarchy and wealthy classes (Huntington 1991, pp. 77-85; Casanova 2001, p. 1043). This explanation implies that as the focus of the religious institution changed, so too did the associational activity within it, thus a change to a more democratic civil society. Huntington also states that economic growth during the third wave may have also been central to democratic growth.

Wald, Owen, and Hill (1990) show that churches can serve as effective transmitters of political information. They state that theological conservatism is a powerful predictor of moral conservatism and ideological self-identification on the part of the congregation. The connection between faith and politics extends well beyond voter choice to encompass partisan self-identification, political ideology, preferences for candidates, issue outlooks, and views toward a wide range of political objects. They find that churches function as political communities by promoting attitudinal consensus (Wald, Owen, and Hill 1990, pp. 197-198; 209-213). The influence of religion on civil society and politics is derived from highly salient or visible religious organizations providing much of the content of symbolic political attitudes. Griffith, Plamentz and 
Pennock (1956, pp. 102-104, 113) assert that religious institutions and practices shape the “mores" or "norms" of society.

For many citizens, group related attitudes provide the cognitive structures through which the political world can be simplified and understood. Religious group identifications have been shown to be important predictors of political attitudes among religious adherents and political elites (for a summary of the literature see Jelen 1992 pp. 692-696; Wald, Owen, and Hill 1990, p. 197). Ireland (1999, p. 111) argues that the popular religions growing in Latin America are building the necessary infrastructure to the maintenance of democracy parallel to the vital role religion played in the United States as shown by Alexis de Tocquiville.

This brief look at the effects of religious institutions on the viability of democratic institutions demonstrates an important relationship between religion and democracy. Religion is a provider of associational activities affecting the beliefs and attitudes of the individual adherent toward politics and the state structures. This relationship also reveals how different religious orientations influence the establishment of different political institutions. Protestantism is strongly correlated to democracy or capitalism and Catholicism traditionally less so, but has been gaining ground over the last quarter of the century. These religious shifts are of great consequence in Latin America as Evangelical Protestantism and Pentecostalism are challenging this once Catholic-dominated area of the world. To understand the effects of this movement, it is imperative to explore, not only the growth of Evangelical Protestantism and Pentecostalism, but also changes in the Traditional and Progressive Catholic Church and how these new and evolving institutions are affecting democratization efforts in the region and civil society. 


\section{Changes in Catholicism: Its Effect on Civil Society}

Traditional Roman Catholicism has engendered a negative relationship with democracy and the establishment of democratic institutions (Huntington 1991, p. 72; Lipset 1994, p. 5; Casanova 2001, p. 1043). Three causes have been cited for this relationship. Economically, Catholic countries have tended to be poorer. Economic development leads to democracy, which until recently many Catholic dominant states have been unable to achieve. Catholicism’s mediated relationship with God and authoritarian religious system structured within rigid ranks of priests, cardinals, and bishops has meant an authoritarian structure in the spiritual world may have developed similarly in the secular. Finally, traditional Roman Catholicism has habitually been a source for the legitimization of the military, dictatorial states, and upper classes (Casanova 2001, pp. 1042-1043; Bastian and Cunnen 1998, pp. 330-338; Sawchuk 1997, p. 39; Reuschmeyer ed. 1998; Lipset 1994, p. 5; Huntington 1991, pp. 72-76). As Sabia (1997, p. 12) states, “In Latin America, the establishment and rise to power of the Roman Catholic Church has been characterized by a close, often turbulent, relationship with wealthy elites and traditional authoritarian regimes.” As a result, Traditional Roman Catholicism has been associated with conservative views across most issues (Reichley, 1986; Castles 1998, p. 54). Thus, Traditional Catholicism has been a religion of conservatism, both spiritually and politically.

In Nicaragua the Traditional Church has always had close ties with the government and the elite classes. As Mulligan (1991, p. 65) points out, President Emiliano Chamorro gave the land for Managua's first Cathedral as a gift to the Church. In more recent times, upon the installment of Archbishop Obando y Bravo, the Somozas' 
provided him with a Mercedes that he used, but eventually gave away after much criticism (Sawchuk 1997, p. 42). Even the Catholic schools in Nicaragua were traditionally supported and attended by the small upper class, unconsciously operated to preserve the social structure (Mulligan 1991, pp. 70-72). Mulligan (1991, pp. 72-75) also notes that the Nicaraguan Catholic Church was not necessarily working directly in concert with elites, but was fulfilling a world wide Church doctrine in opposition to Communism.

"Progressive” or "Popular" Catholicism may run contrary to the conservatism of Traditional Catholicism (Williams 1992, Ch. 7). Progressive Catholicism was born out of Liberation Theology and the Church's preferential option for the poor. Established through the Second Vatican Council (Vatican II) and the Latin American Bishops Conference (CELAM), the Roman Catholic Church updated its social doctrine with a new stress on Catholicism's commitment to justice, extension of social outreach, and increased role of the laity (Vasquez 1999, pp. 1-2; Sabia 1997, pp. 12-28; Williams 1992 Ch.7). These innovations were structured as grassroots movements in Christian Base Communities (CEB's), which created new forms of associational activities through Bible reflection and social action projects.

CEBs began springing up in Latin America in the 1960s and were composed of small groups, usually ten to 25 people, meeting on a regular basis. Adherents, mostly from the poor and lower economic classes, use Bible reading and discussion to address common needs, resulting in some sort of cooperative action (Levine 1990, pp. 721-722). Levine (1990, p. 722) credits their organizational form as responses to various perceived 
social, political, and economic threats by working with and reinforcing existing friendships and community ties, thus putting religion into familiar and accessible content.

These associational activities have been hailed for helping the poor develop a critical understanding of national and local politics, acquire confidence and leadership skills, and establish social networks and alliances (Sabia 1997, pp. 33-47; Williams and Peterson 1996, pp. 873-897). Progressive Catholicism created an ethic of public engagement because doctrinally God is served through other humans. This public engagement is enhanced through the Progressive Church’s mission to serve the underprivileged and the belief that a just and peaceful world can be achieved through the cooperative interaction of humans (Ireland 1999, Levine 1992 , Drogus 1992). Studies of CEBs have shown how adherents have engaged in collective struggles for land, services, and rights and liberties (for a review see Ireland 1999). Stein (1998, pp. 13) states in El Salvador community organizing of religious actors prior to 1992 “...had a significant impact on public discourse about democratic values and the nation's political culture."

Unfortunately, Liberation Theology and the Progressive Church as CEB, appears to fall short in the long run (Deonandan 2001; Gill 1999; Ireland 1999; Lynch 1998; Daudelin and Hewitt 1995). Ireland (1999, p. 111) states:

“...the base communities [CEBS], which were to be at the same time both a 'new way of being church' and a source of new citizens, new civic communities, and a new civic culture - the very infrastructure for sustaining and deepening democracy -appear, against those high expectations, to have failed.”

Lynch (1998, pp. 269-270) and Stoll (1990, pp. 140-141) attributes the failure of Liberation Theology and Progressive Church to the focus of liberation priests, nuns, and laity on the concepts of Marxism to provide social analysis, combined with religious 
teachings. The problem is that these teachings do not empower the poor exclusively. The poor are treated with special care in the eyes of God because they are poor. Lynch (1998, pp. 269-270) also states that the Marxist principles’ encompassed within Liberation Theology rejects capitalism and democracy as they do not empower the poor. These religious assertions also create a "psychological blunder" by focusing on the pains and struggles of everyday life as a central tenet to Biblical teaching when people attend religious ceremonies to escape these hardships. The failure may also be a special case in Nicaragua because after Progressive Catholicism's success in influencing the revolution, it had achieved its main mission and lost its focus as a religious movement as hope under a new political system turned to reality.

The failure of the Progressive Church is one reason for the rise of Charismatic Catholicism in recent years. Built out of the middle classes' distrust of both the Traditional Roman Catholic Church and the Marxist ideals of Progressive Church, Charismatic Catholicism is able to provide an escape from the struggles of life. Looking similar to Evangelical Protestants and Pentecostals in Latin America, but modeled after Charismatic Catholics of North America, this movement is more interested in pastoral care than social movements. It focuses on devotion to the Bible, personal relationship with God, and the priority of Evangelism (Stoll 1990, pp. 27-30). Stoll (1990, p. 30) claims this is the least political of the three forms of Catholicism, but may have surpassed the Progressive Church in its influence at the local level. Charismatic Catholicism is of interest to this study because of its similarities to the Evangelical Protestantism and Pentecostalism sweeping the region; therefore it may have implications for the creation of civil society. 
Analysis of variations within Catholicism demonstrates the various forms of associational activity occurring within these institutions. Traditional Catholicism produces a civil society built around acceptance of authoritarian structures and conservative issues. On the other hand, Progressive Catholicism structured through CEBs produces associational activity reminiscent of civil society II, as it was at its strongest when it was the sole opposition voice to many Latin American dictatorships (Gill 1994, p. 403). Progressive Catholicism appeared to be a new form of civil society conducive to the establishment of democracy, but Lynch (1998) reminds us that its reliance on Marxist principles may have been its downfall in terms of adding to the viability of democratic institutions. Finally, Charismatic Catholicism may be producing democratic forms of civil society similar to those of Evangelical Protestantism and Pentecostalism.

The Growth of Evangelical Protestantism and Pentecostalism: Its Effect on Civil Society

The question now turns toward the effect of these new religious movements sweeping Latin America. The democratic transition in recent years has also brought about pluralism and fragmentation in the religious arena. Pluralism and fragmentation has opened up room for dialogue and practices challenging traditional actors, including the Roman Catholic Church (Vasquez 1991, p. 2). Gill (1999, p. 292) states that the proliferation of religious actors, such as Evangelical Protestantism, coincides with major social dislocations in the second half of the twentieth century. Noting that destitution was nothing new to the area, he states that aggravated levels of impoverishment, violence, and rural-urban migration have crushed traditional views of society (Gill 1999, pp. 292-293). According to Stoll (1990, pp. 8-10), ten percent of Latin Americans 
consider themselves evangelico, with higher percentages in Central America, Brazil, and Chile. Though the majority of Latin Americans still consider themselves Catholic, relatively few of these actually participate.

One explanation for the growth in Evangelical Protestantism and Pentecostalism may be the entrepreneurial roles of evangelical ministers, who both recruit members and secure financial resources (Daudelin and Hewitt 1995. pp. 221-237). These efforts have been aided by an influx of missionaries from abroad, with more than 54,000 from North America alone contributing to the growth of Evangelical Protestantism and Pentecostalism from 25 to 50 million people in a five-year period (1990-1995) (Daudelin and Hewitt 1995, pp. 221-237). This assistance has led most mission histories to assume that many of the structural and pastoral decisions of Evangelical Protestant and Pentecostal churches have been made from abroad (Cleary 1997, p. 8). This is not the case. These churches have been conceived and structured by "survival strategies" of Latin Americans rather than from their sister denominations of Europe and North America (Cleary 1997, p. 8; Mariz and Campos Machado in Cleary 1997, pp. 41-42). Evangelical and Pentecostal churches are essentially responsible for their own survival and have to adapt their teachings to the reality of their members to ensure the maintenance of the church. The independent structure of these churches may be one possible explanation to the growth of these denominations, but others have cited much larger structural changes.

Gill (1999) and Iannaccone, Fink, and Stark (1997) have espoused market explanations for the growth of Evangelical Protestantism and Pentecostalism in terms of supply and demand side explanations. The demand side explanation simply states that 
the failure of Progressive Church to ease the burden on people experiencing major social and economic dislocation has lead to an increase in demand for religious and associational activities, especially for non-traditional faiths.

The supply side explanation asserts that increased growth in religious activities is a direct result of an increased supply of religious goods. The decrease in restrictions on religious activity results in a decrease in costs to religious suppliers, which in turn translates into greater supply (Gill 1999; Iannaccone, Fink, \& Stark 1997). When a religious monopoly is in place, the priority of that religion is retaining membership among the wealthy or status quo for their financial backing necessary to maintain the institution. As states deregulate religious activities, competition increases, making more room for denominations where membership becomes the priority over finances. In short, as new denominations enter the religious market place they tend to use membership as a means to establish their place in society (Gill 1999; Innacone, Fink, \& Stark 1997).

For Lancaster (1988, p. 104) conversion to Protestantism has been triggered by the same stimuli that led to the growth of Liberation theology. Lancaster makes this assertion on the basis that adherents in both forms of religion come from the same low to middle class socioeconomic backgrounds and complain about the same problems of crime, drugs, poverty, and social disorganization. Both Progressive Catholicism and Evangelical Protestantism are organized at the barrio level and provide social organization whereby adherents of each of the faiths interact with those experiencing similar problems, creating a common social bond and an outlet for addressing social issues. 
Pentecostalism has been one of the biggest religious movements filling the religious void. Founded by Charles Parham in Topeka, Kansas and at the Asuza Street Missionary in Los Angeles, California (Cleary 1997, p. 9; Chestnut 1997, pp. 25-26) Pentecostalism's greatest theological achievement in Latin America is the freedom of expression and the affirmation of the individual's worth within the community. Willems (1967) and D’Epinay (1968) claim that Pentecostalism offers institutional structures and practices that help people navigate the present, baffling, threatening world (Chestnut 1997; Gill 1999; Vasquez 1999). Though Latin American Pentecostalism remains Biblically literalist and individualistic, even believing that inclusion in the political arena is defiling, they are beginning to make inroads into politics. This is evident from the election of Evangelical political figures throughout the region. For example, in 19901991, twenty-two Evangelical Congressmen, some Pentecostal, took office in Guatemala along with Jorge Serrano Elias, the country’s first Evangelical President (Gill 1999; Daudelin and Hewitt 1995; Stoll 1990).

Pentecostalism and Evangelical Protestantism are similar some distinct doctrinal differences do exist. Pentecostals is a Protestant religious movement emphasizing the “gifts of the Holy Spirit” (Chestnut 1997; Stoll 1993). Pentecostals believe in “sanctification” or that a true believer can reach Christ's perfection on earth, as well as a belief in being rebaptized in the name of Jesus only. Evangelical Protestants on the other hand believe that Jesus died for their sins and thus cannot replicate Jesus' life. The difference in these beliefs means that Pentecostals are more likely to be otherworldly and believe in such things as speaking in tongue and faith healing. 
While these outward political activities demonstrate the growing prominence of Evangelical Protestantism and Pentecostalism in the region, it is within their communities and churches where interpersonal trust begins to develop, affecting civil society and politics. Chestnut (1997, pp. 11-24), in his look at Pentecostals in Belem, Brazil, finds that it is predominantly occupied by the poorest of the poor. Pentecostalism appears to have begun as a women's movement as they attempted to cope with the alcoholism, tobacco use, drugs, and marital infidelity of their spouses that accompany machismo attitudes (Chestnut 1997, pp. 11-24; Cleary 1997, p. 18). The Pentecostal and Evangelical Protestant belief in abstinence has been proven to be an effective mechanism for combating alcoholism (Gorsuch 1995, pp. 65-80). Though Pentecostal women are not “feminists", the conversion experience does increase women’s autonomy and undermines traditional machismo attitudes (Mariz and Machado in Cleary 1997, pp. 4142).

Pentecostalism and Evangelical Protestantism allow women more ability to enter the micro-entrepreneur sector. According to Chestnut 1997, pp. 116-117) Evangelical and Pentecostal women see poverty as the “...hands of Satan”; thus they are able to enter in to the workforce washing clothes, baking cakes, or creating other small enterprises where they help their families escape poverty. These micro-entrepreneurial businesses also allow women to be self-employed, setting their own schedule and thus permitting their true dedication of time towards God and their particular church.

Money saved by the abstinence from drugs and alcohol allows some Pentecostal and Evangelical Protestant adherents further interclass upward mobility and some ease from their impoverished situation. Pentecostalism and Evangelical Protestantism have 
also become safe havens and places for community interaction and job referrals for those making the shift from rural to urban settings. It helps them to establish themselves in this rugged, complicated and baffling new world (Martin 1990; Stoll 1993; Chestnut 1997). In cases of dire poverty, the belief in faith healing has provided adherents with alternatives to inaccessible medical care.

Campos (1996, pp. 42-45) sums up the effects of Pentecostalism by stating it provides meaning to everyday life, gives power to the weak, and even provides social identity. Pentecostalism and Evangelical Protestantism's autonomous financial structures, focus on Latin American liturgy, and popular expressions of religiosity have created a community experience that affirms individual worth and permits adherents a role in society. Combined with its provision of solidarity with the less favorable sects of society, Campos (1996, pp. 48-49) believe it will, in the end, change civil society.

Pentecostalism and Evangelical Protestantism alter the civic identity of the individual. The individual becomes part of a community that includes others under similar duress and gives adherents power to work together in finding solutions. The religious forms of Evangelical Protestantism and Pentecostalism may alter civil society by establishing communities that form interpersonal trust and empower adherents to be more active in the political system. One can argue that Evangelical Protestantism and Pentecostalism “....may be one of the new social movements that are defining the parameters of democracy ... the very boundaries of what is properly defined as the political arena: its participants, its institutions, its processes, its agenda, and its scope (Alvarez et al 1998, p. 90)”. Patterson (2004, pp. 356-357) claims that Evangelical Protestant adherents in Latin America are not necessarily more democratic in attitudes 
than Catholics but appear to be composed of common citizens and therefore are not an obstacle to democracy.

\section{The Case of Nicaragua}

Central America provides a fertile ground for the study of civil society, religion and democracy. The region as a whole has suffered waves of dictatorial regimes, military regimes, Marxist uprisings, and failures at democratic consolidation. Nicaragua itself has

endured three generations of a dictatorial regime under the Somozas and eleven years of a Marxist movement led by Daniel Ortega under the auspices of the FSLN until its most recent democratic transition in 1990. The Roman Catholic Church has been the major contributor to civil society throughout Nicaragua’s tumultuous political history. The Catholic Church, in all of its forms, has had a profound effect on shaping Nicaraguan society: From legitimization of the Somoza dictatorship by the Traditional Roman Catholic Church, to providing the organizational capacity and religious justification for the Sandinista insurrection by the Progressive Church, and finally as the primary provider for associational activity in this newly democratized state.

To provide a base line understanding of Nicaragua’s political and historical development Figure 2-1 provides a timeline of significant historical events. 
Figure 2-1: Historical Timeline of Nicaragua

\begin{tabular}{|l|l|}
\hline \multicolumn{1}{|c|}{ Date } & \multicolumn{1}{c|}{ Event } \\
\hline 1838 & Independent Nicaragua established. \\
\hline 1856 & $\begin{array}{l}\text { American William Walker, hired by Cornelius Vanderbilt, briefly } \\
\text { assumes control of Nicaragua. }\end{array}$ \\
\hline $1909-1933$ & U.S. Marines occupy of Nicaragua \\
\hline 1927 & César Agusto Sandino leads five year uprising against U.S. Marines \\
\hline 1934 & $\begin{array}{l}\text { General Anastasio Somoza García assassinates Sandino and overthrows } \\
\text { President Juan Batista Sacassa, and takes over the government }\end{array}$ \\
\hline 1956 & $\begin{array}{l}\text { General Anastasio Somoza García is assisinated and succeeded by his } \\
\text { oldest son Luis Somoza. Dies four years later of a heart attack and } \\
\text { replaced by a puppet president. }\end{array}$ \\
\hline 1960 & $\begin{array}{l}\text { The Frente Sandinista de Liberación Nacional (FSLN) is founded in } \\
\text { protest to the Somoza regime }\end{array}$ \\
\hline 1967 & $\begin{array}{l}\text { General Anastasio Somoza Debayle, youngest son of General } \\
\text { Anastasio Somoza García, becomes president. }\end{array}$ \\
\hline 1972 & $\begin{array}{l}\text { Most of Managua is destroyed by earthquake at 12:27 AM on } \\
\text { December 23, 1972 }\end{array}$ \\
\hline 1978 & $\begin{array}{l}\text { Assassination of Pedro Joaquín Chamorro, editor of } \text { La Prensa } \\
\text { newspaper, blamed on Somoza, sparks several days of strikes and } \\
\text { boycotts. }\end{array}$ \\
\hline 1979 & Sandinistas (FSLN) oust Somoza who flees on July 17 \\
\hline 1981 & Contra attacks begin. \\
\hline 1984 & $\begin{array}{l}\text { Sandinista leader Daniel Ortega is officially elected President for a six } \\
\text { year term. }\end{array}$ \\
\hline 1990 & $\begin{array}{l}\text { Violeta Barrios de Chamorro, wife of Pedro Joaquín Chamorro, defeats } \\
\text { Daniel Ortega in Presidential elections. }\end{array}$ \\
\hline 1996 & Former Managua mayor Arnoldo Aléman is elected president. \\
\hline 2002 & $\begin{array}{l}\text { Nicaraguan businessman Enrique Bolaños is elected president. } \\
\text { Arnoldo Aléman is charged with money laundering and embezzlement } \\
\text { during his presidency. }\end{array}$ \\
\hline 2002 & $\begin{array}{l}\text { Arnoldo Aléman is convicted and sentenced to 20 years in prison, } \\
\text { which has since been reduced to house arrest by Enrique Bolaños. }\end{array}$ \\
\hline Wo2 & W \\
\hline
\end{tabular}

Sources: Wynia, Gary W. The Politics of Latin American Development, $3^{\text {rd }}$ Edition, Cambridge University Press, 1990 p. 310 and Walker, Thomas Nicaragua: Living in the Shadow of the Eagle, $4^{\text {th }}$ Edition, 2003, pp. 25-77.

Prior to the 1960s the Traditional Roman Catholic Church in Nicaragua had continually been a source of legitimization for the Somoza regime (Sabia 1997; Kirk 1992; Mulligan 1991; Lancaster 1988; Belli 1985). From the 1930s to the 1960s, Kirk (1992, 48) claims the Traditional Church “deliberately” sought to protect the Somoza 
regime in exchange for favorable treatment from the elite class. In turn, the Traditional Roman Catholic Church produced a secondary social doctrine where socioeconomic dislocation could only be overcome through prayer and patience. To resort to other methods was to reject divine will. A pastoral letter from Archbishop Fonalez y Robleto in August 1959 demonstrates that the body of pastoral care directed at Nicaraguan Catholics was a clear attempt to convince them unquestioningly to accept the Somoza administration as the legitimate constitutional government (Kirk 1992, p. 49).

Lancaster (1988, p. 29) explains that in peasant-based societies religious elites are instruments of the ruling elites, legitimizing ruling class power, because in these societies religious and ruling elites are in continuous interaction with one another. Almost invariably elites adhere to traditional and conservative Catholicism, which posits spiritual and moral authority in the established offices of the Traditional Church. Therefore, the message of elite religion is to proclaim the justness and wisdom of the ruling class. Nicaragua is no exception, as the major diverging points of religious belief correspond to socioeconomic strata. The elites tend to adhere to the Traditional Catholic Church, and as one moves down the socioeconomic continuum Catholicism undergoes a series of transformations to Liberation Theology and even on to Charismatic Catholicism and Evangelical Protestantism (Lancaster 1988, pp. 27-29). The idea that changes within the Nicaraguan Catholic Church started at the grass roots level should come as no surprise. The bishops and upper clergy mixed with the privileged sectors of society while the priests and religious laity lived along side of the impoverished masses (Kirk 1992, pp. 6667) 
At the heart of Traditional Roman Catholic Church policies was an effort to protect the Church as an institution. The desire to protect the Traditional Church remained even after the Church changed its position toward the Somoza regime, which came about in the 1970s when the Traditional Roman Catholic Church bravely took on the dictator (Kirk 1992, p. 84; Sabia 1997, p. 62). Change in the Church’s stance was a direct result of the updated church doctrine coming out of Vatican II and the CELAM in Medellin, Columbia, in the early 1960s. These events produced a Traditional Roman Catholic Church more responsive to the needs of the disadvantaged through an adoption of the “preferential option for the poor” (Kirk 1992; Sabia 1997; Lancaster 1988; Belli 1985)

In Nicaragua the Traditional Roman Catholic Church was slow to adopt the changes encompassed in Vatican II and CELAM. The impetus for change occurred in Managua in January and February of 1969 at the "Encuento Pastoral”. The three central themes for the deliberations were the nature of the Catholic Church in Nicaragua, the role of the Roman Catholic Church, and an analysis of the sociopolitical reality of contemporary Nicaragua. The “Encuento Pastoral” became a debate between conservatives of the aging hierarchy and more liberal clergy. Criticisms of the Traditional Roman Catholic Church included a lack of true spiritual leadership; a lack of dialogue and distance from concerns of the faithful, lack of social justice commitment; a formalistic ritualized approach to Catholic catechism, and excessive fees shared by parish priests for religious services. With criticisms of the Nicaraguan Traditional Roman Catholic Church in mind, the Vatican decided in late 1970 to install a leader without close ties to the Somozas to revive sagging Church moral. Miguel Obando y Bravo was 
appointed Archbishop of Nicaragua. Obando y Bravo rejected attempts to be co-opted by the Somozas, and leading up to the revolution, served as intermediary between the Somozas and the FSLN. The relationship between the Sandinistas and Obando y Bravo soured shortly after the revolution as a result of differing ideas about the role of the Church in Nicaraguan society (Kirk 1992, pp. 52-64).

These events are noteworthy because they signify the changing of church - society relations and provide the necessary ingredients for the growth of the Progressive Church. For example, it was not inconsequential that the founding of the FSLN coincided with the opening of Vatican II. The climate arising from Vatican II helped to foster the conditions favorable for future relationships between the Progressive Church and the Sandinistas (Sabia 1997, p. 55).

The Sandinista revolution was successful because of cross-class cooperation and movement (Everingham 1996, p. 4, Kirk 1992, pp. 60-62). Kirk (1992, pp. 60-62) attributes this cooperation to three factors. First was the popular reaction to the devastating 1972 earthquake, which left 10,000 dead and a quarter of all Managuans homeless. Dissatisfaction with the regime was a result of the diversion of relief funds from the bourgeoisie and middle classes to Somoza personally. Second was the gradual development of a diverse societal opposition, from peasant groups to elites, which had either been co-opted by Somoza in the past or had developed some reason to wish for the end of the regime. Both of these factors were intensified by unfair business practices resulting from Somoza's virtual control over the nation. For example, making campaign contributions and paying some bribes were simply part of usual business practices and widely accepted. However, the transfer of so much relief money away from the middle 
classes, coinciding with the steady growth in economic marginalization, drew support away from Somoza in the elite classes.

The third factor was the growth of the FSLN movement, strengthened through the exposure they received by seizing the house of a close associate of Somoza during a 1974 Christmas Party attended by U.S. ambassador Turner Shelton and the mayor of Managua, Somoza's brother in law. The FSLN forced Somoza to release political prisoners, including the future FSLN President of Nicaragua Daniel Ortega, and to publish the FSLN manifesto. These actions demonstrated to the rest of Nicaraguan society that Somoza was not invulnerable. The growth of the FSLN was also assisted by the growth of the Progressive Church through the creation of Christian Base Communities (Kirk 1992).

Kirk (1992), Sabia (1997), and Lancaster (1988) all attribute the growth of the FSLN to the explosion of the Progressive Church through Liberation Theology. The formation of the Progressive Churches provided the FSLN with a network through which Church members could participate directly by becoming members of the FSLN or passively by providing its members with safe houses, food, and other supplies. Through this sort of participation, they often became targets of National Guard terror. This influenced once passive members to militate against these human atrocities and confirmed the beliefs of more militant participants (Sabia 1997, p. 65). It is this religious foundation of a revolutionary movement through associational activities that makes a study on the affect of religion and civil society in Nicaragua compelling.

In order to understand the role of popular or progressive religions of the poor, one must note the characteristics that differentiate it from traditional or elite religions. The 
Progressive Catholic Church and Traditional Roman Catholicism are all part of the same system and thus share some views. However, they are also distinctly different because in "popular" or "progressive” forms the poor interpret the meanings of religious doctrine from their point of view. For example, the Liberation Theology practiced in the Progressive Church emphasizes class struggle as the key to the Kingdom of God while Evangelical Protestantism posits that the key is the individual (Lancaster 1988, p. 31, p. 96).

Evangelical Protestantism is the most competitive religion for Progressive Catholicism in Nicaragua, especially in the poorest barrios (Lancaster 1988, p. 101). Evangelical Protestantism and Progressive Catholicism have been extremely important for civil society in Nicaragua. They have a similar demographic configuration, supported by the poor and middle classes, and have been creators of normative communities. Both religions see a link between wealth and sin. Progressive Catholicism claims that wealth separates man from community and God while Evangelical Protestantism's focus on the individual means that wealth takes away from spiritual pursuits of the individual. Progressive Catholicism produces normative communities through the structure of CEBs, while Evangelical Protestantism has created communities through the concepts of evangelical deeds or good works (Lancaster 1988, pp. 111-115). This link has played a significant role in the associational activities undertaken by their adherents. The question becomes, do these differing associational activities, though linked, produce the same forms of civil society?

Sabia (1997) conducted a study on the development of popular religions and the revolutionary movement in Nicaragua and created a four-part typology based on the 
affect of popular religions and revolution on the individual. The first of Sabia's religious types is the "Marxist Type". The Marxist Type is distinctive in two ways. First , these individuals accept Marxism as their political ideology. Second, although some still consider themselves member of CEBs, they no longer consider themselves to be Catholic or even Christian in the traditional sense. Their motivation is purely political, rejecting any type of religion and viewing religion as an alienating influence in human society (Sabia 1997, pp. 96-97). Politically, they speak of the weaknesses of liberal democracy, claiming that the right to vote is neither sufficient nor necessary to ensure poor peoples' equality. The Marxist Type remains dedicated to the Sandinista movement and is negative toward religious figures, often referring to clergy as Judases. Though they appear nonreligious, they often speak in spiritual terms (Sabia 1997, pp. 105-109).

The second part of the typology is the "Revolutionary Christian Type". Like the "Marxist Type", these individuals accept the notion that there are obstacles to human development. They were won over to the Sandinistas by the idea of class struggle and tend still to support them, as well as remaining members of CEBs. The Revolutionary Christian Type differs from the Marxist Type in that they have not had a deChristianizing experience and speak of their political commitment to social justice as a consequence of their faith and Liberation Theology, which continues to motivate their political activity. The Revolutionary Christian Type's political motivation is a logical outgrowth of their growing social consciousness, the themes of liberation theology, and acceptance of the Sandinista historical project. According to Sabia, it is typical to hear them speak of "God as the liberator of the poor and the role of Christ as a political revolutionary". Revolutionary Christians regard their active service to the community as 
taking priority over their devotion to the local church but openly regard themselves as Catholic (Sabia 1997, pp. 116-132)

“The Reformist Christian Type” members of the Progressive Church have more secular motivations. Reformists suggest that while the interpretation of Christianity in Latin America may have facilitated greater consciousness of social justice, it was the overt corruption of the regime and economic crises that inspired their involvement in the insurrection. As a result they only tenuously supported revolutionary reforms of the 1980s. Reformists are highly critical of an ideology that defends one class over another and reject the idea that society can be changed from the top down. Reformists argue that the work for change must occur at the civic level through the maturation of Christian consciousness, which means creating a new person in Nicaragua. Reformists are more likely to be engaged in religious and educational activities in their neighborhoods. Whereas they appear to be politically cautious, they also support popular organizations that they perceive are working for a more democratic, equitable, and socially just society (Sabia 1997, pp. 144-147)

Finally, the "Alienated Christian Type" includes wealthy members of Nicaraguan society, some poor and middle class Nicaraguans, critics of the Traditional Roman Catholic Church and Progressive Churches, and opponents of the Sandinistas. Many are former Catholics, former members of CEBs, and early Sandinista supporters. Like Reformists they claim that social and economic crises explain the anti-Somoza insurrection. In the 1980s Reformists became disaffected with the Progressive Church and departed. Reformists view the Progressive Church as a political organization with separate practices and doctrine from the traditional Roman Catholic Church. Alienated 
Christians appear not to believe in a preferential option for the poor and believe poverty is a natural part of the world. Sabia finds that Reformists are most likely to convert to Evangelical Protestantism and Charismatic Catholicism (Sabia 1997, pp. 173-209).

Sabia's typology is significant because it makes a strong connection between religion, civil society, and government. The religion practiced within the Progressive Church greatly influenced the worldview of adherents by providing an understanding of the relationship between government and society. These are normative in nature, but it is the primary way in which people view the outside world, government institutions, and society as a whole. The associational activities undertaken by each type tend to produce different outcomes. The Marxist Type and Revolutionary Christian Type look to be producing a civil society supportive of socialism as espoused by Marxist principles, while the Reformist and Alienated types appear to be producing a civil society supportive of democracy.

In the years since the democratic consolidation (1990) under President Violetta de Barrios Chamorro, the Progressive Church in Nicaragua has been dwindling in both numbers and activism. The poor organizational structure of CEBs, their close association with the FSLN, and the FSLN's poor conduct damaged the Progressive Church in Nicaragua (Deonandan 2001, pp. 451-452). In its final years in government, the FSLN was accused of corruption and criticized for implementing financial policies that countered their Marxist vision. This led to their defeat in 1990, and also in 1996 by Armando Aléman, who actually had supporters of the Somoza regime campaigning on his behalf, and again in 2000 with the ascension of Liberal Constitutional Party (PLC) candidate Enrique Bolaños to the Presidency. Furthermore, the leadership and direction 
of the Progressive Church has been in decline, and the Traditional Roman Catholic Church has been reasserting its power and de-legitimizing the CEBs (Deonandan 2001; Williams 1992).

These events have implications for civil society, as cross nationally traditional Roman Catholicism has been associated with theological conservatism. In Nicaragua this conservatism has become evident in some of the Traditional Roman Catholic Church's contemporary public policies. Economic and employment policies are pushing women back into the home, which Deonandan (2001, pp. 454-455) claims are a policy of both the Traditional Roman Catholic Church and the Nicaraguan State. This is important for the health of civil society, especially as it relates to the viability of democratic institutions. As Casanova (2001, p. 1044) points out, the Roman Catholic Church can only be considered a civil society actor as long as it remains outside the state. If it works in concert with the state, it then becomes part of the state, and these new policies put its independence in question.

Concurrent with the demise of the Progressive Church and rebirth of the Traditional Roman Catholic Church, Evangelical Protestants and Pentecostals have taken hold. The latest census conducted in 1995 in Nicaragua states that 72.9 percent of the population belong to the Roman Catholic Church in all of its forms, 15.1 percent were members of Pentecostal and Evangelical churches, 1.5 percent belong to the Moravian Church, 0.1 percent belong to the Episcopal Church. Other Christian denominations, including Amish and Mennonite communities, the Church of Jesus Christ and the LatterDay Saints (Mormons), Jehovah’s Witnesses make up 1.9 percent with 8.5 percent claiming no religious affiliation (US Dept of State 2001 
http://www.state.gov/g/drl/rls/irf/2002/14052.htm). Today, Traditional Roman Catholicism

remains the largest religion in Nicaragua.

Two studies of Protestant movements have found that the stereotypical assumptions that Pentecostalism and Evangelical Protestantism lead to conservatism appear not to hold in Nicaragua. Lancaster (1988) and Smith and Haas (1997) have studied the Evangelical Protestant and Pentecostal movements in Nicaragua and found that politically they appear to be much less conservative than previously thought. They found that adherents to these denominations are just as likely to support revolutionary action as others with similar demographic background. Evangelical Protestants and Pentecostals form communities of underprivileged and working class people; thus, if the policies of the revolutionary government can help these communities, they are just as easy to court as Catholics (Smith and Haas 1997, pp. 446-450). In terms of civil society, this demonstrates that the associational activities of Evangelical Protestants and Pentecostals in Nicaragua form communities through which they enter into political action to have their demands met. Therefore, an exploration of how this affects civil society as a whole, may go a long way in helping us understand the depth of the democratic movement currently establishing itself in Nicaragua.

As has been illustrated from this overview of religious development in Nicaragua, traditional religious institutions have fragmented and new religious institutions have taken hold. For Sabia (1997), participation in the popular churches has produced different types of individuals and orientations toward the role of government in society. Lancaster (1988) and Smith and Haas (1997) have demonstrated that the Evangelical Protestant religions are not as conservative as previously believed and these churches are 
producing communities capable of coming together for political action. To move forward with this research, an understanding of how civil society is affected by religious affiliation and religiosity is imperative. 


\section{Chapter Three}

\section{Questions and Hypotheses}

This micro-cultural study of Nicaragua's densely populated Central Pacific region is not an attempt to make a direct causal correlation between religion and democracy, nor between civil society and democracy. It is simply asserting that civil society is an important variable in the establishment and maintenance of democratic institutions and religious institutions are central actors within civil society. Therefore, the research is exploring whether distinct religious forms or denominations create diverse forms of civil society, of which some forms may be more capable than others at producing attitudes and beliefs capable of maintaining democratic institutions. It also explores the effects of religiosity, or the level a respondent uses religion as a guide to everyday life, on civil society participation.

Religion is a cultural phenomenon. Inglehart (1988, p. 1204) claims that societies are politically influenced by their cultural attitudes. These attitudes are enduring but not immutable. As the input for civil society changes from Traditional Roman Catholicism to Evangelical Protestantism and Pentecostalism, then so, too, will inputs for civil society. As these forms of civil society become more codified, the political culture will also change.

To implement this study, a number of research questions and hypotheses have been generated. The central question is to what extent do various religious structures, practices, and orientations produce different forms of civil society? Are some religious denominations, and the specific associational activities encompassed within them, better at producing a civil society capable of establishing and maintaining democratic 
institutions than other religious forms? More specifically, do Evangelical Protestantism and Pentecostalism, because of their role in redefining community and creating a safe haven from the hardships of every day life, produce a civil society better at maintaining democratic institutions than either Traditional Roman Catholicism or Progressive Catholicism? Does Traditional Catholicism, because of its hierarchical structure and mediated relationship with God, create a civil society conducive to authoritarian forms of government? Does Progressive Catholicism, as born out of Liberation Theology and structured in CEBs, create an anti-regime civil society illustrated by the definition of Civil Society II?

This research differs from previous studies of civil society and democracy in Central America by focusing on religious institutions as central figures in civil society. The goal is to understand the effects of religion on the individual's propensity to participate in civil society and with other civil society actors rather than simply exploring religion as one small civil society actor among many. Religion is of growing concern as a major source of conflict and the basis for governance in many regions of the world, especially when two different religions, such as Islam and Christianity, come into contact with one another. According to Huntington (1997) conflicts based on cultural and religious entities are the "fault lines" dividing the world today. This study intends to understand whether this relationship exists between different forms of the same religion creating a "fault line" in the establishment and maintenance of domestic political institutions and support for democracy. Does the current mix of religions in Nicaragua favor a democratic or authoritarian domestic political structure? Will there be a decline in the democratic regimes in the region and can religion be a predictor of political decay? 
To help answer these complex and important questions a number of hypotheses have been generated.

H1. Pentecostalism produces a civil society capable of establishing and maintaining democratic institutions.

This hypothesis is derived from the literature produced by Chestnut (1997), Cleary (1998); Stoll (1990); Vasquez (1999); Gill (1999); and others who espouse that Pentecostalism and Evangelical Protestantism provide communities that ease the burden of an uncertain world and an escape from daily life in the region. These communities help adherents deal with social problems such as alcoholism, drug abuse, and adultery associated with machismo (manliness) attitudes by providing a community experience that endows adherents with a role of worth in their community. They provide opportunities for upward social mobility through money saved out of abstinence from vices. The communities also endorse the entrance of women in the micro-entrepreneurial sector and encourage solidarity with the less favorable classes. Furthermore, their independent structures from both the state and their sister denominations, as well as being based on "survival strategies" for Latin Americans shows that these religions are forming communities that help produce interpersonal trust and social capital. The survival strategies undertaken by these independent churches exemplify hope to the individual in a complicated and often harsh environment and provide a successful route to follow.

H2. Evangelical Protestantism produces a civil society capable of establishing and maintaining democratic institutions.

According to Stoll (1990, p. 4) differentiation between denominations can be a daunting task because of their independent forms. Stoll uses "Evangelical” to denote all non-Catholic Christians. Stoll admits that within the United States this term “...connotes 
a theological conservatism with emphasizes on the Bible, personal salvation, and evangelism.” However, in Latin America the term is less restrictive in its use. In Latin America, Evangelical Protestant and Pentecostal Churches are independent from their sister denominations abroad both financially and structurally. Their independence means they are not as polarized along theological and political boundaries as are many of their sister denominations in the North. To then separate religious institutions by denomination in studying their effect will negate the religious effects on civil society that cross cut these formal boundaries (Stoll 1990, pp. 3-13). For the purpose of this study, it is worthwhile to explore whether associational differences between Evangelical Protestantism and Pentecostalism produce different forms of civil society.

H3. Traditional Roman Catholicism produces a civil society less capable of establishing and maintaining democratic institutions.

Huntington (1991), Lipset (1994), and Casanova (2001) all state that Traditional Roman Catholicism has conventionally engendered a negative relationship with democracy because of its hierarchical structure and its large number of impoverished adherents. Huntington's (1991) third wave of democratization consisted mainly of Catholic countries and was a result of internal changes within the Roman Catholic Church, accompanied by relative economic success among Catholic dominated countries (Huntington 1991, pp. 75-80). However, other scholars (Casanova 2001; Deonandan 2001) have found that the Traditional Roman Catholic Church still upholds its role in the maintenance and legitimacy of the status quo for the wealthy and upper classes. Casanova (2001, p. 1044) claims that the Traditional Roman Catholic Church can be a source of civil society, in as much as it is independent of state power. In cases where the 
Traditional Roman Catholic Church has maintained its dominance, it is much less an exemplar of civil society, but part of the state. Today in Nicaragua the Traditional Roman Catholic Church may be reasserting itself in society through the state, as is indicated from Church endorsed employment policies encouraging women out of the workforce and reasserting the woman's traditional role as homemaker (Deneonandon 2001, pp. 454-456). Traditional Roman Catholics are more conservative across issues, which translates into low levels of trust in subordinate classes. Thus, in terms of adding to civil society Traditional Roman Catholicism will be negative for the production of democratic civil society.

H4. Progressive Catholicism, as espoused by Liberation Theology, produces a civil society less capable of establishing and maintaining democratic institutions.

Progressive Catholicism will have an overall positive affect on civil society. However, the form it will create will be more reminiscent of Civil Society II or antiregime civil society. Progressive Catholicism will demonstrate greater characteristics of civil society I than Traditional Roman Catholicism, but less than Evangelical Protestantism and Pentecostalism. Progressive Catholicism, as practiced in Nicaragua, was founded on Marxist principles under the duress of the Somoza dictatorial regime. As a result of these circumstances, Progressive Catholicism will engender negative associations with formal civil society and confidence in political institutions by exhibiting more revolutionary tendencies and distrust of formal organizations. As the motivating factor behind Progressive Catholicism, a repressive dictator like Somoza, disappears, so, too, will the motivation of adherents to fight for the social justice issues espoused by Progressive clergy and lay people. Though social justice is not achieved by the deposing of a dictator like Anastasio "Tachito" Somoza Debayle, the main obstacle to 
social justice is removed. Once this occurs, the movement fragments as different adherents and clergy are now free to pursue their own vision of social justice.

H5. Charismatic Catholicism produces the most capable civil society for establishing and maintaining democratic institutions among the Catholic Denominations.

Charismatic Catholicism appears to be a mix between the doctrine of Traditional Catholicism and the communities and practices formed through the Pentecostal and Evangelical Protestant denominations. Charismatic Catholicism is a religion of the middle classes built out of a rejection of the socialist ideals of Progressive Catholicism and the legitimacy of the status quo of Traditional Roman Catholicism. Though it looks to be modeled after the Evangelical structure, it is hypothesized that because it has been built out of a rejection of politically motivated religious practices of both the Traditional and Progressive Catholic Churches, it will be the least politically active and most inward focused of all religious denominations. Therefore, the role of Charismatic Catholicism in civil society should be muted because of its outright rejection of politics, irrespective of its similarities to Evangelical Protestantism and Pentecostalism. Charismatic Catholicism may also be conservative across issues as their doctrine remains Catholic. However, Charismatic practices and churches are similar to Evangelical thus they may act more like Evangelicals in civil society, but with less of an impact.

\section{Methodology}

To collect the data for this research a survey instrument was developed measuring the political attitudes of 602 Nicaraguan respondents to determine how their associational activities create a civil society capable of sustaining and maintaining democratic 
institutions or Civil Society I. Surveys were conducted February through June 2003, in Granada, Managua, Masaya, and the Pueblos Blancos areas of Nicaragua.

The residents of Granada claim is the oldest city in the western hemisphere and traditionally has been the stronghold for conservatives throughout Nicaragua's tumultuous political history. Francisco Hernandez de Cordoba founded Granada in 1542 and Nicaragua’s currency has been named for him. ${ }^{1}$ The 98,600 (www.worldgazeteer.com) residents of Granada are socioeconomically diverse, with some living in beautifully maintained and brightly colored colonial houses on Calle Alcazada, and others in small sparsely constructed dwellings in barrios like El Estación. Granada is one of the most popular cities among tourists due to its colonial setting and accessibility to such attractions as Volcán Mombacho and its cloud forests, Lago de Nicaragua, and La Isletas. This has given a boost to many impoverished residents working in the microentrepreneurial sector such as selling juices, chic-lets, nuts and fruits, and providing carriage rides. Working class Nicaraguans such as taxi drivers, boat drivers, and restaurant owners also thrive in this blossoming tourist economy. ${ }^{2}$

Masaya is situated directly between Granada and Managua and has a population of around 122,200 (www.world-gazeteer.com). Masaya is known for its large market place, one of the largest in Nicaragua and one of the most popular among Nicaraguans and tourists alike, and its series of volcanic lakes sitting on either side of the city. As one of Nicaragua's larger cities, it engenders socioeconomic diversity but it is less extreme

\footnotetext{
${ }^{1}$ One of the signs entering the city states that Granada was discovered in the 1542 and claims it is the oldest city in the Western Hemisphere.

2 Neighborhoods in Granada represented in the survey are: Colonia Alvarado; Pueblo Chiquito; Palmira; Calle Corrales; Julian Guintana; Bartolome; Rosario; Calle la Libertad; Trabajista; Estación; Calle Cieba; 14 de Septiembre; La Isleta; Colonia Alvarado; Calle Tamarindo; La Concepción; Mirra Laguna; Calle Guzman; Calle San Juan del Sur; Calle Alcazada)
} 
than the disparity between rich and poor found in Granada. Masaya is also not considered to be as strongly partisan as Granada or León, but probably is a little more leftist than Granada, given the vast numbers of statues and memorials dedicated to the FSLN found throughout the city.

The Pueblos Blancos are a series of mountain towns known for having a white cathedral in the square of each town. ${ }^{3}$ The Pueblos Blancos are rich in culture and history as the birthplace of Augusto César Sandino, an early revolutionary and the symbol of the Sandinista movement. The area is known for being sympathetic to the FSLN. These towns average from a few hundred residents to a few thousand. Catarina is known for its plant vendors and San Juan Del Oriente for its artisans.

Nicaragua's capital Managua is the largest city in the country with a population of around 1,440,500 (www.world-gazeteer.com $)^{4}$. Managua is by far the largest and most socioeconomically diverse city in Nicaragua. It is the center of government and exemplifies polarization, with neighborhoods ranging from the wealthiest Nicaraguans such as Los Robles to the many squatter camps and shantytowns dotting the city. Leveled by the tragic 1972 earthquake that killed more than 10,000 Managuans and left more than 300,000 homeless, it is a confusing city with poor infrastructure and few street signs or markers. Addresses in Managua are given in blocks away from some arbitrary landmark (Ross 2002; Bohning 1998). A single neighborhood will have different names depending on whether the respondent uses the name under the FSLN, the pre-

\footnotetext{
${ }^{3}$ Towns in the Pueblos Blancos area where the survey was conducted: Diriá; San Juan Del Oriente; Naindaime; Diriomo; Catarina; Ninquinohomo; Nindirí

${ }^{4}$ Barrios in Managua where the survey was conducted, these barrios are very large and mainly working class, El Jardín is the wealthiest neighborhood of the three: 14 de Juneo; El Jardín; Maximo Jerez
} 
revolutionary name, or the current one. ${ }^{5}$ The Carretera de Masaya has become the most modern section of Managua, with newly constructed hotels and modern shopping centers. Managua is also the center of culture with universities such as the National Autonomous University Nicaragua (UNAN) and the Universidad Centroamericana (UCA) as well as a number of museums, theaters, and nightlife. ${ }^{6}$

The surveys were face-to-face interviews lasting anywhere from 15 minutes to well over an hour. Each respondent was over the age of 18 at the time of the survey. The surveys were read in Spanish to the respondent with the aid of a research assistant and each respondent was provided with placards indicating possible responses. To maximize validity surveys were taken at every fifth house. ${ }^{7}$ Many Nicaraguan dwellings are small in size and may only consist of one or two rooms with many residents, thus privacy and influence from others in proximity to the interview means that interference may be a problem.

\section{Variables}

The dependent variable, Civil Society I, is derived from the definitions provided by Booth and Richard (1998) and Brysk (2000). Civil Society I is defined as associational activity outside the state that produces beliefs and attitudes conducive to the viability of democratic institutions. Civil Society II is defined as associational activity that tends to be conflictual and anti-tyrannical which encourages resistance to the current regime. Civil society III consists of those forms of associational activities that encourage

\footnotetext{
${ }^{5}$ The author of this research lived in a neighborhood in Managua in 1995 named Barrio La Luz or 14 de Juneo (FSLN name). When navigating the city via taxi it was extremely important to know both names. ${ }^{6}$ UNAN is the largest public educational institutions and the UCA is a large, private, Jesuit educational institution.

${ }^{7}$ Though attempts were made at every fifth house, the author was not granted permission to conduct the interview at every fifth house. In the process of the fieldwork if the researcher was not granted permission to the fifth house, the survey was conducted at the next available house.
} 
hate, distrust, and discrimination towards specific sectors of society or other civil society providers.

In order to produce quantitative data on Civil Society I, Civil Society II, and Civil Society III as defined above, the concept of civil society is broken down into its individual components and effects. Each component, defined below, is analyzed against a number of independent variables to ascertain which religious forms are carrying out the establishment of a democratic civil society. If Civil Society I outputs are beliefs and attitudes conducive to the establishment and viability of democratic institutions, then it is important to decide what these attitudes are and which are most important.

The composite civil society dependent variable will rely on components from Booth \& Richard (1998), Inglehart (1988), Muller and Seligson (1994), Almond and Verba (1963), and Brysk (2000). Almond and Verba (1963) measure civic culture through a variety of indicators such as attitudes or feelings about government and politics, patterns of partnership and the connections between community and the polity, obligation to participate, civic and political knowledge, and the effects of membership in organizations. Inglehart (1988) measures political culture with indices of life satisfaction, support for gradual or radical change, and interpersonal trust. These measures do not necessarily measure civil society, but they do evaluate the effects of civil society, or at the very least denote the role civil society has for the establishment and maintenance of democratic institutions.

Booth and Richards (1998) measure civil society according to their associational activity modes. The first associational activity mode is formal group activism, which includes affiliation or membership in unions, civic associations, cooperatives, and 
professional groups. The second mode of communal activism denotes affiliation in selfhelp groups and activities at the local level. Booth and Richard (1998) also measure the outputs of civil society by looking at social capital. These measures, based on Putnam's (2000; 1993) concept, include interpersonal trust and political knowledge, as well as political capital levels such as citizen's commitment to democratic norms, including support for gradual change.

\section{Civil Society Dependent Variables}

\section{Formal Civil Society}

The first component of the composite civil society dependent variable, extracted from Booth and Richard (1998), is formal participation in civil society. This variable measures the participation in official organizations such as labor unions, civic organizations, cooperatives or collectives, etc. To operationalize this variable respondents are asked whether they are members of official organizations. The organizations are sports or recreation organizations (FOCSR); arts, music, or educational organizations (FOCAM); labor or trade unions (FOCLU); professional associations (FOCPA); political parties (FOCPP); environmental organizations (FOCEO); and philanthropic or charitable organizations (FOCCP). The respondents are also asked to list other organizations to which they are affiliated.

To gain an understanding of the respondent's level of involvement in formal civil society organizations, they are asked to state their level of participation based on a 5point Likert scale ranging from very active (5) to not a member (1). The scores across all levels of participation and list of organizations were aggregated to create a single score known as the Formal Civil Society Index (FOCIND) which takes into account the 
number of organizations and level of participation in each. The greater the score on the Formal Civil Society Index (FOCIND), the greater the level of participation in formal civil society.

\section{Informal Civil Society}

The second component of the variable, also taken from Booth and Richard (1998), is participation in informal civil society such as self-help organizations or grass roots and barrio level organizations. This component includes membership in various neighborhood organizations and women's organizations as well as informal groups that take part in recreational, volunteer, and community activities. Within the informal civil society a respondent may contribute in two distinct ways, support and participation.

\section{Participation in Informal Civil Society}

Participation means the respondent organizes and attends meetings and activities that work to solve community problems or those of an individual within the community. Respondents are asked to state whether they belong to a community or neighborhood group that works to resolve community issues (IOCCG); whether they have ever donated their work to solve a community problems (IOCDW); whether they have attended a meeting aimed at solving the problems of the community or one of its members (IOCAM); and finally, whether they have ever organized a meeting for the purpose of solving a problem of the community or one of its members (IOCNG). Responses for these questions are "yes (2)" or "no (1)" and include a series of follow up questions to determine whether the problems being addressed through these activities were resolved satisfactorily. These four variables are combined to create an additive index expressing the level of participation of the respondent in the Informal Civil Society Participation 
Index (ICSPIN). On this index a respondent can range from "no civil society

participation, meaning the respondent answered "no" to all four variables to "high civil society participation” if the respondent answered yes to all of the variables.

\section{$\underline{\text { Informal Civil Society Support Index (ICSSIN) }}$}

Informal Civil Society Support denotes the respondents’ participation in associational activities by donating money or sporadic volunteer activity such as spending the day cleaning the street or neighborhood. The Informal Civil Society Support Index (ICSSIN) variable highlights people who support efforts to improve the community or the problems of one of its members by donating money and materials, or who may participate in one large event, but not actively participate implementing a solution. Respondents are asked to indicate “yes (2)” or “no (1)” whether he or she has worked to solve the problem of the community or one of its members (IOCCP) and/or donated money (IOCDM).

Finally, an additive index of the Informal Civil Society Participation Index (ICSPIN) and the Informal Civil Society Support Index (ICSSIN) created the Informal Civil Society Total Index (ICSTIN) an overall variable of informal civil support and participation society in Nicaragua.

\section{Effects of Civil Society Dependent Variables}

To realize the importance of civil society, both formal and informal, for democracy, it is important to explore how participation in civil society affects individual political attitudes and beliefs, thus affecting political culture and the structure and form of political institutions. To implement this, respondents are given a series of questions exploring the concepts of: interpersonal trust, political efficacy, belief in the correctness 
of governmental actions, confidence in governmental institutions, and political knowledge.

\section{$\underline{\text { Political Efficacy Index (POLEF) }}$}

A central component to viability of democracy is the citizen's belief that his or her actions in the political arena affect the overall structure and actions of the government. Fukuyama (1992) claims that the world is embracing democracy out of the basic human need for expression. All history or struggle up until this point has been for the achievement of a political system that permits individual expression. Dahl (1971) states that for democracy to exist people must have the ability to form and articulate demands, the right to organize for the purpose of articulating their demands to those in government, and then have those demands weighted evenly in the conduct of government. Therefore, for democracy to be maintained the citizen must feel that his or her actions influence government or that they are efficacious. Citizens must feel that through their actions they have made their views known.

For this line of questioning respondents are asked to indicate the level of political efficacy by stating their level of agreement on a 5-point Likert Scale where 5 equals “strongly agree” and 1 equals “strongly disagree”. Variables measuring political efficacy are whether respondents feel comfortable asking for the help and cooperation of a member of the National Assemble (PEHNC) and/or the mayor or a representative of the mayor (PEMMO). These variables measure whether respondents believes their demands are weighed in the conduct of government. Respondents are then asked their level of agreement with the responsiveness of government in addressing needs of society

(PERNS) and whether the government is run in the best interests for society as a whole or 
only for the benefit of a few (PEGFP). These variables measure the level to which the respondent feels the government works in the best interest of society or in the interest of the state and specific classes. Finally, respondents are asked to state the importance of their vote and participation in the electoral system (PEVPI). An additive scale using these variables produces the Political Efficacy Index (POLEF), which measures the overall political efficacy levels of the respondent.

Political Knowledge Index (PKIND)

According to Dahl (1971) for a democracy to flourish several thresholds must exist. Two of the primary criteria are minimum economic and literacy standards, which ensure the citizen is capable of political participation. Przeworski and Limongi (1997, p. 159) state that the greater a state's per capita income the greater chance democracies have of surviving. Once the ability to participate has been established, the citizens must generate knowledge sufficient to produce politically informed decisions. The level of political knowledge is measured by the respondents' ability to name the President of Nicaragua (PKPRN) and the mayor of the respondent‘s city or town (PKMCT) as a measure of domestic political knowledge, and the President of the United States (PKPUS) as a test of international political knowledge. Responses are coded "2" if the respondent knows the political figure and a "1" if they do not. The responses are added to create the Political Knowledge Index (PKIND), measuring the overall political knowledge of the respondent.

Interpersonal Trust (IPTRUST)

Interpersonal trust is the level of trust an individual has in other individuals on the basis of a reciprocal relationships. These relationships outline the patterns of civil 
interaction in a democracy. According to Putnam $(2000,1995,1993)$ as reciprocal civil interaction between individuals increase, so to does the level of trust between the two individuals. As the number of reciprocal civil interactions between individuals increases the level of trust in people increases. The more the individual trust people, the more they trust people in government, and the more general trust that develops the more the individual begins to trust government as an institution.

To explore the level of interpersonal trust in Nicaragua, respondents are asked a series of questions with the level of agreement ranging from "strongly agree (5)" to "strongly disagree (1)". The statements measure the respondents' beliefs in the trustworthiness of people in general (IPTGT); whether people try to help other people the majority of the time (IPTHO); and whether generally people do not try to take advantage of them (IPTNA). These three variables (IPTGT, IPTHO, IPTNA) are combined to create the Interpersonal Trust Index (IPTRUST), which provides an overall measure of the level of interpersonal trust found in the respondent.

\section{Confidence in Governmental Institutions (CIGIND)}

Two different variables have been created to gauge the respondent's attitudes towards Nicaraguan domestic political institutions and political figures. The first series of statements asks respondents to scale the level of confidence they have in various institutions on a five point scale from "total confidence (5)" to "none at all (1)". Political institutions examined include the public educational system (PEINC2), the legal or judicial system (PEINC4), police (PEINC8), political system in general (PEINC11), the National Assembly (PEINC9), and the president of Nicaragua (PEINC12). These variables create an additive scale of overall Confidence in Governmental Institutions 
Index (CIGIND). Non-governmental institutions included on the list include the Roman Catholic Church (PEINC1), the respondents’ church or denomination (PEINC2); the press (PEINC5); community organizations (PIENC7); Organizaciones representantes de los commerciantes or trade unions (PEINC6); and large corporations (PEINC10). Belief that Government Actions are Correct (BGAIND)

The second variable of trust in governmental institutions asks respondents to indicate their level of belief in the correctness of government actions. In making the link between individual attitudes and beliefs, associational activity outside the state, and trust for the government, a debate exists as how to approach it. Muller, Jekham, and Seligson (1994) argue that, if asked whether or not respondents trust the government they will answer according to specific trust or distrust of the candidates or political figures they are familiar with. Belief in the correctness of governmental actions differs from the level of confidence in political institutions because, rather than asking respondents to think solely of an institution, it adds a second component requiring respondents to think of an action taken by that specific institution. On a five point scale, from "almost always (5)” to “never (1)” respondents indicate their belief in the correctness of actions taken by: the government of Nicaragua (PETNG); the president (PETFG); National Assembly (PETRG); and the municipal government of the respondent's city or town (PETLG). These responses are combined to create an overall additive index known as the Belief in Correctness of Government Actions Index (BGAIND).

\section{Alternative Political Expression Index (APEIND)}

A third line of inquiry asks respondents to indicate the types of acceptable political participation and who can participate in the political process. To understand 
whether respondents support revolutionary action or what forms of political participation are acceptable in a democratic polity, they are asked to state their level of agreement with the right of a person to sign a petition (GCPPA), join a boycott (GCBPA), occupy factories and buildings (GCOBA), and attend lawful or legal demonstrations (GCLDA). The responses are coded from "strongly agree (5)" to "strongly disagree (1)" and combined in an additive index where the greater the combined score, the greater the tolerance for political participation outside the voting mechanism. The greater the toleration of alternative forms of expression, the better the democratic concepts of freedom of assembly and expression have been institutionalized.

\section{Openness of Political Participation Index (OPINDX)}

To explore the level of dissent tolerated, a series of statements invites respondents to indicate whether a person who has only negative things to say about the government should have the right: to vote (GCSVV); to attend legal demonstrations (GCSSD); to run for political office (GCSPO); and to appear on radio and television to make public speeches (GCSRS). The responses are used to understand if respondents believe in the rights of individuals with different political views to participate in the democratic process. The greater the level of tolerance, the better democracy has been institutionalized. Nicaragua provides an interesting case study for political science as these types of political participation are constitutionally protected and accepted without the fear of violent retribution for the first time in the lives of most adult Nicaraguans.

Finally, to gain an understanding of the spectrum of political ideology, respondents are asked to place their personal political beliefs on the left right continuum (GCLRC). The question asks the respondent to pick a number between " 1 " representing 
the left and strong FSLN affiliation, “5” representing centrality or no affiliation, and “10” representing the right or strong PLC affiliation.

\section{Religious Denomination Independent Variables}

\section{$\underline{\text { Religious Denomination }}$}

A number of independent and control variables have been created to ascertain the effect of specific religious institutions. The principal independent variable asks respondents to state their primary religious denomination (RBPRP). Respondents are also asked to state whether they are members of more than one denomination (RBMOD). Many people in the process of conversion may claim affiliation to more than one denomination. A third follow up asks respondents to state which denomination they practice most often (RBNOC). In these cases the denomination most practiced becomes coded as the respondent s’ primary religious denomination. Finally, respondents are asked if they have ever converted from one religious denomination to another (RBORP); how long since the conversion (RBNYA); and the reason for conversion (RBRFC). These questions measure the depth of the conversion as newer converts may not be as faithfully aligned with their newly adopted denomination and may return to their previous denomination. For example as Jacobs (1987, p. 305) points out that deconversion from charismatic forms of religion are not uncommon especially when adherents become disaffected or disappointed in their new religion or religious leaders.

Difficulties emerged in distinguishing between different denominations, especially within the three forms of Catholicism. Consequently, Charismatic and Progressive Catholics may be underrepresented in the sample. As a test of religious knowledge and toleration, respondents are asked to state their level of agreement with 
various religious denominations as read from a list (RBAOD). Denominations provided to respondents are: The Catholic Church (RBAOD1); Progressive Catholicism or CEBS (RBAOD2); Pentecostals (RBAOD3); Protestants (RBAOD4); Baptists (RBAOD5); Evangelicals (RBAOD6); Seventh Day Adventists (RBAOD7); Jehovah’s Witnesses (RBAOD8); Mormons (RBAOD9); Muslims (RBAOD10); Hindus (RBAOD11) and Buddhists (RBAOD12). In many cases respondents claimed membership in a Protestant denomination such as Baptists, but may have also stated that they disagreed with Protestants when read from the list. Therefore, many respondents may not be able to distinguish between denominations, thus complicating the clarification of a particular respondent s' denomination. Confusion may also be attributed to the independent nature of Nicaraguan Evangelical Churches, as well as their use of Catholic rituals and practices in the conduct of worship. ${ }^{8}$

Traditional Catholicism is defined as a form of Catholicism practiced within a formal Catholic Church, which meets regularly on Sunday where a parish priest performs the weekly services. Liberation Theology based Catholicism, also known as “Progressive” Catholicism, is defined in accordance with Williams' (1992) definition. Williams defines it as that sector of the institutional church dedicated to building a grass roots Church in Nicaragua. The grassroots model advocates the decentralization of church decision-making and authority, with CEBs serving as the fundamental organization units in the church. Charismatic Catholicism is defined as those Catholic Churches that engender Protestant characteristics such as devotion to the Bible, individual relationship with God, and focus on evangelism.

\footnotetext{
${ }^{8}$ The author was not fortunate enough to attend an Evangelical service as an invitation was never given. However, on several occasions the author was able to listen and see Evangelical worship from the street.
} 
Evangelical Protestantism is defined as a form of Christianity that is non-Catholic and is not Pentecostal. As Stoll (1993, p. 4) noted the term "Evangelical” in Latin American encompasses all non-Catholic Christian denominations. Due to their independent nature, the effect they have on society will crosscut their formal boundaries. Pentecostalism is a form of Evangelical Protestantism that is analyzed separately. Pentecostals may be different in that they emphasize the "Gifts of the Holy Spirit", doctrinal differences include the belief in sanctification. The belief in replicating Christ's life on earth may increase a belief in "other worldliness" as shown through belief in faith healing and the practice of speaking in tongues. As a result of this otherworldliness Pentecostals rely much less on social structures. This is done to determine if there is any difference between Evangelical Protestantism and Pentecostalism in terms of civil society output.

Nicaragua provides an interesting case as the Pentecostal movement has failed to grow as rapidly in Nicaragua as in other Latin American countries such as Guatemala and El Salvador. ${ }^{9}$ However, if the Pentecostal movement catches on, Evangelical Protestantism and Pentecostalism may become competitive for adherents and possibly create a fault line within Nicaragua's religious structure. Other religious denominations represented such as Jehovah’s Witnesses, Mormons, Seventh Day Adventists, Baptists, and Protestants are also coded (RBAOD). All non-Catholic Christian denominations are also pooled to construct a Catholic and Evangelical variable (RBPRP4), for exploration of differences between the two major Christian movements.

\section{Religiosity Independent Variables}

\footnotetext{
${ }^{9}$ Pentecostalism as percentage of population is $7.65 \%$ in Guatemala (World Christian Data Base) and 7.34\% in El Salvador (World Christian Database), 7.65\% in Nicaragua (World Christian Database), only $1.2 \%$ found in this study.
} 
Taking into account the difficulties of categorizing respondents by their denomination, religiosity scales have been constructed to offer a second avenue for discerning the effects of religion on civil society and democracy. Religiosity measures the role religion plays in the everyday life of the average citizen. One question often posed when studying religiosity is to ask the respondent to indicate how important God is in their life (RBIGL) on a 10-point scale. Unfortunately, in Nicaragua this question showed little variation as most respondents placed maximum importance of God in their lives.

\section{Level of Religious Participation (RBLRP)}

The most popular method for studying the level of religious participation is the frequency of church attendance outside of weddings, funerals, and christenings. ${ }^{10}$ While participation is clearly an important construct of religiosity, the frequency of attendance is only one dimension and very difficult to determine. Self-reported statistics by individual churches and denominations tend to be inflated and unreliable, especially given the supply side religious explanation where new churches and denominations establish their place in society through membership (Inglehart and Norris 2004; Iannicone, Fink and Starke 2000; Gill 1999). Face-to-face interviews also provide challenges because religious devoutness remains a noble characteristic, even among skeptics, giving respondents an incentive to exaggerate attendance. In the case of “Progressive Catholicism,” much of its worship and activities occur outside of a formal Cathedral and inside the house of one of its members or a community center. Generally, Evangelical Churches limit formal participation by only convening worship services on Sundays and Wednesdays. In Traditional Catholicism masses occur daily.

\footnotetext{
${ }^{10}$ See the World Values Survey /European Values Survey 1999-2001; Variable Name - V185
} 
For Evangelical adherents who have to leave their immediate neighborhoods to reach a place of worship, attendance may be limited by the ability to absorb extra time and transportation costs incurred in going to a service. The Catholic dioceses in Nicaragua long ago erected Cathedrals in cities and towns within walking distance to most neighborhoods. However, in the more mountainous and rural regions, traveling to Church services can be impractical. For many rural Nicaraguans, the only opportunities to engage in official religious practices are during infrequent trips made by priests to remote villages to hear confessions or rare visits to larger towns with markets. Though these individuals may not have the opportunity officially to practice their religion as do urban Nicaraguans, the use of religion in the daily life of rural Nicaraguans may be even greater.

This study chose to measure participation through the respondent's use of God for day-to-day guidance, another significant dimension of participation. If an individual consults God daily for answers and to make decisions, then each day the respondent is praying or participating in worship and practicing religion. This variable helps control for the disparity in participation that might occur as a result of religious affiliation. The respondent was asked how often they pray outside of religious services (RBPOR). The greater frequency with which respondents pray outside of religious services, the greater they participate in religion.

\section{Level of Religious Value (RBLRV)}

A second component of religiosity is the Level of Religious Value (RBLRV), which measures the depth of belief among respondents or how literally respondents take the Bible as the irrefutable Word of God. Questions investigating the personal depth of 
religion ask respondents if the Bible contains the word of God and is literally true (RBBLT); and whether eternal life is possible only for those who believe in Jesus Christ as God and Savior (RBHBG). These variables also measure the degree to which the respondent uses the Bible as a guide to every day life.

Level of Religious Belief (RBLRB)

The third component to religiosity is the Level of Religious Belief (RBLRB) and is designed to measure the breadth or knowledge of concepts used by the respondent when interpreting the world via Biblical references. The more concepts respondents believe in, the greater the level of religious belief and hence religiosity. Respondents are asked whether they believe in God (RBWTB1), Life after Death (RBWTB2), a Soul (RBWTB3), the Devil (RBWTB4), Resurrection of the Dead (RBWTB5), Hell

(RBWTB6), Heaven (RBWTB7), Sin (RBWTB8), and Reincarnation (RBWTB9). These variables are coded "yes (2)" if respondents believe in the concept and "no (1)" if they do not.

\section{Religiosity (RELIGIOSITY)}

In an effort to keep the number of variables to a minimum, the individual components of the Level of Religious Belief (RBLRB), the Level of Religious Value (RBLRV), and the Level of Religious Participation (RBLRP) have been combined to create an overall Religiosity (RELIGIOSITY) index variable. This variable provides a thorough measure of how deeply respondents hold religion, their knowledge of religion, and how often they participate. In the additive Religiosity index (RELIGIOSITY), the higher the score, the greater the respondent's religiosity. 
To examine the role of religion and its intersection with society and politics, a two-part line of questioning has been created for the constructions of index variables. These index variables measure the role respondents believe religious institutions should carry out in society as well as the effectiveness of religious institutions in implementation of these functions.

\section{$\underline{\text { Role of Religion in Society (RBCRS) }}$}

The first line of questioning surveys the role religious institutions should, and often do, perform in society and Church-State relations. Respondents are provided with series of issues from which they reply by stating whether it is appropriate for "the Church” to address (RBCRS). ${ }^{11}$ These variables measure the degree of involvement religious institutions should have when moral issues force the Church and Government into interact with one another. In short, it measures which set of institutions should be dominant when dealing with certain issues. A second question asks the respondent if the church he or she attends should work to solve the social problems of Nicaragua (RBSSP). This variable measures the respondent's attitude toward the role of "the Church" in civil society irrespective of the role of government.

\section{View of Religious Success in Society (RBCPAI)}

The second line of questioning measures how effective religious institutions are in shaping society and addressing specific issues. Respondents are asked whether religious organizations can be effective addressing problems of the community (RBRAP). Second,

\footnotetext{
${ }^{11}$ RCBRS issues provided to the respondent: Disarmament; Problems of the Third World; Extra Marital Affairs; Drug Addiction; Alcoholism; Unemployment, Racial Discrimination; Euthanasia; Homosexuality; Ecology and Environment; Politics and Government; and Human Rights. The respondent was also asked about abortion, but due to mistranslation and misunderstandings it was rarely understood and not asked throughout most of the survey. The question also does not specify which religious denomination the interview is discussing; the question simply states "the Church".
} 
respondents are asked whether the church is providing adequate answers to: the moral and social needs of the country (RBCPA1); problems of family life (RBCPA2); spiritual necessities of the population (RBCPA3), social problems facing the country (RBCPA4); financial problems of the poor (RBCPA5); and finally, if the church provides a sense of community (RBCPA6). Together these variables provide measure of how well "the Church” is generating and participating in civil society. These variables are combined to create an additive index variable summarizing the effectiveness of religious institutions in society called the Success of Religious Organizations in Society Index (RBCPAI). Higher scores indicate respondents believe the Church is effective in its contribution to civil society and lower scores mean respondents do not view the Church as providing valuable output in civil society.

\section{Control Variables}

Religion is not the only factor contributing to a vibrant civil society. Therefore, to accurately portray its effect a number of control variables have been collected. These variables are the age of respondents, the respondents' level of education, gender, and income level.

\section{Age (DIAGE1)}

To operationalize age, respondents are asked to provide the interviewer with the year they were born. Age is a sensitive issue everywhere in the world, and many respondents will misrepresent themselves if simply asked to state their age. The year provided by the respondent is subtracted from 2003, the year of the survey, and coded as the age of the respondent (DIAGE1). For descriptive purposes the ages are also aggregated and coded into scales from “18-28 years of age (5)”, “28-39 years of age (4)”, 
“40-50 years of age (3)”, 51-61 years of age (2)”; and “62 plus years of age (1)” to create an age ranking variable (AGERANK). The belief, at least in the United States, is that older respondents provide greater contributions to civil society (Putnam 2000, p. 247277). However, this may not be the case in Nicaragua as younger generations have experienced a more open civil society rather than the muted civil society experienced by the previous generations.

\section{Economic Level (DIINF)}

The income variable is constructed by asking respondents to estimate their personal monthly minimum income in Córdobas (DIINC), the currency of Nicaragua, as well as the minimum monthly income of the household (DIINCF). From February through July, 2003, the exchange rate for the Córdoba fluctuated between C $\$ 14.60$ : U.S.\$1 to C $\$ 15:$ U.S.\$1. For this research, income is calculated on a C $\$ 15:$ U.S.\$1 ratio. The greatest number of the two variables (DIINC and DIINCF), are coded into a third column to provide an overall income scale from "0 to 2000 Córdobas per month (1)”, “2001 to 4000 Córdobas per month (2)”, “4001 to 6000 Córdobas per month (3)”, “6001 to 8000 Córdobas per month" to "8001 or more Córdobas per month (5)”. It is theorized that (Przeworski and Limongi 1997; Dahl 1971) the greater the income, the greater the contribution to civil society because the respondent will have more leisure time and interest in politics and will provide greater contribution to civil society as more time is available for joining organizations and participating in associational activities. These forms of activities will make respondents better informed and more participatory in various political and associational activities. 
The income data is difficult to accurately collect as Nicaragua is one of the poorest nations in the western hemisphere. Nicaragua also has a large informal economy. Participants in this economy may not have an accurate calculation of their monthly income, as it may fluctuate greatly from month to month. Respondents may also choose to exaggerate or minimize their income due to surveyor interference. To control for interference, respondents are also asked: how many people live in their household (DINOP), their employment status (DIEMP2); occupation (DIJOB); whether they live in a house or apartment (DILAH); rent or own (DIOWN); whether they have a telephone (DITEL), television (DIHTV), refrigerator (DIREF), and radio (DINOR). The surveyor also observed the type of floor (DIFLR) and roof (DIROF) of respondents' dwellings. These variables are used to provide a second measure of income level that may be more accurate due to the reduction of surveyor interference.

\section{Gender (DIGEN)}

Gender is an important variable in studying political and civil activation in traditional societies. It is further intensified in studies of religion and politics; women have been the key impetus for the rise in both Progressive Catholicism and Evangelical denominations. To operationalize this variable, the interviewer observed the gender of the individual and coded men as " 0 " and women as " 1 ".

\section{Education Level (DIEDU)}

A final control variable, which is central to understanding the interaction between the respondent and civil society, is education. Theoretically, the greater the educational achievement of the respondent, the greater the possibility respondents participate in the political process and organizations providing associational activities. The more educated 
respondents, the greater interest and knowledge the respondents have and the better capable they are to seek out, collect, and analyze information central to making informed political decisions in their participatory venues such as voting or seeking solutions to society's ills. Asking respondents the last year or grade of school they completed produces the education variable (DIEDU). The responses were then aggregated into an education scale from: "No formal education (1); "primary education (2)"; "secondary education (3)"; "university (4)”; to “formal education beyond university (5).” Responses are coded so that if respondents attended university, but did not graduate; they are coded as “university (4)”. Once again, surveyor interference may cause respondents to exaggerate or minimize their educational experience so a second avenue to tap into educational levels was created.

These variables also explore the respondent's regularity of gathering information on political issues, mainly through the press. Respondents are asked: how often they watch the news on television (DINTV); how often they listen to news on the radio (DINOR); and the frequency at which they read the newspaper (DIFNP), all on a weekly basis.

\section{Regression Models}

Variables from the survey are combined in different ways to create multiple linear regression models measuring the effects of religion, age, income, and education on the different aspects of the three forms of civil society. Civil Society I represents a democratic civil society where participation in associational activities creates positive attitudes towards democracy and democratic institution. Civil Society II represents a form of civil society that is anti-regime, or as in the case of the dictator, creates a civil 
society where the associational activities are aimed at ousting repressive leaders. Finally, Civil Society III is a form of hate-filled civil society where associational activities are aimed at a form of hyper-nationalism pitting one group against another usually through violent forms of activities (Booth and Richard 2002).

Figure 3-1 provides the formula for the multiple regressions conducted in analysis of the survey data.

Figure 3-1: Formula for Multiple Regressions

$\underline{\mathrm{Y}=\mathrm{a}+\mathrm{b}_{1}} \underline{1}_{\underline{\mathrm{X}}} \underline{\mathrm{X}}_{\underline{1}}+\mathrm{b}_{2} \underline{\mathrm{X}}_{2} \underline{\mathrm{X}_{2}}+\ldots+\mathrm{b}_{\mathrm{p}} * \underline{\mathrm{X}}_{\mathrm{p}}$

Traditional Catholic Multiple Regression

FOCIND = CATDUM + DIGEN + DIAGE1 + DIEDU + DIINF

Progressive Catholic Multiple Regression

FOCIND = CEBDUM + DIGEN + DIAGE1 + DIEDU + DIINF

Evangelical Multiple Regression

FOCIND = EVANDUM + DIGEN + DIAGE1 + DIEDU + DIINF

Religiosity Multiple Regression

FOCIND = RELIGIOSITY + DIGEN + DIAGE1 + DIEDU + DIINF

Note: The above models are demonstrating the formula using the Formal Civil Society Index as the dependent variables. The formula is repeated for each of the eight civil society dependent variables

\section{Civil Society I Models}

If Civil Society I is being developed or encouraged by a specific denomination, then positive significant relationships should exist across all of the eight dependent variables measuring civil society and its effects. There should be significant positive relationships between religious denomination (CATDUM, CEBDUM, EVANDUM) and: Formal Civil Society Index (FOCIND); Informal Civil Society Index (ICSPIN); Political Efficacy Index (POLEF); Interpersonal Trust Index (IPTRUST); Political Knowledge 
Index (PKIND); Belief in Governmental Institutions Index (BGAIND); Confidence in Governmental Institutions Index (CIGIND); and Openness of Political Participation Index (OPIND).

\section{$\underline{\text { Civil Society II Models }}$}

If Civil Society II is being developed through religious associational activities then there should be positive significant relationships between religious denomination (CATDUM, CEBDUM, EVANDUM) and Informal Civil Society Index (ICSTIN), Interpersonal Trust Index (IPTRUST), Political Knowledge Index (PKIND), and Openness of Political Participation Index (OPIND). As Civil Society II is known as an “anti-regime” form of civil society, then there should be significant negative relationships between religious denomination (CATDUM, CEBDUM, EVANDUM) and: Formal Civil Society Index (FOCIND), Belief in Governmental Institutions Index (BGAIND), and Confidence in Governmental Institutions Index (CIGIND).

\section{$\underline{\text { Civil Society III Models }}$}

If Civil Society III is being developed through religious associational activities there should be significant negative relationships between religious denomination (CATDUM, CEBDUM, EVANDUM) and Formal Civil Society Index (FOCIND), Informal Civil Society Index (ICSPIN), Political Efficacy Index (POLEF), Interpersonal Trust Index (IPTRUST), Political Knowledge Index (PKIND), Belief in Governmental Institutions Index (BGAIND), Confidence in Governmental Institutions Index (CIGIND), and Openness of Political Participation Index (OPIND). 


\section{Chapter Four}

\section{Introduction}

Chapter Four explores the state of civil society in the populous Pacific region of Nicaragua during spring and summer of 2003. It also investigates the eight civil society index variables in Nicaragua. The first section considers the state of formal civil society in Nicaragua by surveying membership levels in formal organizations such as sports teams, art and educational organizations, labor unions, professional associations, environmental organizations, and philanthropic organizations. The second section examines the variables that compose the informal civil society dependent variables. This is an investigation of the degree to which people participate in neighborhood groups and the respondent's propensity to attend, organize, and participate in meetings for solving problems of the community and its members. Informal civil society also looks at the other forms of supportive activities such as donating money and materials to resolve the problems of the community and its members.

The third section deals with the effects of participation in civil society such as attitudes towards various political institutions and leaders, the amount of confidence the respondents have in political institutions, and the belief that the actions of the government are correct. This section also explores the level of support for gradual changes by examining the types of political activities the respondents feel are acceptable.

\section{The State of Formal Civil Society in Nicaragua}

Civil society in Nicaragua is a study in contrasts. While vibrancy in civil society does exist, mainly through the contributions of the informal sector, the state of formal civil society structures and participation outside of religious institutions are not 
encouraging for the maintenance of democratic political institutions. Table 4-1 is a summary of the index variable for the level of participation in formal organizations, such as labor unions, sports teams, educational and arts organizations, and political parties provided by the respondent.

Table 4-1: Summary Table For the Formal Civil Society Index (FOCIND2)

\begin{tabular}{l|cc}
\hline & Frequency & Percentages \\
\hline High Formal Civil Society Participation & 7 & 1.2 \\
Medium-High Formal Civil Society Participation & 16 & 2.7 \\
Medium Formal Civil Society Participation & 36 & 6 \\
Medium Low Formal Civil Society Participation & 121 & 20.1 \\
Low Formal Civil Society Participation & 421 & 70.0 \\
Total (N) & 602 & \\
\hline
\end{tabular}

As demonstrated by Table 4-1, 90.1 percent of the respondents exhibited "low" or “medium-low” formal civil society participation. An overwhelming majority of the population is either not a member of an official organization or a non-active member. According to Almond and Verba (1963) democratic political cultures have a high numbers of “participants”, complimented with high numbers of “subjects” and “prochials”. In Nicaragua then the high numbers of "participants” are missing.

Lack of formal participation is in part the product of a civil society deficit due to the decades of a closed civil society under both the Somoza and Sandinista regimes. To the Somoza dictatorship, especially in its later years, organizing outside the state was viewed as a threat to the regime and usually suppressed via force, particularly if the organization dealt with political issues. Conversely, under the FSLN, community or neighborhood organizing was a central tenet to their communist ideology. However, state imposed organization automatically takes associational activity out of the realm of 
civil society. Civil society requires voluntary participation outside the state in order to articulate and amass demands made on the state (Brysk 2000; Fukyama 1995; Gellner 1994; Linz and Stepan 1993). Today, many view the actions of the Sandinista regime as being as repressive as those of the Somoza regime. Respondents occasionally expressed that community organizing was an effort to strengthen the FSLN in response to the Contra activities rather than enhancing the community. Sports, Arts, and Educational Organizations (FOCSR)

The most popular type of formal civil society participation occurs in sports organizations and arts, education, and folkloric groups. "Active" and "very active" members of sports organizations make up 9.9 percent of the total sample population and 8.3 percent claim to be members of educational or artistic organization. The most popular sport in Nicaragua is baseball, followed by boxing, basketball and soccer. Sport role models like Dennis Martinez, and Roberto Clemente (though not Nicaraguan died delivering relief supplies in the wake of the 1972 Nicaraguan earthquake) have made baseball the national passion. Nicaragua has its own professional league, where games are often crowded and the season is long ${ }^{12}$.

Nicaraguans also exhibit a strong affinity for their culture. Folk dancing and historical interpretations are a major part of Nicaraguan life. Cities like Granada and Masaya have weekly events, known as "La Serenata". These events usually begin with a number of dances staged by the various regional, youth folkloric groups followed by a mix of musicians performing a mix of popular and traditional music. Events like "La

\footnotetext{
${ }^{12}$ The author attended the 2003 National Championship Game (Granada vs. Leon), which was announced only days before the game and sold out in minutes. The stadium was packed well beyond capacity and thousands stood outside in the parking lot to hear the game.
} 
Serenata” not only provide a weekly lesson in Nicaraguan culture and history, but also offer an enormously popular social activity for the entire city. ${ }^{13}$ Political Parties (FOCPP)

The second component of the Formal Civil Society Index (FOCIND) variable asks respondents whether they are members of political parties. Table 4-2 shows that only 12.5 percent of the respondents claim to be members of political parties, with 87.5 percent of the total respondents stating no party membership.

Table 4-2: Member of a Political Party (FOCPP)

\begin{tabular}{l|cc}
\hline & Frequency & Percentages \\
\hline Very Active Member & 6 & 1 \\
Active Member & 47 & 7.8 \\
Somewhat Active Member & 9 & 1.5 \\
Inactive Member & 13 & 2.2 \\
Not a Member & 527 & 87.5 \\
Total (n) & 602 & \\
\hline
\end{tabular}

Furthermore, only 10.3 percent of the respondents consider themselves to be "active" members in their respective parties. Today, Nicaragua is technically a multi-party system, but only three parties are active as a result of strict election laws passed in 1996 (U. S. Department of State, www.state.gov/r/pa/ei/bgn/1850.htm). Parties participating in the 2001 elections were the Sandinista National Liberation Front (FSLN), Liberal Constitutional Party (PLC), and the Conservative Party of Nicaragua (PCN). Despite low party membership, elections in Nicaragua stimulate high voter participation. This research found 86.2 percent of the respondents voted in the November 4, 2001 presidential elections while others sources have reported participation rates over 90 percent (Schneider 2002; Mihaly 2002). Suffrage is universal and granted at the age of

\footnotetext{
13 These "La Serenades" draw thousands of people from the community as well as tourists, who have begun flocking to Nicaragua for its natural and cultural beauty as well as for its low prices.
} 
16. The last elections were held November 4, 2001, requiring that respondents to the survey to have been 18 in 2003.

Politically, Nicaragua is a divided country. Though most Nicaraguans claim no party membership, they do express affiliation in terms of left and right as illustrated in Table 4-3.

Table 4- 3: Left - Right Political Continuum (GCLRC)

\begin{tabular}{l|cc}
\hline & Frequency & Percentage \\
\hline 10 - Extremely Right & 87 & 14.5 \\
9 & 39 & 3.6 \\
8 & 61 & 10.1 \\
7 & 41 & 6.8 \\
6 & 17 & 2.8 \\
5 - Center & 225 & 37.4 \\
4 & 11 & 1.8 \\
3 & 33 & 5.5 \\
2 & 18 & 3.5 \\
1 - Extremely Left & 69 & 11.5 \\
Total (n) & 601 & \\
\hline
\end{tabular}

Respondents claiming to be in the center or expressing no political affiliation made up 37.4 percent of the total sample population, 22.3 percent are supportive of the left and the FSLN, and 37.8 percent sympathetic to the right and the PLC and PCN parties. Party affiliation is evident in the make up of the executive and legislative branches of government. The PLC currently controls the executive, with Enrique Bolanos receiving 52 percent pf the vote compared to the FSLN's Daniel Ortega's 42 percent in 2001. In the legislature, “the Liberal Alliance”, a PLC umbrella group consisting of the PLC, Nicaraguan Party of the Christian Path (PALI), Independent Liberal Party for National Unity (PLUIN), and Central American Unionist Party (PUCA), garnered 46.3 percent of 
the seats in the unicameral National Assembly compared to the FSLN's 36.55 percent, the National Party for the Christian Road (PCCN)'s 3.73 percent, and the Conservative Party of Nicaragua 's (PCN) 2.12 percent in 2001(CIA World Fact Book, 2004)

\section{Labor Unions (FOCLU)}

Labor Unions are an example of formal civil society organizations that were muted during the FSLN regime, but are slowly beginning to reassert themselves in society. The Sandinistas came to office claiming that they would enact legislation that “...guarentee(s) and promote(s) labor, trade and people’s unions, both in the city and in the countryside” (Belli 1986, p. 79). Prior to the revolution in 1979, the leading labor union was the Nicaraguan Confederation of Labor (CTN), with sixty-five thousand members. Other pre-revolutionary unions included the Independent Confederation of Labor (CGR-I), Syndicalist Action and Unity Central (CAUS), and the Council of Trade Union Unification (CUS), all of which were affiliated with leftist organizations such as the Nicaraguan Socialist Party, AFL-CIO, and Maoists (Belli 1986, p. 79-80).

Once in power, FSLN leaders established the Sandinista Confederation of Labor (CST) for urban workers and the Association of Agricultural Workers (ATC) for agrarian workers under the slogan “Only one workers’ class, only one trade union” (Belli 1986, p. 79-81). Resistance to join the CST and ATC led to harassment of private and independent unions by the FSLN. Acts of harassment carried out by the FSLN consisted of the storming of union halls, the jailing of independent union leaders and workers, and even mob violence by Sandinista loyalists (Belli 1986, p. 79-83).

The creation of Sandinista labor and trade unions and the suppression of independent and private organizations created a deficit in this type of civil society 
participation from which Nicaragua has been slow to recover. Today, only 5.5 percent of the total respondents say they are members of a labor or trade union. Of these respondents, 0.8 percent claim to be "inactive members", another 0.8 percent are “somewhat active members", and 3.7 percent are "active members" of labor unions. Overall, 569, or 94.7 percent of the respondents, stated no affiliation with trade or labor unions, which is not surprising given the suppression of independent labor unions.

Low membership among labor unions may also be attributed to the fact that 50 percent of Nicaraguans live under the poverty line (CIA World Fact Book, 2004).

According to the CIA World Fact Book 2004, Nicaragua has an unemployment rate of 24 percent; this research finds that 37.7 percent of the respondents are either unemployed or consider themselves to be out of the workforce (students or ama de casa). Of the 62.6 percent of people who claim to be employed, a large number of them are underemployed. College graduates can be found selling Cokes or other small products out of their homes due to a lack of opportunity to pursue the careers for which they are trained. ${ }^{14}$

Today the most popular type of trade and labor unions are those for transportistas. Transportistas are truck, taxi, and bus drivers who are organized into collectives to ease the burden of owning and maintaining vehicles that deteriorate quickly on Nicaragua's poor transportation infrastructure. The government does not provide public transportation in a country where automobile ownership is a relatively new phenomenon and out of reach for the majority of Nicaraguans. They rely on transportistas to provide them transportation for every day activities.

\footnotetext{
${ }^{14}$ At a number of interview with younger respondents the author was asked to take resumes and curriculum vitas back to the Unites States for circulation. These respondents all had finished study at the university level or beyond but have been unable to find work in the fields for which they were trained.
} 
A second type of popular trade or labor union is artisan cooperativas or collectives, where the majority of Nicaragua's tourist goods, such as pottery and paintings, are produced. The Pueblos Blancos area is home to a large population of artisans. Creating these products is very taxing on the artisan. To ease their burden, they often organize for the purposes of sales and marketing. In both transportation and arts cooperatives, respondents did not differentiate between these as trade unions or professional associations.

Outside of small transportation and arts collectives, very little has changed in the structure of labor unions since the time of the revolution. Today, the FSLN controls the National Workers Front (FNT), which is an umbrella group of eight labor unions: Farm Workers Association (ATC); Health Workers Federation (FETASALUD); Heroes and Martyrs Confederation of Professional Associations (CONAPRO); National Association of Educators in Nicaragua (ANDEN); National Union of Employees (UNE); National Union of Farmers and Ranchers (UNAG); Sandinista Workers Central (CST); and the Union of Journalists of Nicaragua (UPN). A second umbrella union organization, independent of the FSLN, is the Permanent Congress of Workers (CPT) that includes the Autonomous Nicaraguan Workers Central (CTN-A); Confederation of Labor Unification (CUS); Independent General Confederation of Labor (CGTR-I); and Labor Action and Unity Central (CAUS). Independent of these umbrella labor union groups are the Nicaraguan Workers’ Central (CTN) and Superior Council of Private Enterprise (COSEP) (CIA World Factbook, 2004).

\section{$\underline{\text { Professional Associations (FOCPA) }}$}


Closely related to trade and labor unions are professional associations, which also have been slow to recover from generations of a closed civil society. Today only 8.2 percent of the population claim to be "active” or "somewhat active” members of Professional Associations, with 0.3 claiming to be “inactive” members and 91.8 percent of the total respondents declaring “no” membership or affiliation with professional associations.

The concept of professional associations proved confusing to respondents as differences between unions and professional associations may not have been fully understood nor articulated. Today there are a large number of small professional associations representing lawyers, doctors, nurses, veterinarians, téchnicos, and engineers. Of the 45 respondents who are "somewhat active" or "very active" members of professional associations 17, are from the upper economic class or have family incomes of more than 8,000 Córdobas per month, 10 have family incomes between 4,000 and 8,000 Córdobas per month, and 18 respondents with less than 4,000 Córdobas per month. Thus, income plays only a limited role in determining membership in professional associations.

\section{Environmental Groups (FOCEO)}

Environmentally, Nicaragua is a mixture of natural beauty coupled with environmental tragedy. In Nicaragua everything, including drinks, are sold in plastic bags that litter the roads and streams in every populated area. Water pollution and the dumping of mercury by companies such as Kodak and Electroquímica Pesada (Elpesa) have virtually killed Lake Managua (Cuadra 1992; Kaliner and Faber 1988). In an effort to combat environmental problems, a number of small environmental organizations, 
mainly affiliated with the government, have been established. The most admired environmental organization is the Ministerio Del Ambiente y Recursos Naturales (MARENA), which "develops and fosters inter-institutional cooperation for the sharing, validation and adoption of methods to protect of water resources; assesses actions to protect, control and appropriate use of water resources in various areas” (www.iwrn.net). As a governmental organization MARENA is questionable as a provider of civil society and membership is not official. Respondents claiming "active” participation in MARENA generally based the concept of membership on whether they participated in projects and educational forums sponsored by the organization or worked there.

Ministerio Agropecuario y Forestal (MAGFOR) is another environmental organization popular among Nicaraguans. MAGFOR's goal is to promote sustainable agricultural development as a central tenet to the resurgence and reactivation of the Nicaraguan economy (www.magfor.gob, 2003). As a governmental organization, MAGFOR uses its resources to prioritize and develop those agricultural products, such as coffee, that make up the basis of the Nicaraguan economy. Where MARENA focuses on natural resources, biodiversity, and environmental quality, MAGFOR focuses on agriculture and forestry. As a governmental organization, MAGFOR's contribution to civil society is also limited and membership is not official but based on organizational interaction with respondents.

Visión Mundial, also known as World Vision International, is “...an international Christian relief and development organization working to promote the well being of all people - especially children"(www.wvi.org 2004). Though not purely an environmental organization, Visión Mundial does try to improve the immediate environmental and 
sanitation problems of those assisted by the organization. Once again, membership is not official but based on interaction with the Visión Mundial's projects and educational seminars. Visión Mundial is an international civil society organization with religious affiliation dedicated to improving the situation of the world's youth.

Overall, 4.8 percent of the total respondents are at least "somewhat active" members of an environmental organization, with 95.2 percent expressing "none” or “inactive” membership. The driving force for membership is age, with most members being students as 20 of the 29, or 68 percent, of members of environmental organizations are younger than 39 years of age.

Philanthropic or Charitable Organizations (FOCCP)

Membership in philanthropic and charitable organizations is a rarity in Nicaragua. To be a member of one of these organizations, a person must have the resources to be charitable, which is rare in one of the poorest states in the Western Hemisphere. Overall, 3.2 percent of the respondents stated membership in philanthropic and charitable organizations. Surprisingly, 66.7 percent of the respondents claiming membership in a philanthropic or charitable organization have family incomes of less than 6,000 Córdobas per month, or less than $\$ 400$ per month. ${ }^{15}$ This may not be indicative of membership in a charitable or philanthropic organization, but most likely affiliation based on receiving services.

\section{The State of Informal Civil Society in Nicaragua}

The majority of Nicaraguans' civil society participation occurs in the informal sector. Informal civil society is participation in the resolution of community problems or problems of one of its individuals through collective actions and/or the donation of

\footnotetext{
${ }^{15}$ Exchange rates are based on a 15 Córdobas $=\$ 1.00$, which was the bank rate in June 2003.
} 
money and materials outside membership in formal organizations. Individuals may participate in informal civil society by organizing and attending community meetings and donating work or money.

\section{$\underline{\text { Participation in Informal Civil Society (ICSPIN) }}$}

When asked whether the respondent belongs to a community group or organizations in his or her neighborhood, 15.8 percent of the respondents claimed affiliation, with 84.2 percent claiming no affiliation (IOCCG). In terms of donating work to solve the problems of the problems of the community or one of its members, a majority of the sample population, 53.2 percent, has donated some form of work (IOCDW). When asked what type of work they did, answers ranged from assisting the sick in getting medical care, raising money for funerals, working with street kids, working on infrastructure problems, and broad community issues. The respondents overwhelmingly stated that cleaning the neighborhood and street was the most popular activity. Respondents were also asked whether they had attended a meeting to solve community problems or the problems of individuals in the community (IOCAM); 43.2 percent stated they had attended a meeting. Finally, 25.4 percent of the respondents have organized a meeting to help solve community problems or those of one of its members (IOCNG).

These variables were combined to create the Informal Civil Society Participation Index (ICSPIN) as shown in Table 4-4. 
Table 4-4: Summary Table for Informal Civil Society Participation Index (ICSPIN)

\begin{tabular}{l|cc}
\hline & Frequency & Percentages \\
\hline High Participation & 40 & 6.7 \\
Strong Participation & 71 & 11.8 \\
Medium Participation & 116 & 19.3 \\
Low Participation & 146 & 24.3 \\
Does Not Participate & 227 & 37.8 \\
Total (N) & 600 & \\
\hline
\end{tabular}

As demonstrated from the Table 4-4, 37.8 percent of the respondents do not participate in informal civil society. This indicates that the respondents claimed not to have participated in any of the four types of associational activities. On the other end of the spectrum, 18.5 percent of the respondents claimed to have participated in at least three of the four community activities presented to them. It is a positive sign that in such an impoverished state a large number of its citizens have worked toward societal and community improvement in ways that are constructive for the maintenance of democratic institutions and development of civil society.

\section{$\underline{\text { Support for Informal Civil Society (ICSSIN) }}$}

Support for civil society means that irrespective of their active participation, respondents may also provide encouragement for civil society. Respondents show support by trying to resolve community and individual problems (IOCCP) and donating money and materials (IOCDM). Trying to resolve community and individual problems (IOCCP) differs from than donating one's personal work (IOCDW) in that the individual may not provide actual labor but has thought about or discussed with others resolutions to community and individual issues. 
Of the respondents, 40.7 percent have attempted to resolve the problems of the community or one of its members (IOCCP). With such a high percentage of the population involving themselves in the community and the lives of its members, activity and socializing is taking place. Nicaraguan society is intimate, with tight social connections renowned for gossip, making large cities of 80,000 seem like small towns. Giving is another popular associational activity as an overwhelming 65.3 percent have donated money and/or materials to solve community and individual problems. Donations include giving a few Córdobas, contribute construction materials for housing projects, providing clothing, and even giving scraps of left over food to street kids begging door to door and in restaurants.

One of the most fascinating observations is the willingness of Nicaraguans with very little to give to those with even less. For example, Granada has a large population of street kids who depend solely on scraps of food given to them by people eating in restaurants. While many of these street kids die from the effects of sniffing glue, murder, or accidents at young ages, very few, at least in Granada, appear malnourished. ${ }^{16}$ Managua is a different story, with a large number of street children living together in parks and vacant lots. ${ }^{17}$ Managua’s street kids appear in much worse shape, some showing symptoms of malnourishment, given increased competition among them and fewer interactions with sympathetic tourists in addition to the separation between the wealthy and poor found in the large and erratically constructed city.

\footnotetext{
${ }^{16}$ During the author's stay in Nicaragua, living with Donna Tabor, who works daily with street kids, two of them were murdered either by adults or other street kids, a few were seriously injured in traffic accidents, and a couple also simply disappeared, possibly traveling to other cities.

${ }^{17}$ One respondent showed the surveyor a park on the outskirts of El Jardín in Managua, where 30 to 40 street kids were lying like around fallen soldiers holding baby jars of shoe glue. Some appeared malnourished and were being attended to by international volunteers for wounds such as cuts on their feet.
} 
The two civil society support variables are combined to create the Informal Civil Society Support Index (ICSSIN2) as shown on Table 4-5.

Table 4-5: Summary Table for Informal Civil Society Support Index (ICSSIN)

\begin{tabular}{l|cc}
\hline & Frequency & Percentages \\
\hline High Levels of Support & 192 & 31.9 \\
Medium Levels of Support & 254 & 42.2 \\
Low Levels of Support & 156 & 25.9 \\
Total (N) & 604 & \\
\hline
\end{tabular}

This table shows that 74.1 of the sample respondents exhibit "medium” to "high" informal civil society support. These respondents demonstrated concern and made at least some attempt to improve society through peaceful means. It also shows that 74.1 percent of the respondents at one time or another have had hope or the belief that a small action could improve society and interacted enough with other individuals to know that problems exist. The hope or patience for peaceful resolution appears positive for the maintenance of Nicaragua’s domestic political structures.

$\underline{\text { Informal Civil Society Index (ICSTIN) }}$

To get an overall view of the state of informal civil society in Nicaragua the variables in the Informal Civil Society Support Index (ICSSIN) and those in the Informal Civil Society Participation Index (ICSPIN) are combined to produce the Informal Civil Society Index (ICSTIN) as shown on Table 4-6. 


\section{Table 4-6: Summary Table for Informal Civil Society Participation and Support Index (ICSTIN)}

\begin{tabular}{l|cc}
\hline & Frequency & Percentages \\
\hline Low Levels of Support and Participation & 204 & 34.2 \\
Medium Levels of Support and Participation & 306 & 51.2 \\
High Levels of Support and Participation & 87 & 14.6 \\
Total (N) & 597 & \\
\hline
\end{tabular}

When compared to the Formal Civil Society Index (FOCIND), this table shows that civil society participation and support is strong in Nicaragua, however it is unorganized.

Overwhelmingly, the types of civil society and associational activities taking place are informal or locally oriented. Community or neighborhood improvements are the most common form of associational activities taking place. Activities usually focused on infrastructure needs such as street repairs, housing issues, and cleaning the neighborhood. Essentially, communities at the barrio level take up activities that would normally be left to the state in economically developed countries. Neighborhood groups tended to be structured around a neighborhood "jefe" or president and a committee rather than within religious or other types organizations. These structures do appear to be a positive residual of the earlier FSLN form of organizing. These micro organizations deal not only with infrastructure issues, but also help raise funds from the neighborhood for things like funeral costs, medical costs, and hospital transportation. Neighborhood organizations are successful for the most part, as 74.1 percent of the respondents acknowledged having made some type or contribution. 


\section{Effects of Civil Society Support and Participation}

What are the effects of these interactions? How do these interactions affect attitudes towards the democratic system? Are people being socialized into accepting a democratic regime as a form of government?

Political Efficacy (POLEF)

Political efficacy measures the level to which the respondent feels his or her participation in the political process affects the conduct of government. In a measure of the level to which the respondent feels they have access to public officials, 40.2 percent of the respondents either "agree" or "strongly agree” that they feel comfortable asking for the help or cooperation of a member of the national assembly (PEHNC). An even larger 55.9 percent of the respondents feel comfortable asking the mayor of their city or town or his/her representative for help or cooperation (PEMMO). It is encouraging for the maintenance of democratic institutions as a majority of the population feel they have access to some venue of government to make demands and raise grievances on the state.

As an overall measure of whether this access affects the conduct of government, 63.3 percent either "strongly disagreed" or "disagreed" that the government was responding to the needs of society (PERNS). It is discouraging that an overwhelming majority feels that even though they make demands on government the state does not respond. However, the question of responding is not a simple answer, especially given the level of poverty. Do Nicaraguans believe that the government, is simply not responding to society or is government responding the best it can with the resources available to it? 
To answer this question, the respondent was asked whether the country is run for the benefit of a few or in the interest of society as a whole (PEGFP). Of the respondents, 68.6 percent feel the government is run in the interests of a few individuals. A minority, 31.2 percent of the respondents, considers government to be run in the best interest of society. From these figures it is evident that respondents feel the government is choosing not to answer the needs of citizens, rather than not being incapable due to lack of resources. Distrust in the motives of government is not unexpected, given Nicaragua's history with autocracy under the Somozas and the oligarchy of the Sandinistas. The history of state structures in the surrounding states of Honduras, El Salvador, and Guatemala also illustrate the democratic deficit in the region, as domestic political institutions have rarely been mechanisms run in the interests of society as a whole.

Finally, the respondent is asked if his or her vote and participation in the electoral system is important (PEVPI). This measures the respondents overall feeling of affect in deciding on their representatives. A majority of 88.2 percent of the respondents feel their vote and participation in the electoral system is important. The respondents trust the election mechanism even though the majority of the respondents do not consider that the government is being run in the best interest of society.

The divergence among respondents between effectiveness choosing representatives with the belief those representatives do not govern in the best interest of society points to the concept of "personalism" or "Presidencialismo" common in Latin America. Ai Camp's (1999, p. 11-13) examination of the Mexican system found that the "viceroy” system, which governing structure in most of Latin America during colonialism, led to a belief in personalism or "Presidencialismo". Personalism consists 
of beliefs that state institutions mean little and all government outputs, good or bad, result directly from the executive. Overall, 68.6 percent of the respondents do not believe people in government are trustworthy, but 88.2 percent of the respondents feel their vote and participation in the electoral system is important, indicating a trust in governmental institutions. In short, Nicaraguans may trust democratic institutions even if they do not trust the individuals running those institutions.

An additive index of these variables, as demonstrated in Table 4-7, provides a general measure of political efficacy (POLEF).

\section{Table 4-7: Summary Table for Political Efficacy Index (POLEF)}

\begin{tabular}{l|cc}
\hline & Frequency & Percentage \\
\hline High Political Efficacy & 33 & 5.9 \\
Medium High Political Efficacy & 197 & 32.7 \\
Medium Political Efficacy & 179 & 32.2 \\
Medium Low Political Efficacy & 128 & 23 \\
Low Political Efficacy & 19 & 3.4 \\
Total (N) & 556 & \\
\hline
\end{tabular}

A 70.8 percent majority of the respondents have at least a "medium" sense of political efficacy, or believe their democratic expressions have an effect on the conduct of government. This is encouraging for democracy, as the majority believes their participation has an impact, irrespective of their beliefs about the intent or ability of politicians.

\section{Political Knowledge Index (PKIND)}

With a large percentage of the respondents feeling that their participation in the electoral system is important, the next issue is whether these respondents are making informed decisions. To measure the level of knowledge about politics, respondents were 
asked whether they could name the President of Nicaragua (PKPRN) and the mayor of their city or town (PKMCT), as a measure of domestic political knowledge, and the president of the United States as a measure of foreign political knowledge (PKPUS). Political knowledge is high in Nicaragua, with 96.8 of the respondents identifying the President of Nicaragua, 92.2 percent identifying their mayor, and 78.7 percent identifying the President of the United States. Political knowledge in general, as shown in Table 4-8, illustrates the political sophistication of the respondents.

Table 4-8: Summary Table for Political Knowledge Index (PKIND)

\begin{tabular}{l|cc}
\hline & Frequency & Percentages \\
\hline High Political Knowledge & 434 & 72.3 \\
Medium Political Knowledge & 142 & 23.7 \\
Low Political Knowledge & 23 & 4 \\
Total (N) & 600 & \\
\hline
\end{tabular}

An amazing 72.3 percent of the population could name all three of the political figures and 23.7 percent could name two of the three. Overall, 96 percent of the respondents exhibited "high” or "medium” levels of political knowledge. Nicaraguans do engender a sophisticated political knowledge and actively seek information regarding politics, as 78.5 percent of the respondents claim to watch the news on TV daily and another 14.5 percent watch it two or three times a week. At least two times a week, 93 percent of the population receives news about politics and events from which to create attitudes and beliefs about government and the way the world should work. Interpersonal Trust (IPTRUST)

The next relationship of inquiry is to measure the effects of civil society interactions and political knowledge on the level of trust respondent have in other individuals. Of the respondents, only 27.4 percent “agree” that people are generally 
trustworthy (IPTGT) and 39.3 percent “agree” that most of the time people try to help others (IPTHO). Twenty-nine percent feel that most of the time people do not try to take advantage of them (IPTNA). An astounding 78.3 percent of the respondents feel that if given a chance most people will try to take advantage of them (IPTTA). Earning a living in Nicaragua is a difficult task, especially given that 40 percent of all Nicaraguans living under the poverty line, with high underemployment and unemployment (CIA World Factbook 2004). Chances to earn Córdobas are limited, and many Nicaraguans will make the most of any opportunity. As evidence of this phenomenon, 83.4 percent of the respondents agreed or strongly agreed that most of the time people only worry about themselves (IPTWP).

To create a general measure of interpersonal trust, three variables (IPTGT; IPTHO, IPTNA) assessing the level of trust in other individuals were added together creating the Interpersonal Trust Index (IPTRUST4), shown on Table 4-9.

Table 4-9: Summary Table for Interpersonal Trust Index (IPTRUST)

\begin{tabular}{l|cc}
\hline & Frequency & Percentages \\
\hline High Interpersonal Trust & 10 & 1.8 \\
Medium High Interpersonal Trust & 71 & 12.5 \\
Medium Interpersonal Trust & 313 & 55.2 \\
Medium Low Interpersonal Trust & 145 & 25.6 \\
Low Interpersonal Trust & 28 & 4.9 \\
Total (N) & 567 & \\
\hline
\end{tabular}

Similar to the attitudes toward politicians, Nicaraguans do not hold high levels of trust in other individuals. A vast majority of 85.7 percent of the respondents exhibited "medium" to "low" levels of interpersonal trust. This phenomenon appears to be a result of economic hardships and desperation experienced by many Nicaraguans on a daily basis. 
To a North American in Nicaragua, prices at the beginning of the field research were much higher than at the end, as bargaining is expected for even the smallest of items in the cities, markets. In this sense, each purchase begins with an inflated price so that the seller can get the highest price the buyer is willing to pay. Each transaction involves the seller trying to take advantage of the buyer. The more often these interactions occur, the more socialized they become; thus the seller trying to take advantage of the buyer and vice versa is a fact of everyday life. Over time these transactions become a codified part of everyday life and may be one cause, or consequence, for the general lack of trust between individuals.

\section{Attitudes Toward Governmental Institutions}

How does this lack of trust for individuals translate into trust for governmental institutions? To gauge the level of trust for governmental institutions, the respondents were asked both about the confidence they have in these institutions (PIENC1-10) and whether they believe the actions of governmental institutions are correct (PET--).

\section{Belief That the Actions of Government Are Correct (BGAIND)}

Beliefs that the actions of the Nicaraguan government are correct, in both the individual variables and the index, show that the majority of the respondents express a medium to low belief. Of the respondents, 84.9 percent feel, at best, the actions of the National Assembly (PETRG) are correct "some of the time," with 52.7 percent stating the National Assembly is correct "almost never" or "never". Results for the President of Nicaragua, Enrique Bolaños, are slightly better with 78 percent stating his actions are correct at least "some of the time" and only 39 percent expressing "almost never" or “never” (PETFG). City, Municipal, or local governments receive the best ratings, but 
only slightly, with 75.5 percent of the respondents stating their actions are correct at least “some of the time” and 37.1 percent stating "almost never” or "never”(PETNG). When asked about the actions of the Nicaraguan Government as a whole, 86.4 percent of the respondents claimed its actions were only correct "some of the time," with 37.4 percent stating “almost never” or “never” (PETLG).

These four variables are combined to create the Belief That the Actions of Government are Correct Index (BGAIND) as illustrated in Table 4-10.

Table 4-10: Summary Table for Belief That Government Actions Are Correct Index (BGAIND)

\begin{tabular}{l|cc}
\hline & Frequency & Percentages \\
\hline High Belief Government Actions Are Correct. & 15 & 2.9 \\
Medium High Belief Government Actions Are Correct & 58 & 11 \\
Medium Belief Government Actions are Correct & 235 & 44.7 \\
Medium Low Belief Government Actions are Correct & 141 & 26.8 \\
Low Belief Government Actions Are Correct & 77 & 14.6 \\
Total & 526 & \\
\hline
\end{tabular}

As noted from the table, Nicaraguan's belief in the correctness of governmental institutions is relatively low. A meager 13.9 percent of the respondents demonstrate a “medium-high" or "high” belief that the actions of their government are correct. Nicaraguan skepticism about government institutions is to be expected with a political history ripe with political figures like the Somozas and even Ortega who have used the government to enrich their own lives and political capital. Through informal conversations with many of the respondents, the only administration that met with positive reception was that of former President Violetta Chamorro. With Nicaragua's most recent former president, Arnoldo Alemán, under house arrest for stealing millions from government coffers and Daniel Ortega increasingly under criticism for leaving 
nothing in the government budget upon his departure from office, seeing a democratic government as an institution for the people rather than for those in power is an extremely elusive concept.

\section{Confidence in Government Institutions (CIGIND)}

A second line of inquiry to gauge public attitudes towards governmental institutions, as well as non-governmental institutions, asks respondents to state their level of confidence in each institution. The level of confidence is even more discouraging for the maintenance of democratic political institutions than the belief that their actions are correct. According to Ai Camp $(1999,56)$ the level of confidence one has in the police force is an important indicator for government institutions as a whole, because it is with the police that potential respondents will have the greatest contact. In Nicaragua the police (PEINC7) are the second highest governmental organization in terms of confidence, with only 51 percent of the respondents expressing "little” or "no" confidence. The educational system (PEINC3) receives the highest marks, with only 25.1 percent stating "little” or “no” confidence. The National Assembly (PEINC8) receives the least amount of confidence, with 66.2 percent of the population expressing “little” or "no” confidence. The judicial or legal system (PEINC4) does not fare much better, with 58.4 percent of the respondents expressing "little” or "no" confidence. The respondents also show little confidence in the President, with 53.2 percent of the population claiming "little” or "no" confidence. Finally, when asked about the political system as a whole (PEINC10), 69 percent of the respondents claim "little” or "no" confidence. 
Based on the analysis of these individual variables, there is little confidence in the political institutions. Table 4-11 indexes these variables in the creation of the level of Confidence in Governmental Institutions Index (CIGIND):

Table 4-11: Summary Table for Confidence in Governmental Institutions (CIGIND)

\begin{tabular}{l|cc}
\hline & Frequency & Percentages \\
\hline High Confidence in Governmental Institutions & 14 & 2.6 \\
Medium High Confidence in Governmental Institutions & 86 & 16.1 \\
Medium Confidence in Governmental Institutions & 180 & 33.6 \\
Medium Low Confidence in Governmental Institutions & 142 & 26.5 \\
Low Confidence in Governmental Institutions & 113 & 21.1 \\
Total & 535 & \\
\hline
\end{tabular}

As is evident from the table, 47.6 percent of the respondents demonstrate "low" to “medium-low” confidence in governmental institutions, with 33.6 percent showing “medium” confidence. Moreover, only 18.7 percent of the respondents showed “medium-high" or "high” confidence in governmental institutions. Once again, this is the result of socialized distrust of the government that accompanies civil wars and the indoctrination of oligarchic and autocratic regimes. Another factor contributing to distrust or lack of confidence in governmental institutions has to do with the politicians themselves. Nicaraguans constantly express the distrust they feel about politicians because of the large gap between what a politician promises and what they are able to accomplish. This is due to the unattainable promises made by those running for political office, leading to a rise in expectations. Nicaraguans have extremely high expectations of the government and tend to be consistently disappointed in the ability of the government to meet the demands of society. 
Low confidence levels are primarily directed towards governmental institutions as non-governmental institutions tend to be held in higher regard. When asked to indicate the level of confidence in the church or denomination (PEINC2) the respondent attends, 67.7 percent indicated "quite a lot” or "total” confidence. However, when asked about the Nicaraguan Catholic Church (PEINC1), only 49 percent express "quite a lot" or "total confidence.” This discrepancy appears to be the result of the Nicaraguan Catholic Church's role in politics. Archbishop Obando y Bravo has been a political figure in Nicaragua on both sides, initially as a mediator between the FSLN and the Somozas, and then as an opponent of the Sandinista ideology. The Traditional Catholic Church's role in politics means that its status as a non-governmental institution is called into question. Furthermore, when respondents had converted to other religions, one of the primary reasons given for the conversion was opposition to the political role of the Catholic Church.

Large corporations and major companies (PEINC9) also do not engender high levels of confidence from Nicaraguans, as 56.8 percent of the respondents convey "little" to "no" confidence. Unemployment and underemployment are high, and little benefit is seen from most foreign owned companies due to the Marxist indoctrination during the Sandinista regime viewing them as imperialistic. For example, the Sandinista literacy campaign of 1980, which reduced illiteracy by 50 percent to less than ten percent by 1983, was criticized for Marxist and communist indoctrination due to their goal of raising “political literacy” (Walker 2003, p. 127-128) The unacceptable and exploitive conduct of foreign-owned and multinational corporations, dating back to Cornelius Vanderbilt and William Walker, has added to their poor reception. Corporations receiving high 
praise are Victoria, Toña, and Flor De Caña, which are Nicaraguan-owned and the most visible, sponsoring a huge number of events from volleyball and baseball games to various cultural events.

The press (PEINC5) is a valued institution receiving, the highest approval with 36.7 percent of the respondents stating "high" to "total confidence” and only 30.1 percent expressing "little” to “no” confidence. The press is dominated by its major daily newspapers $\underline{\text { La Prensa }}$, the conservative paper, and El Nuevo Diario, the most widely read, sensational, and Centrist of the papers. This is encouraging because it illustrates the value Nicaraguans place on the freedom of expression and finding a diversity of information.

\section{Support for Gradual Change}

Support for gradual change measures the respondent's patience for the performance of the current democratic regime. Over 85 percent of the population “agreed” or "strongly agreed” that society should be improved gradually through reforms (GCGIR). This is encouraging, as Nicaraguans are expressing patience in allowing the government time to implement its programs. However, Nicaraguans are fearful of a return to civil conflict; thus fear of political decay may be a better explanation for this level of tolerance. The respondent is also asked to state their impression of the level of economic progress occurring in Nicaragua as an indicator of government performance (GCAEP). Thirty-nine percent of the respondents stated Nicaragua was experiencing “bad” or "very bad” economic growth, with 50.3 percent expressing "Más O Menos” economic growth and 8 percent saying "good” or "very good” economic growth. This is 
encouraging as at least a majority of the respondents felt that some progress was being made.

Respondents are also asked about the level of support for rapid change or for some sort of revolutionary action. Support for the actions of revolutionaries is noteworthy, with 23.4 percent showing support and 68.1 percent of the respondents claiming they “disagree” or ”strongly disagree” with the idea of changing society through the actions of revolutionaries (GCSRC). Of the respondents, 87.3 percent feel Nicaraguan society should be defended against al subversive forces (GCDAS). Furthermore, 84.6 percent of the respondents "agree” or "strongly agree" that a priority of the central government should be to maintain stability and order (GCSSO). Once again, these numbers do not necessarily illustrate support for a democratic regime, but a strong desire to avoid political or social conflict. Nicaraguans want the government to provide answers even if that government does not do it as rapidly as the respondents would like. The strong support for stability and order and call for defense against subversive forces trying to upset the current regime demonstrates the Nicaraguan desire for political stability and the lengths to which they would go to ensure it.

\section{Alternative Political Expression Tolerance Index (APIEND)}

Political expression is one aspect of democracy that is well institutionalized in Nicaragua, however, tolerance for all forms of expression is not equally distributed. Of the respondents, 73.4 percent "agree” or "strongly agree" that signing a petition is an acceptable form of political expression (GCPPA). A further 83.4 percent also “agree” or “strongly agree” that attending "lawful” demonstrations is an acceptable form of political expression (GCLDA). Both forms of political expression are relatively common forms 
that, generally, have little potential to erupt into violence or upset the current regime. However, more extreme forms of political expression are frowned upon. Overall, 74.5 percent "disagree” or "strongly disagree” with acceptance of joining a boycott (GCOBA) and 83.5 percent "disagree” that occupying buildings and factories is an acceptable form of political expression (GCPBA)

These variables have been combined in an additive index called the Alternative Political Expression Tolerance Index (APEIND2), as demonstrated in Table 4-12.

Table 4-12: Summary Table for Tolerance of Alternative Political Expression Index (APIEND)

\begin{tabular}{l|cc}
\hline & Frequency & Percentages \\
\hline High Tolerance & 4 & .8 \\
Medium High Tolerance & 79 & 18.8 \\
Medium Tolerance & 276 & 55.1 \\
Medium Low Tolerance & 133 & 26.5 \\
Low Tolerance & 9 & 1.8 \\
Total (N) & 501 & \\
\hline
\end{tabular}

Of the respondents, 55.1 percent exhibit a "medium” level of tolerance, while 28.3 percent have "medium-low" or "low" levels of trust. These low levels are driven by the lack of tolerance in extreme forms of expression. Overall, tolerance of pacific forms of expression is high, but once the possibility of confrontation emerges, tolerance levels plummet. A problem with the study is that a boycott in Nicaragua essentially means a strike rather than refusal to buy a product or use a service as an expression of political beliefs. The potential for political violence during a strike is believed to be high, according to the respondents.

Openness of Political Participation Index (OPINDX)

A third line of inquiry asks respondents to indicate their level of agreement with the rights of individuals expressing negative views about government to participate in the 
political system. Overall, 56.5 percent of the respondents "agree” with their right to vote (GCSVV) and 75.8 “agree” with the right to hold lawful demonstrations for individuals who have only negative things to say about government (GCSSD). Furthermore, 68.1 percent of the respondents at least "agree” with the right of people expressing negative views about the government to make public appearances on television for the purpose of expressing their views (GCSRS). From this evidence it is clear that the majority of Nicaraguans agree with the rights of individuals with negative attitudes toward government to express themselves. However, when it comes to allowing them to run for political office, Nicaraguans are less tolerant. A minority, 44.4 percent of the respondents, “disagree” or "strongly disagree” with the right of individuals with negative attitudes toward the government to run for public office, with 48.7 percent of the respondents believing these individuals should have the right (GCSPO). Nicaraguans are very tolerant when it comes to expression but the desire for political stability will at times override individual rights, thus providing some support for the use of oppressive measures. As a whole, Table 4-13 shows an index of political tolerance for those expressing negative views toward government.

\section{Table 4-13: Openness of Political Participation for Those Expressing Negative} Views (OPINDX)

\begin{tabular}{l|cc}
\hline & Frequency & Percentages \\
\hline High Levels of Openness & 76 & 13.4 \\
Medium High Levels of Openness & 260 & 45.8 \\
Medium Levels of Openness & 116 & 20.4 \\
Medium Low Levels of Openness & 111 & 19.5 \\
Low Levels of Openness & 5 & .9 \\
Total & 568 & \\
\hline
\end{tabular}

Table 4-13 shows that 59.2 percent of the respondents exhibit "high” or "medium- high" levels of openness in the political system for those expressing negative attitudes toward 
the government. In the experience of the author, most Nicaraguans were critical of the government, but confident in the regime and their rights to criticize. Many interviews went longer than an hour as respondents were eager to express their feelings toward government, both positive and negative. Both the evidence and research experience demonstrates that freedom of expression is a well-institutionalized belief in the political structures; however, given the history of political violence in Nicaragua most respondents expressed less tolerance for political expression that could result in civil unrest. It is a delicate balance Nicaraguans carry in terms of the political values to provide the freedom for expression but also the need for stability by limiting some liberties to ensure order in the nation.

\section{Control Variables}

\section{Economic Rank (DIINF)}

Of the 602 respondents, 437 knew their personal monthly income (DIINC) and 430 knew their family's monthly income (DIINCF). Based on these responses the average personal monthly income (DIINC) among the sample population is 2,291.37 Córdobas per month or $\$ 152.76$ (U.S.). ${ }^{18}$ The average family income per month (DIINCF) was 4,521.56 Córdobas or \$301.44 (U.S.) per month. ${ }^{19}$ The respondents are asked to provide a "minimum income" to control for observer intervention. Nicaraguans working in the informal sector, like commerciantes, and many in the formal economy, such as transportistas, may have inconsistent monthly incomes due to fluctuations in the market from seasonal tourists or weather conditions affecting numbers of consumers.

\footnotetext{
${ }^{18}$ Monthly personal income (DIINC) is translated into U.S. dollars based on a 15.00 Córdobas for each \$1. This was the exchange rate during the majority of the field research in the spring and summer of 2003.

${ }^{19}$ According to the CIA World Factbook (2004) GDP per capita (PPP) is $\$ 2,300$. However, according to the 2001 Country Reports on Economic Policy and Trade Practices released by the U.S. Department of States, February 2002, finds the GDP per capita in real U.S. Dollars to be $\$ 468.00$.
} 
Underrepresented in this research may be the extreme ends of the economic spectrum. The wealthy were extremely difficult to access as it was challenging to negotiate an interview through their domestic or security employees. On the other end of the spectrum, urban impoverished neighborhoods proved too dangerous due to increased gang activity, making assistance in these barrios impossible to find. There are now a total of 62 gangs in urban Nicaragua with over 1000 members, which is small in comparison to 14,000 members in Guatemala, 10,500 in El Salvador, and 36,000 in Honduras (Rogers 2004). The rise in gang activity has been attributed to an increased number of expelled Nicaraguans importing the "gang lifestyle" from U.S. cities like Miami and Los Angeles, as well as disaffection among the youth brought on by the processes of "democratization" and "demilitarization” occurring in the wake of Central American civil wars (Rodgers 2002; Lydersen 2004). ${ }^{20}$

\section{Table 4-14: Summary Table for Minimum Family Monthly Income (DIINF)}

\begin{tabular}{l|cc}
\hline & Frequency & Percentages \\
\hline $8001+$ C (Upper Income) & 60 & 12.5 \\
6001 - 8000 C. (Upper Middle Income) & 15 & 3.1 \\
4001 - 6000 C. (Middle Income) & 67 & 13.9 \\
2001 - 4000 C. (Middle Lower Income) & 145 & 30.1 \\
0 - 2000 (Lower Income) & 194 & 40.1 \\
Total (N) & 481 & \\
\hline
\end{tabular}

Table 4-15 shows 40.1 percent of those respondents, who provided a monthly family income, were in the "Lower" economic class, with an additional 30.1 percent answering in the "Middle-Lower" economic class. These respondents have an average monthly

\footnotetext{
${ }^{20}$ The researcher was unable to find research assistants who would enter some of the more impoverished neighborhoods due to the fear of gangs.
} 
family income of less than $\$ 267$ per month. ${ }^{21}$ With an average household containing 6.12 (DINOP) people, each individual receives around \$43 per month for all living expenses.

While income is an important indicator of economic base or class, other factors are important for quality of life. One interesting and surprising aspect of Nicaraguan life is the large numbers of homeowners. Of the respondents providing answers, an astounding 84.4 percent own their own house, with only 14.8 percent renting (DIOWN). High homeownership rates are attributed mainly to the redistribution policies of the Sandinistas and many generations living in the same household, shown through the large numbers of people per household. The largest number of people in a single household was 23, and 24.5 percent of the households had more than 10 people (DINOP). Some of these numbers were astounding, given the majority of houses visited consisted of only one or two rooms divided by makeshift walls. For example, 84.9 percent of the houses had roofs made of aluminum sheets (DIROF), and 46.9 percent had floors made of dirt or concrete (DIFLR). Household luxuries are rare, with a minority 48.1 percent of the respondents owning telephones (DITEL) and small majority of 50.8 percent owning refrigerators (DIREF).

One comfort enjoyed by almost all Nicaraguans is television, as 95.3 percent (DIHTV) of the respondents were observed to have television sets. Even in houses without electricity, it was common to find a small black and white set connected to a large battery. Television viewing is a family activity and telenovelas (Latin America’s version of soap operas), variety, and evening news programs are particularly popular. Age (DIAGE1)

\footnotetext{
21 This figure was created by dividing 4000 Córdobas by 15 (Exchange Rate) to create an income in US Dollars. This is not Purchase Power Parity.
} 
Theoretically, age structure is an important explanatory variable for participation in civil society. For example, Putnam’s (2000, 247-276) analysis of civil society in the United States found that participation varied greatly by generation, with the World War II generation being the most active. The Nicaraguan age structure is vastly different than the United States, and the discontinuous political development experienced by Nicaragua's older generations may produce a dissimilar view of civil society. According to the CIA World Factbook (2004), 38.5 percent of the population are below the age of 14; 58.9 percent are between the ages of 15 and 64; and 3 percent are above the age of 65, with an overall median age of 20.2. For the purposes of this research and in keeping with Internal Review Board protocol, all respondents were over the age of 18, with a mean age of 39.34 and median age of 37 (DIAGE). ${ }^{22}$ As Table 4-15 shows, respondents over the age of 62 made up 9.5 percent of the population, meaning the age structure may be skewed to overrepresent the older population. Regardless, a majority, 55.1 percent, are below the age of 40 and an overall 32.1 percent are between 18 and 28 years of age.

\begin{tabular}{l|cc}
\multicolumn{3}{c}{ Table 4-15: Summary Table for Age (DIAGE1) } \\
\hline & Frequency & Percentages \\
\hline $1985-1975$ / 18-28 years old & 193 & 32.1 \\
$1974-1964$ / 29-39 years old & 138 & 23 \\
$1963-1953$ / 50-40 years old & 129 & 21.5 \\
$1952-1942$ / 51-61 years old & 84 & 14 \\
$1941+$ / 62 + years old & 57 & 9.5 \\
Total (601) & 601 & \\
\hline
\end{tabular}

The surveys were conducted almost exclusively during weekdays meaning that those beyond their productive working ages may be overrepresented. Women may also be

\footnotetext{
${ }^{22}$ Median year born is 1966 and Mean year born 1963 (DIAGE). $($ Median = 1966-2003; Mean = 19632003)
} 
slightly overrepresented, as according to the CIA World Factbook (2004) women make up 50 percent of the overall population and this research found women to compose 51 percent of the sample population. It was originally believed overrepresentation of women would be the result of conducting surveys during work hours where in traditional societies women are much less likely to enter the formal workforce. However, high underemployment rates and limited hours of work means that even working individuals were likely to be in the residence at any point and time.

\section{$\underline{\text { Education Level (DIEDU) }}$}

Educational attainment through public institutions became a right under Article 58 of the 1990 Constitution, where it had previously been a privilege. Though the 1990 Constitution (Article 58) provides for free public education, the education is hardly free. For the average Nicaraguan attending a public school, costs run about $\$ 100$ U.S. dollars per year for uniforms and books, not to mention the loss of income from having a family member working in the informal economy. ${ }^{23}$ Table 4-16 shows the educational attainment of the sample population.

Table 4-16: Summary Table for Educational Attainment (DIEDU)

\begin{tabular}{l|cc}
\hline & Frequency & Percentages \\
\hline Post - University & 8 & 1.3 \\
University / Technical & 178 & 29.7 \\
Secondary & 230 & 38.3 \\
Primary & 139 & 23.2 \\
No School & 45 & 7.5 \\
Total (N) & 601 & \\
\hline
\end{tabular}

\footnotetext{
${ }^{23}$ The research assistant hired for this research, an intelligent young man, had dropped out of the $9^{\text {th }}$ grade claiming no real need for education because of the powerlessness in finding work and the inability to raise the necessary funds needed for educational attainment. Paid 100 Córdobas per day, or roughly \$6.67 U.S. dollars made him the strongest contributor to the family income, but still not sufficient to ensure returning to school, especially given the temporary nature of his employment.
} 
Of the 45 respondents who never received any formal education, 62 percent were above the age of 50. Furthermore, of the 184 respondents having a primary education or less, 48.4 percent were above the age of 50 . This is significant, as overall respondents over the age of 50 make up only make up 23.5 percent of the sample population. Though the younger generations have attained greater educational achievement due to increased access to educational institutions under the Sandinistas and the democratic regime in place since 1990, educational attainment as a proportion of society has begun to decline in recent years, as shown below.

The majority of the Nicaraguan population is young and educated. Given these two facts, it would appear that this younger generation is in the best position to develop Nicaragua into stable, democratic state. However, the field experience also brings to light the difficulties these same educated youth must cope with in a depressed economy where 50 percent of the population lives below the poverty line (CIA World Factbook, 2004). The disaffection of educated individuals unable to find the work in the disciplines they were trained is sending a message to those approaching and enrolled in secondary education that the time and expense of education may not be worth the immediate economic relief provided to larger family units by working in the informal economic sectors selling candy, fruits and nuts by the unit. As a result the number of students dropping out of educational institutions has been rising over the last decade.

According to World Bank Statistics (2003) the level of educational attainment among people 15 to 19 years of age to the proportion of this total age group plummets from 90 percent attending the first grade to a mere 23.9 percent reaching the ninth grade, suggesting high drop out rates. Between the first and ninth grades among people ages 15 
to 19,66 percent of the population drop out of school, compared to 48 percent of those between the ages of 20-29; 50 percent between the ages of 30 to 39; and 49 percent between the ages of 40 to 49 . The overall numbers receiving educational opportunities has risen, but the proportion of educational attainment between age groups finds that drop out rates are much higher today than among previous generations. This disaffection could have negative affects on both civil society and the health of democratic electoral mechanisms in the long run. 


\section{Chapter Five}

\section{Introduction}

Chapter Five examines religious affiliation and levels of religiosity in Nicaragua. It begins with an investigation of denominational affiliations and a discussion of the difficulties categorizing individuals by denomination. Second, a number of variables are explored to determine whether religious denomination and religiosity, the importance of God in one's life, are significant for participation in civil society and support for the maintenance of democratic institutions.

The second section of the chapter is a multivariate analysis of religious denominations and religiosity and the degree to which religion is explains the types and forms of civil society at work in Nicaragua today. Religiosity and religious denominations are compared with age, education, and economic level to determine whether there are any significant relationships with the creation of a civil society capable of establishing and maintaining democratic political institutions.

\section{Religious Denomination in Nicaragua}

The trend away from Catholicism toward religious alternatives, such as Evangelical Protestantism and Pentecostalism is increasing throughout Latin America and has also become a force in Nicaragua. Table 5-1 reveals the trend toward Evangelical Protestantism in the survey is on track with current estimates of its growth. ${ }^{24}$ The 2000 census data in Nicaragua estimated the Evangelical Protestant population to be 15 percent of the total population. ${ }^{25}$ According to the survey, the movement continues its growth with 17.4 percent of the respondents claiming to be Evangelical Protestant in

\footnotetext{
${ }^{24}$ See Stoll (1993 p.337) for an estimation chart through 2010

${ }^{25} 2000$ census data provided by U.S. Dept. of State, http://www.state.gov/g/drl/rls/irf/2002/14052.htm
} 
2003. This 17.4 percent does not include general Protestants, Pentecostals, Baptists, Jehovah's Witnesses, Seventh Day Adventists, Mormons, or other non-Catholic Christian denominations, which make up an additional 8.8 percent of the population. Overall, 29.6 percent of the respondents claim to be non-Catholic, with .2 percent of these claiming to be Muslim and 3.3 percent espousing no religious affiliation. ${ }^{26}$ Catholics account for 70.4 percent of the sample population, with 3 percent of those claiming to be members of CEB's. Distinguishing Charismatic Catholics from Traditional Roman Catholics proved to be an impossible task, though a few respondents did claim membership in the Charismatic sects of Catholicism.

Table 5-1: Predominant Religious Denomination (RBPRP)

\begin{tabular}{l|cc}
\hline & Frequency & Percent \\
\hline Traditional Catholic & 406 & 67.4 \\
Protestant & 4 & .7 \\
Evangelical & 105 & 17.4 \\
Baptist & 19 & 3.2 \\
Pentecostal & 7 & 1.2 \\
Mormon & 3 & .5 \\
Seventh Day Adventist & 7 & 1.2 \\
Jehovah's Witness & 12 & 2 \\
Christian Base Community & 18 & 3 \\
Muslim & 1 & .2 \\
Other/None & 20 & 3.3 \\
Total (N) & 602 & 100 \\
\hline
\end{tabular}

One surprise in the data is the small Pentecostal population. Alternative data sources, such as the World Christian Data Base, estimate the Nicaraguan Pentecostal population in 2005 to be seven percent of the Christian population. The denominational

\footnotetext{
${ }^{26}$ Other religious denominations may be present in Nicaragua. The question asked the respondent to provide his or her own religious denomination. The respondents were not shown a list of religious denominations.
} 
figures on Table 5-1 show a lower number of Pentecostal adherents than expected at 1.2 percent. These low numbers may be the result of a problem selecting the sample population; the method for discerning denominational affiliation; or simply that the Pentecostal movement has not taken hold in these parts of Nicaragua as it has throughout the rest of Latin America. Pentecostalism has been a staple of conversion in South American countries like Brazil, where evangelicals of Pentecostal origin make up ten percent of the total population. ${ }^{27}$ According to the World Christian Database, Pentecostalism is also popular in Central American, where in El Salvador the Pentecostal population is 7.34 percent of the Christian population, 7.65 percent in Guatemala, 7.3 percent in Honduras, 12.8 percent in Panama, and 6.3 percent in Costa Rica. However, in all of these countries Evangelical Churches are the most popular non-Catholic alternative denomination. ${ }^{28}$

Due to small populations among Pentecostals, Jehovah's Witnesses, Mormons, Seventh Day Adventists, and Baptists, as well as those who claimed to be "Protestant", it is difficult to make statistical statements about the individual denominations. A second variable codes religious affiliation as "Traditional Catholics", "Progressive Catholics", and a compilation of all other non-Catholic Christian denominations coded as "Evangelical” (RBPRP4). This variable is used to provide an overall examination of the

\footnotetext{
${ }^{27}$ Religious demographic statistics on Brazil down loaded from the Brazilian Institution for Geography and Statistics (IBGE) at http://www.ibge.govand are the results from the 2000 Census. (http://www.ibge.gov.br/home/estatistica/populacao/censo2000/populacao/religiao_Censo2000.pdf) ${ }^{28}$ Religious demography for El Salvador, Guatemala, Panama, Honduras and Costa Rica are calculated from statistics provided by World Christian Data Base (WCD)at The Center for the Study of Global Christianity Gordon-Conwell Theological Seminary found at www.worldchristiandatabase.org The WCD found Nicaragua to have a Pentecostal population of seven percent, while this research found a much smaller population. The Evangelical population in Nicaragua according to the WCD is eleven percent while this research estimates the Evangelical population to be 17.4 percent. The WCD provides estimates for the population in 2005.
} 
movement away from Catholicism. ${ }^{29}$ Theoretically, this is not a major problem as these denominations and churches are similar in their independent structure and the basis for conversion is similar across all denominations. According to Stoll, the term "evangelical” in Latin America “...connotes a theological conservative, who emphasizes the Bible, personal salvation, and evangelism ...[and] can refer to any non-Catholic Christian (Stoll 1993, 4).” Table 5-2 shows the percentages of Traditional Catholic respondents in contrast with Progressive Catholics, and Evangelical Protestants.

Table 5-2: Primary Religious Provider (RBPRP4)

\begin{tabular}{l|cc}
\hline & Frequency & Percent \\
\hline Traditional Catholic & 406 & 67.4 \\
Progressive Catholic & 18 & 3 \\
Evangelical & 157 & 26.1 \\
Other & 21 & 3.5 \\
Total & 602 & 100 \\
\hline
\end{tabular}

Examination of the sample population finds 67.4 percent of the respondents assert Traditional Catholicism as their primary religious provider, with 26.1 percent pronouncing an alternative Christian denomination.

A significant issue in studying the effects of denomination in a transitional religious environment is the process of conversion, which is often lagged and incomplete. Table 5-3 measures the level of conversion by asking respondents to state whether they are members of more than one denomination. If respondents claim to be a member of more than one denomination (RBMOD), then the conversion process is incomplete. The respondent has either not fully embraced their new religious affiliation or not totally given up the beliefs of their previous religious affiliation. As a result, the effects of a

\footnotetext{
${ }^{29}$ For the purposes of multiple regression analysis RBPRP4 was divided into four dummy variables: Traditional Catholics (CATDUM), Progressive Catholic (CEBDUM), Evangelical (EVANDUM) and Other (OTHDUM)
} 
particular denomination may not be fully socialized among newer converts. Table 5-3 provides a breakdown of membership in more than one denomination.

Table 5-3: Member of More Than One Denomination (RBMOD)

\begin{tabular}{l|cc}
\hline & Frequency & Percent \\
\hline Member of only one Denomination & 561 & 93.8 \\
Member of More than one Denomination & 37 & 6.2 \\
Total & 598 & 100 \\
\hline
\end{tabular}

As Table 5-3 demonstrates roughly 6.2 percent of the sample population claim to be a member of more than one denomination, with 93.8 percent claiming membership in only one denomination. Of these, 6.2 percent (RBMOD) claiming membership in more than one denomination, 66.1 percent, or 4.2 percent of the sample population, claim Catholicism as their secondary religious provider (RBPOR). Therefore, of the 26.1 percent of the sample population claiming conversion to a religion outside of Catholicism (RBPRP3), 4.2 percent (RBPOR) still maintain an association with Catholicism in one of its forms Traditional, Progressive, or Charismatic. This is significant as it illustrates the process of conversion is not definite and association with one religious denomination may not be mutually exclusive with association to other denominations. A lag effect or learning curve occurs within conversion; it takes time for converts truly to understand and embrace their new religion, and some may return to their previous denomination.

A follow-up question asks the respondent to state their reason for conversion (RBRFC) to gain insight into the movement away from Catholicism toward more “Evangelical” Protestant denominations. Respondents often expressed more than one reason for their conversions, which made coding their responses difficult. For the sake of analysis, the first response given was assumed to be the respondent's primary reason for conversion. The responses were summarized and coded as: (1) "invited by friends or 
family"”; (2) "better answers to social problems such as alcoholism”; (3) "better presentation of scripture and relationship with God"; (4) "Catholic Church is too political”; (5) "Dislike of Catholicism”; (6) and "Personal Decision”. Table 5-4 provides an itemization of the major reasons for conversion among the respondents.

Table 5-4: Reason For Conversion (RBRFC)

\begin{tabular}{l|cc}
\hline & Frequency & Percent \\
\hline Invited /Family & 15 & 14.7 \\
Answers to Social Problems & 4 & 3.9 \\
Presentation of Scripture and God & 54 & 52.9 \\
Political Involvement of Catholic Church & 5 & 4.9 \\
Dislike of Catholicism & 6 & 5.8 \\
Personal Decision & 18 & 17.6 \\
Total (N) & 102 & 99.3 \\
\hline
\end{tabular}

NOTE: The sample population for this table consists of only non-Catholics who provided a reason for conversion is a percentage of the whole population.

Of those who have converted from Catholicism to another denomination, 14.7 percent stated conversion was born out of an invitation by friends or family. A further 3.9 percent were looking for answers to social problems such as alcoholism and drug abuse. The majority of respondents, or 52.9 percent, felt that the presentation of the scripture and / or relationship with God was enhanced in Evangelical denominations. Informally, many claimed that Evangelical worship services were more personal and enjoyable with smaller congregations. Perks of association with Evangelical denominations included more personal relationships with "clergy", the inclusion of

\footnotetext{
${ }^{30}$ Family may also mean that the respondent was born to parents associated with Evangelical Protestant denominations and therefore may have been raised Evangelical Protestant.
} 
music, and greater opportunity and acceptance of overt expressions of faith during worship services. ${ }^{31}$

Dislike of the Catholic Church's involvement in politics is cited by 4.9 percent as a reason for conversion, and an additional 5.9 percent expressed overt dislike for the Catholic Church. Finally, 17.6 percent claimed that their conversion was the result of a personal decision. These respondents usually could not settle on a particular reason or did not want to express one.

\section{$\underline{\text { Religiosity in Nicaragua }}$}

Religiosity is a complicated construct with no less than three separate concepts requiring measures. Inglehart and Norris (2004) define religiosity as “... religious participation, values and beliefs at [the] individual level” (Chapter 2 p. 6). Accordingly the concept of religiosity (RELIGIOSITY) in this research is based on measures of the level of religious participation (RBLRP), religious value (RBLRV), and religious belief (RBLRB). The level of religious participation (RBLRP) measures the frequency the respondent participates in religious consultation for guidance. The level of religious value (RBLRV) measures the level of devoutness the individual places on the product of consultation and the Bible as the irrefutable word of God. The greater the value respondents place on the results of religious of consultation, the greater respondents use religion for daily guidance. Level of religious belief (RBLRB) gauges the breadth of concepts used by respondents during religious participation. The greater the number of concepts referenced when consulting religion for guidance, the greater the adherent's

\footnotetext{
${ }^{31}$ The statements regarding the benefits of conversion to Evangelical Protestantism are not part of the data set but an observation from discussions with respondents and other Nicaraguans.
} 
reliance on religion. Finally, the greater the number of religious concepts referenced, the less room for alternative information or forms of guidance to be accessed.

The goal of this research is to explore the relationship between religion and civil society at the individual level; thus two additional measures have also been constructed. The first is a measure of respondent beliefs regarding the role of religious institutions in the public/political sphere (RBCRS). To operationalize the variable, respondents are asked to indicate on which issues they believe it is appropriate for "the Church" to make public statements. Secondly, an assessment of how well religious organizations are responding to the needs of society (RBCPA) has been generated to provide a measure of performance. These measures (RBCRS and RBCPAI) are designed to grasp the extent respondents want religious organizations to participate in civil society and how the respondent perceives their success.

\section{Level of Religious Participation (RBLRP)}

This study chose to measure participation through the respondent's use of God for day-to-day guidance, a significant dimension of participation. If an individual consults God daily to make decisions and find answers, then each day the respondent is praying or participating in worship and practicing religion. This variable helps control for the disparity in participation that might occur as a result of religious affiliation. The respondent was asked how often they pray outside of religious services (RBPOR).

Of the sample population, 54 percent claim they “always” pray outside of religious services; 26 percent responded "sometimes”; with the remaining 19.3 percent responding “almost never”, “only in times of crisis”, and “never.” Given that 80 percent of the population “always” or "sometimes” communicate with God demonstrates, at least 
on the individual level, participation is strong. Still, a large segment of the sample population at 19.3 percent rarely consults God, which is a significant number not participating. Correlations between the levels of religious participation (RBLRP) showed a significant relationship between Evangelicals, but not between Traditional Catholics, Progressive Catholics, nor Non-Christians.

\section{Level of Religious Value (RBLRV)}

The second religiosity variable measures the value of religion in one's life by asking the respondent to measure the importance of God in their life on a 10-point Likert Scale (RBIGL). Results for this question showed little variation as 90.7 percent of the respondents state God is of "total importance (10)" in their lives. Additionally, 4 percent found God “extremely important (9)” and 3.7 percent stated God is 'very, very important” (8). Observer interference may have played a large role in the limited variation as many respondents want to demonstrate faith, a noble characteristic in Nicaraguan society. Furthermore, according to Inglehart and Norris (2004), religiosity levels in traditional societies are going to be much higher because they are not following the trend towards secularism in industrial societies, due to poor "human development". Inglehart and Norris (2004, Chapter 2, p. 4) define "human development” as “...a complex process of social transformation, including changes in the economy with the shift from agricultural production to industrial production and the rise in the service sector”. ${ }^{32}$

An alternative measure for the value of religion asks the respondents to state their level of agreement with whether “...the Bible contains the word of God and

\footnotetext{
${ }^{32}$ For definition of human development see Ronald Inglehart and Pippa Norris Sacred and Secular: Religion and Politics World Wide New York: Cambridge University Press (In press, publication Fall 2004 downloaded from http://ksghome.harvard.edu/ pnorris/).
} 
everything in it is literally true (RBBLT)". Responses varied little, with 46 percent “strongly agreeing” and 44.8 percent "agreeing”, for an overall 90.8 percent agreeing that the Bible contains the "Word of God" and is literally true. A minority population of 4.1 percent state they "neither agree nor disagree” and 5.1 percent either "disagree” or “strongly disagree.” From this variable it is evident that Nicaraguans take the Bible as truth and thus its contents are of value in their daily lives.

Replies were much more varied when asked whether “...eternal life was only possible for those who believe in Jesus Christ as God and Savior (RBHBG).” An overall 75.2 percent of the respondents agreed with the statement, but only 21.3 percent "strongly agreed”. This indicates that while an overwhelming majority believe the Bible to be literally true (RBBLT), they are less certain that eternal life is only for those who believe in Jesus Christ as Lord and Savior (RBHBG). These results highlight a common disjuncture between religious beliefs as a general concept and the religious beliefs in practice. It is easy to state everything in the Bible is literally true. However, when confronted with a specific Biblical concept, such as the First Commandment ${ }^{33}$, respondents are less certain because their answer could have consequences for their own lives. If the respondent is unsure whether he or she accepts "accepts Jesus Christ as Lord and Savior”, then they are less likely to deny eternal life to themselves or others. Thus, the Bible as a concept can be accepted easily, but applying specific Biblical concepts to one's life takes a stronger faith in religion. The cognitive dissonance associated with religion occurs everywhere and is not specific to Nicaraguans.

Finally, 89 percent of the respondents find strength and comfort from religion (RBRSC). This figure is significant because it shows that religion as an overall concept

${ }^{33} 1^{\text {st }}$ Commandment, Verse 3 "Thou shall have no other God before me" 
provides the respondent with comfort and strength, irrespective of its application.

Religion, overall, is a positive construct in Nicaraguan society as a place to find answers, as well as escape from the hardships of everyday life.

Level of Religious Belief (RBLRB)

Assessment of religious belief asks respondents if they believe in particular Biblical concepts as read from a list (RBWTB) and illustrated on Table 5-5. Beliefs in particular Biblical concepts are important because they imply the number or breadth of beliefs respondents implement for guidance in daily life. Religious value and religious belief are not mutually exclusive concepts, but differ in one major respect. Religious belief (RBLRB) explores the diversity of religious constructs the respondent applies to life rather than just the value (RBLRV) placed on the broader construct of religion as a whole. An interesting finding in Table 5-5 shows disconnection again occurs between applying positive over negative constructs to daily life.

Table 5-5: "Please indicate whether you believe in any of the following (RBWTB1-9)

\begin{tabular}{|c|c|c|c|}
\hline & "Yes" in Percentages & "No" in Percentages & $N$ \\
\hline God (RBWTB1) & 99.7 & .3 & 598 \\
\hline Life After Death (RBWTB2) & 86.5 & 13.5 & 550 \\
\hline A Soul (RBWTB3) & 95 & 4.9 & 576 \\
\hline The Devil Exists (RBWTB4) & 76.6 & 23.3 & 579 \\
\hline Hell Exists (RBWTB5) & 74 & 26 & 572 \\
\hline Heaven Exists (RBWTB6) & 93.8 & 6.2 & 584 \\
\hline In Sin (RBWTB7) & 98.5 & 1.5 & 601 \\
\hline Resurrection of the Dead (RBWTB8) & 89.1 & 10.9 & 570 \\
\hline Reincarnation (RBWTB9) & 61.9 & 38.1 & 564 \\
\hline
\end{tabular}

Note: Reincarnation is not a Biblical concept but was included as a test of religious knowledge.

As demonstrated by Table 5-5, religious belief is extremely strong in Nicaragua, as every religious concept represented produced a statement of belief by a majority of the respondents. Table 5-5 also uncovers an intriguing trend where respondents have a 
stronger belief in positive attributes of religion over negative. An average of 93.3 percent of the respondents believe in the positive religious attributes of God (RBWTB1), life after death (RBWTB2), a soul (RBWTB3), and the existence of heaven (RBWTB6). In contrast, an average of 83.3 percent of the sample population believe in negative religious attributes like the existence of the devil (RBWTB4), the existence of hell (RBWTB5) and $\sin (\text { RBWTB7) })^{34}$. This disconnection again demonstrates the general construct of religion as positive. In the process of applying religion to one's daily life, the most often used constructs are positive. The greater use of positive religious concepts is evidence of the desire for religion to provide a diversion from social and economic challenges facing citizens in traditional societies as a source of escape.

\section{Role of Religion in Society (RBCRS)}

To gain an understanding of respondents' attitudes toward the role of religion in society (RBCRS) they are asked whether they believe religious organizations can be effective in addressing problems of the community (RBRAP). Overall, 73.9 percent of the respondents "agree" that the "Church" can be effective in addressing problems of the community. The majority of respondents "agreeing” religious organizations are effective in addressing community problems demonstrates the prevalence among the sample population to deem religious organizations as effective social institutions that should retain a major role in society. This is not a great surprise, given the poor economic capacity of Nicaraguan governmental institutions effectively to address larger socioeconomic problems, leaving religious organizations to fill the void.

When respondents are asked whether the religious organizations or churches "they attend" should work to solve social issues (RBSSP), a larger portion of the sample

\footnotetext{
${ }^{34}$ If $\sin$ (RBWTB7) is excluded the average belief in negative religious concepts drops to 75.2 percent.
} 
population at 86.2 percent "agreed" or "strongly agreed". Presented with the broader construct of a generic religious organization, respondents are not as certain about the role of religion in society. However, when discussing the religious organizations respondents are affiliated with, they are more certain about their particular organization's capacity for addressing community problems. This points to an overall attitude regarding religious organizations and church communities as a whole. The greatest level of confidence is directed toward the religious institutions with which respondents are associated. If respondents are engaged with a specific religious organization, they have greater awareness of the activities of that particular organization. Respondents cannot speak for all religious organizations and are less certain other religious institutions should or do play a large role in society. Disjuncture in the role of religion in society between generic and specific organizations shows, at the individual level, reciprocal associational activities are creating institutional confidence in the respondent's religious organization.

To further explore the role of religious organizations in society, respondents are asked to state whether it is appropriate for "the Church" to speak out on certain social issues (RBCRS). These variables, illustrated on Table 5-6, measure the span of issues on which respondents find it appropriate for the Church to be involved. 
Table 5-6: "Should the Church speak out on these issues...(RBCRS)?"

\begin{tabular}{l|ccc}
\hline & Yes (Valid \%) & No (Valid \%) & N \\
\hline Disarmament (RBCRS1) & 69.4 & 30.4 & 575 \\
Problems of Third World (RBCRS3) & 77.4 & 22.4 & 554 \\
Extra Marital Affairs (RBCRS4) & 76.6 & 23.3 & 558 \\
Drug Addiction (RBCRS5) & 92.1 & 7.7 & 594 \\
Alcoholism (RBCRS6) & 90.5 & 8.1 & 594 \\
Unemployment (RBCRS7) & 82.8 & 16.6 & 580 \\
Racial Discrimination (RBCRS8) & 86.2 & 13.6 & 580 \\
Euthanasia (RBCRS9) & 75.2 & 24.8 & 476 \\
Homosexuality (RBCRS10) & 66.1 & 33.7 & 575 \\
Ecology and the Environment (RBCRS11) & 86.6 & 13.4 & 584 \\
Politics and Government (RBCRS12) & 41.8 & 58.2 & 586 \\
Human Rights (RBCRS13) & 93.8 & 6.2 & 597 \\
\hline
\end{tabular}

Note: Opinions about abortion were collected, but due to a mistranslation of the term during the first part of the survey it was omitted.

Judging from these figures, Nicaraguans want religious organizations to play a considerable role in society. Addiction recovery is the most significant moral issue for Church involvement while issues relating to sex, such as homosexuality (RBCRS10) and extra marital affairs (RBCRS4), receive less support for religious involvement. Respondents are also supportive of religious involvement in the public sphere when involvement encompasses employment issues (BRCRS7), disarmament (RBCRS1), problems of the "third world" (RBCRS3), and human rights (RBCRS13).

Respondents are overwhelmingly against religious involvement in "Politics and Government” (RBCRS12). Given the tenuous church and state relationship throughout Nicaragua's chaotic political history, this finding is not astonishing. Contemporary political history illustrates a schizophrenic Church and State relationship. Under the Somoza regime, the Catholic Church split, with "Traditional Catholics” viewed as maintaining the status quo as opposed to the "Progressive Church" professing a doctrine 
of liberation. Under the Sandinista regime, the Catholic Church was again divided, with the "Progressive Church” perceived as creating and maintaining the Revolutionary status quo, as opposed to the “Traditional Catholic Church” seeking greater religious freedoms and separation of Church and State. Fragmentation within the Nicaraguan Catholic Church was also intensified with Progressive clergy playing frontline roles in the revolution and occupying key political positions in the Sandinista Regime (Walker 2004, Sabia 1997, Mulligan 1991). As Deneonandan (2001, p. 449) stated, the Progressive Church's close association with the status quo of the Sandinistas might have been a major cause of its decline. In the wake of the Contra War the Sandinistas introduced policies that hurt the CEB's and the poor in general.

\section{Success of Religious Organizations in Society (RBCPAI)}

Table 5-7 provides an overview of how successful respondents in the study believe religious institutions are when entering into the public sphere in an effort to address social problems. While it is evident respondents want religious institutions to address social problems, the perception of success among religious institutions may translate into positive attitudes toward other social, political, and economic institutions.

\section{Table 5-7: "Is the Church providing adequate answers to ...(RBCPA)?”}

\begin{tabular}{l|ccc}
\hline & Yes (Valid \%) & No (Valid \%) & $N$ \\
\hline Moral needs and problems of the individual (RBCPA1) & 64 & 36 & 578 \\
The problems of family life (RBCPA2) & 72.1 & 27.7 & 587 \\
The spiritual needs of the population (RBCPA3) & 83.3 & 16.7 & 581 \\
Social problems facing the country (RBCPA4) & 65.8 & 34.2 & 573 \\
The financial problems facing individuals (RBCPA5) & 46.9 & 53.1 & 569 \\
Your church provides a sense of community (RBCPA6) & 78.4 & 21.6 & 569 \\
\hline
\end{tabular}

Religious organizations are successful fulfilling their main function as spiritual providers (RBCPA3), according to 83.3 percent of the respondents. Religious institutions 
are also accomplishing their mission as community centers, with 78.4 percent of the respondents claiming their church provides a sense of community (RBCPA6). The sense of community is crucial for the causal relationship put forth by Putnam (2000, 1995, 1993) that reciprocal positive interactions among individuals in a community translates into interpersonal trust and trust in other individual and institutions. This is the production of social capital, a necessary ingredient for a successful democratic polity.

In terms of social (RBCPA4), moral (RBCPA1), and family (RBCPA2) issues, religious institutions are less successful, with 65.8 percent, 64 percent, and 72.1 percent of the respondents claiming the Church is providing adequate answers to these issues. Finally, a minority 46.9 percent of the respondents, believes that religious institutions are providing adequate answers to the financial problems facing individuals (RBCPA5).

\section{Religious Denominations and Civil Society}

The analysis now turns toward an exploration of the effects of religion on the propensity of respondents to participate in civil society, as well as whether the effects of participation, such as attitudes supportive of democratic institutions, are being accrued by respondents. The first section examines the effect of affiliation with particular religious denominations on participation in civil society. This section also explores the secondary effects of civil society participation in terms of providing healthy democratic values necessary for the maintenance of democratic political institutions. The religious denomination variable (RBRPR4) is divided into four dummy variables for multiple regression analysis. Table 5-8 shows the Beta coefficients for the civil society dependent variables and the independent variables of religious denomination as characterized by Traditional Catholic (CATDUM), Progressive Catholic (CEBDUM), Evangelical 
(EVANDUM) and omitted from the list is other religious affiliation (OTHDUM).

Control variables include age (DIAGE1), education (DIEDU), gender (DIGEN), and income (DIINF). 
Table 5-8: Religious Denomination and Civil Society

\begin{tabular}{|c|c|c|c|c|c|c|c|c|c|c|c|}
\hline & $\begin{array}{c}\text { Formal } \\
\text { Civil } \\
\text { Society } \\
\text { (FOCIND) }\end{array}$ & $\begin{array}{c}\text { Informal } \\
\text { Civil Society } \\
\text { Participation } \\
\text { (ICSPIN) }\end{array}$ & $\begin{array}{l}\text { Informal } \\
\text { Civil } \\
\text { Society } \\
\text { Support } \\
\text { (ICSSIN) }\end{array}$ & $\begin{array}{l}\text { Informal } \\
\text { Civil } \\
\text { Society } \\
\text { Total } \\
\text { Index } \\
\text { (ICSTIN) }\end{array}$ & $\begin{array}{c}\text { Political } \\
\text { Efficacy } \\
\text { Index } \\
(\text { POLEF) }\end{array}$ & $\begin{array}{c}\text { Political } \\
\text { Knowledge } \\
\text { Index } \\
\text { (PKIND) }\end{array}$ & $\begin{array}{c}\text { Interpersonal } \\
\text { Trust Index } \\
\text { (IPTRUST) }\end{array}$ & $\begin{array}{c}\text { Openness of } \\
\text { Political } \\
\text { Participation } \\
\text { Index } \\
\text { (OPINDX) }\end{array}$ & $\begin{array}{c}\text { Acceptance } \\
\text { of } \\
\text { Alternative } \\
\text { Political } \\
\text { Expressions } \\
\text { (APEIND) }\end{array}$ & $\begin{array}{c}\text { Confidence in } \\
\text { Governmental } \\
\text { Institutions } \\
\text { (CIGIND) }\end{array}$ & $\begin{array}{c}\text { Belief That } \\
\text { Government } \\
\text { Actions are } \\
\text { Correct } \\
\text { Index } \\
\text { (BGAIND) }\end{array}$ \\
\hline $\begin{array}{l}\text { Catholic } \\
\text { Dummy } \\
\text { Variable } \\
\text { (CATDUM) }\end{array}$ & -.070 & .126 & $-.209 *$ & .000 & .122 & -.095 & .129 & -.123 & .094 & $.233^{*}$ & .103 \\
\hline $\begin{array}{l}\text { CEB Dummy } \\
\text { Variable } \\
\text { (CEBDUM) }\end{array}$ & .059 & $.174 * * *$ & .047 & $.144^{* * *}$ & $.114^{*}$ & -.017 & $.117^{*}$ & -.005 & .044 & $.147^{* *}$ & .065 \\
\hline $\begin{array}{l}\text { Evangelical } \\
\text { Dummy } \\
\text { Variable } \\
\text { (EVANDUM) }\end{array}$ & -.044 & .188 & -.068 & .106 & .069 & -.028 & -.001 & -.123 & .082 & .098 & .056 \\
\hline $\begin{array}{l}\text { Gender } \\
\text { (DIGEN) }\end{array}$ & $.226 * * *$ & $.081 *$ & -.039 & .046 & .009 & $.238 * * *$ & .059 & $.211^{* * *}$ & -.045 & -.024 & $.132^{* *}$ \\
\hline $\begin{array}{l}\text { Education } \\
\text { (DIEDU) }\end{array}$ & $.270 * * *$ & $.210 * * *$ & $.265^{* * *}$ & $.268 * * *$ & -.074 & $.216^{* * *}$ & .051 & $.185^{* * *}$ & $-.105^{*}$ & -.093 & .013 \\
\hline $\begin{array}{l}\text { Age } \\
\text { (DIAGE1) }\end{array}$ & $.108^{* *}$ & $.231^{* * *}$ & $.209 * * *$ & $.259 * * *$ & -.039 & .014 & .018 & .023 & .045 & $-.127 * *$ & -.0147 \\
\hline $\begin{array}{l}\text { Monthly } \\
\text { Family } \\
\text { Income } \\
\text { (DINNF) }\end{array}$ & -.039 & .017 & .033 & .022 & -.047 & .071 & -.031 & $.085^{*}$ & -.036 & -.076 & -.067 \\
\hline $\begin{array}{l}\text { Adjusted R } \\
\text { squared }\end{array}$ & .111 & .077 & .09 & .103 & -.001 & .117 & -.001 & .095 & .007 & .033 & .025 \\
\hline
\end{tabular}




\section{Religious Denomination and Participation in Formal Civil Society}

An examination of Table 5-8 finds no significant relationships between religious denominations and participation in formal organizations (FOCIND) outside of religious organizations. Gender (DIGEN), education (DIEDU), and age (DIAGE) are all significant indicators of formal civil society participation (FOCIND). Gender (DIGEN) is significant as males are more likely to participate in formal civil society than females. Correlations showed significant relationships between gender and participation in sports or recreation groups, political parties, labor unions, and professional associations.

The majority of participation in formal organizations occur in sports organizations in which a plethora of men's teams exist and very few women's. During the field research the author lived across the street from a sports complex built by a Japanese aid organization that contained a full-length basketball court and a baseball facility with three fields, bleachers, and press boxes. During evenings and weekends the facility was packed with baseball and softball leagues of all ages, as well as frequent basketball tournaments. While ages varied for the numerous leagues, gender did not as no women's leagues or teams were ever observed utilizing the facilities.

Men also dominate participation in labor unions, mainly through transportation cooperatives. In the four months of the field research, the author depended solely on public transportation either by bus or taxi, often four or five times a day. Whether in Managua, Masaya, Granada, or the Pueblos Blancos areas there were only two separate incidents where the driver or the individual collecting fares was female. In other labor unions, like artisan cooperatives, gender was less of a factor. Professional associations and political parties are also men's organizations. Of the respondents claiming to be 
“very active” or "active” members of political parties, 75 percent are men. In regards to professional associations 73 percent of "active” or "somewhat active” members are men. Therefore, concerning formal civil society structures outside of religious organizations, Nicaragua remains a traditional society with men entering into secular formal associational activity with significantly more frequency than women, even after the Sandinista Revolution.

Religious Denomination and Informal Civil Society

Relationships between religious denomination and the variables measuring informal civil society are also illustrated on Table 5-8. Traditional Catholics show a significant negative relationship in support for informal civil society (ICSSIN). Essentially, Traditional Catholics are less likely to donate time, money, or materials to solve problems of the community or one of its members. Progressive Catholics are more likely to participate in informal civil society (ICSPIN) by attending or organizing meetings and donating their work to resolve the problems of the community or one of its members. Evangelicals show no significant relationship between their religious denomination and their propensity to support (ICSSIN) or participate (ICSPIN) in informal civil society.

Other significant indicators of participation and support for informal civil society are education (DIEDU) and age (DIAGE1). The more educated respondents are, the more likely they are to participate and support informal civil society. That is, the educated are more involved in trying to find solutions to community and individual problems. Age (DIAGE1) is a significant indicator as older respondents are more likely to support and participate in finding solutions to community problems or the problems of 
one of its members. The willingness of older generations to participate and support informal civil society appears to be a residual effect of having worked with barrio or neighborhood level organizations during the Sandinista regime. Furthermore, older respondents may have been cognitively responding to Sandinista community organizing because the survey instrument simply asks whether they had participated or supported civil society, not when participation occurred. Informally, many respondents would recall the work they did with community organizations during the Sandinista regime. Furthermore, in Managua many of the barrios are still organized around a neighborhood “jefe” and a committee working on community issues.

Overall, religious denominations are erratic indicators of a person's propensity to support or participate in civil society; but age, gender, and education are stronger predictors. The exception among religious denominations is Progressive Catholicism, which is a positive significant indicator of whether a respondent will participate in informal civil society (ICSPIN). However, this relationship may be fragile, as Progressive Catholics made up only 18 of the 602 total respondents, or 3 percent of the sample population. Furthermore, Progressive Catholicism is vanishing as a religious institution. Interviews in Managua with a number of respondents from Barrio La Luz ${ }^{35}$ found that in 1995 most working class barrios had their own CEB's, but the last ten years has seen a sharp decline in membership. Today, Managua has only one city wide CEB, with infrequent meetings.

\section{Religious Denomination and Effects of Civil Society}

\footnotetext{
${ }^{35}$ Barrio La Luz is a working class neighborhood in the center of Managua. It is also know as 14 de Juneo which was its official name during the Sandinista Regime. The author lived in this neighborhood in 1995 and attended meetings with the CEB. However, today that CEB does not exist on the neighborhood level, but a few of the originators still attend the Managua wide CEB.
} 
The absence of a major effect of denomination, especially among Traditional Catholics and Evangelicals, on the respondent's propensity to support and participate in civil society carries over into the effects of civil society. Associational activity occurring both within religious denominations are not significant indicators of democratic values capable of maintaining democratic institutions. As shown on Table 5-8, and contrary to the hypotheses, involvement with Evangelical denominations (EVANDUM) and the associational activity occurring within those organizations is not an indicator of respondents' level of political efficacy (POLEF), interpersonal trust (IPTRUST), or political knowledge (PKIND). Being Evangelical is also not an indicator of whether the respondent believes in an open political system (OPINDX), acceptance of alternative political expressions (APIEND), confidence in governmental institutions (CIGIND), or a belief that governmental actions are correct (BGAIND).

On the other hand, being a Traditional Catholic (CATDUM) is a positive significant indicator of whether respondents have confidence in governmental institutions (CIGIND). That is, Traditional Catholics have greater confidence in governmental institutions than Evangelicals.

Surprisingly, Progressive Catholicism (CEBDUM) also produces a positive significant relationship with confidence in governmental institutions (CIGIND). A common perception is that Progressive Catholicism (CEBDUM) creates an antityrannical form of civil society, which it in no doubt did before and during the Sandinista Revolution. Today the civil society produced within these denominations appears to be more along a democratic civil society as demonstrated by the confidence held in governmental institutions (CIGIND). 


\section{Religiosity and Civil Society}

With religious denomination as an explanation for civil society providing only minor insight, the research now turns toward the concept of religiosity. As noted earlier, religiosity is the culmination of the level of religious belief (RBLRB), value (RBLRV), and participation (RBLRP). This research utilizes these concepts but also adds two other constructs of religiosity. The first corollary construct of religiosity is an examination of the role respondents believe religious organizations should play in society (TOTAL). The second alternative concept is an exploration of the perceived success of religious organizations in their societal roles (RCBPAI). These two additional aspects of religiosity are significant in economically challenged societies, as religious organizations often play a large societal role (Inglehart and Norris 2004). As found in Chapter Four, most Nicaraguans expect religious organizations to play a major role in society.

Table 5-9 shows the effect of religiosity on civil society. ${ }^{36}$ The combination of religious belief (RBLRB), value (RBLRV), and participation (RBLRP) as an index of religiosity variable (RELIGIOSITY) shows no significant relationship with any of the dependent civil society variables. However, two significant relationships exist between religiosity (RELIGIOSITY) and the effects of civil society. Religiosity (RELIGIOSITY) is an indicator of a person's level of interpersonal trust (IPTRUST) and confidence in governmental institutions (CIGIND). The greater the respondent's religiosity, the greater their level of interpersonal trust (IPTRUST), or the more they trust people in general. Furthermore, the greater a person's religiosity, the greater the confidence they have in governmental institutions (CIGIND). Accordingly, religiosity may be significant in

\footnotetext{
${ }^{36}$ The religiosity variable used here is an additive index of the respondents level of religious belief, participation, and value (RBLRP + RBLRB + RBLRV)
} 
creating supportive democratic attitudes. It must be noted that the adjusted R squared for the models where religiosity is a significant indicator are low. As with religious denominations, the major indicators for participation and support of civil society and the effects accrued through involvement in civil society are level of education, age, gender and income level.

Religiosity (RELIGIOSITY) as an index variable may lack the explanatory power desired, but, unpacked into its three major elements, its explanatory value increases as shown by Table 5-10. Formal civil society participation (FOCIND), is greatly explained by education (DIEDU), age (DIAGE1), and gender (DIGEN), but a significant negative relationship also is found with the level of religious belief (RBLRB). Respondents who exhibit high levels of religious belief (RBLRB) are significantly less likely to participate in formal civil society (FOCIND) outside of religious organizations. The greater one believes in religion, the less likely they use or need secular civil society institutions such as labor unions, sports organizations, political parties, etc.

Further examination of Table 5-10 shows a significant negative relationship between the levels of religious belief (RBLRB) and the respondent's propensity to participate in or support informal civil society (ICSTIN). The greater the level of religious belief (RBLRB), the less likely respondents will work to find a solution to community problems or the problems of one of its members. Respondents in these cases may be defining community as those individuals within the immediate geographical proximity to their residence and not their religious community. 
Table 5-9: Religiosity and Civil Society

\begin{tabular}{|c|c|c|c|c|c|c|c|c|c|c|c|}
\hline & $\begin{array}{c}\text { Formal } \\
\text { Civil } \\
\text { Society } \\
\text { (FOCIND) }\end{array}$ & $\begin{array}{c}\text { Informal } \\
\text { Civil Society } \\
\text { Participation } \\
\text { (ICSPIN) }\end{array}$ & $\begin{array}{l}\text { Informal } \\
\text { Civil } \\
\text { Society } \\
\text { Support } \\
\text { (ICSSIN) }\end{array}$ & $\begin{array}{l}\text { Informal } \\
\text { Civil } \\
\text { Society } \\
\text { Total } \\
\text { Index } \\
\text { (ICSTIN) } \\
\end{array}$ & $\begin{array}{l}\text { Political } \\
\text { Efficacy } \\
\text { Index } \\
\text { (POLEF) }\end{array}$ & $\begin{array}{c}\text { Political } \\
\text { Knowledge } \\
\text { Index } \\
\text { (PKIND) }\end{array}$ & $\begin{array}{c}\text { Interpersonal } \\
\text { Trust Index } \\
\text { (IPTRUST) }\end{array}$ & $\begin{array}{c}\text { Openness of } \\
\text { Political } \\
\text { Participation } \\
\text { Index } \\
(O P I N D X)\end{array}$ & $\begin{array}{c}\text { Acceptance } \\
\text { of } \\
\text { Alternative } \\
\text { Political } \\
\text { Expressions } \\
\text { (APEIND) }\end{array}$ & $\begin{array}{c}\text { Confidence in } \\
\text { Governmental } \\
\text { Institutions } \\
\text { (CIGIND) }\end{array}$ & $\begin{array}{c}\text { Belief That } \\
\text { Government } \\
\text { Actions are } \\
\text { Correct } \\
\text { Index } \\
\text { (BGAIND) }\end{array}$ \\
\hline $\begin{array}{l}\text { Religiosity } \\
\text { (RELIGIOSITY) }\end{array}$ & -.018 & .048 & .026 & .050 & .030 & -.028 & $.122 *$ & -.058 & .040 & $.121^{* *}$ & .062 \\
\hline $\begin{array}{l}\text { Gender } \\
\text { (DIGEN) }\end{array}$ & $.222 * * *$ & .067 & -.041 & .036 & .001 & $.238 * * *$ & .056 & $.210 * * *$ & -.048 & -.031 & $.129 * *$ \\
\hline $\begin{array}{l}\text { Education } \\
\text { (DIEDU) }\end{array}$ & $.268 * * *$ & $.205 * * *$ & $.266^{* * * *}$ & $.265 * * *$ & -.075 & $.213^{* * *}$ & .067 & $.176^{* * *}$ & -.104 & -.081 & .019 \\
\hline Age (DIAGE1) & $.111^{*}$ & $.234 * * *$ & $.204^{* * *}$ & $.258 * * *$ & -.032 & .008 & .037 & .015 & .047 & $-.108 *$ & $-.139 * *$ \\
\hline $\begin{array}{l}\text { Monthly Family } \\
\text { Income } \\
\text { (DINNF) }\end{array}$ & -.040 & .021 & .029 & .023 & -.039 & .063 & -.003 & .071 & -.030 & -.048 & -.055 \\
\hline $\begin{array}{l}\text { Adjusted R } \\
\text { squared }\end{array}$ & .104 & .057 & .059 & .077 & -.006 & .114 & .004 & .090 & .010 & .023 & .027 \\
\hline
\end{tabular}

${ }^{*} \mathrm{p}<.1 ;{ }^{* *} \mathrm{p}<.05 ; * * * \mathrm{p}<.01$ 
Table 5-10: Individual Religiosity Variables and Civil Society

\begin{tabular}{|c|c|c|c|c|c|c|c|c|c|c|c|}
\hline & $\begin{array}{c}\text { Formal } \\
\text { Civil } \\
\text { Society } \\
\text { (FOCIND) }\end{array}$ & $\begin{array}{c}\text { Informal } \\
\text { Civil Society } \\
\text { Participation } \\
\text { (ICSPIN) }\end{array}$ & $\begin{array}{l}\text { Informal } \\
\text { Civil } \\
\text { Society } \\
\text { Support } \\
\text { (ICSSIN) }\end{array}$ & $\begin{array}{l}\text { Informal } \\
\text { Civil } \\
\text { Society } \\
\text { Total } \\
\text { Index } \\
\text { (ICSTIN) } \\
\end{array}$ & $\begin{array}{l}\text { Political } \\
\text { Efficacy } \\
\text { Index } \\
\text { (POLEF) }\end{array}$ & $\begin{array}{c}\text { Political } \\
\text { Knowledge } \\
\text { Index } \\
(P K I N D)\end{array}$ & $\begin{array}{c}\text { Interpersonal } \\
\text { Trust Index } \\
\text { (IPTRUST) }\end{array}$ & $\begin{array}{c}\text { Openness of } \\
\text { Political } \\
\text { Participation } \\
\text { Index } \\
(O P I N D X)\end{array}$ & $\begin{array}{c}\text { Acceptance } \\
\text { of } \\
\text { Alternative } \\
\text { Political } \\
\text { Expressions } \\
\text { (APEIND) }\end{array}$ & $\begin{array}{c}\text { Confidence in } \\
\text { Governmental } \\
\text { Institutions } \\
\text { (CIGIND) }\end{array}$ & $\begin{array}{c}\text { Belief That } \\
\text { Government } \\
\text { Actions are } \\
\text { Correct } \\
\text { Index } \\
\text { (BGAIND) }\end{array}$ \\
\hline $\begin{array}{l}\text { Level of } \\
\text { Religious } \\
\text { Belief } \\
\text { (RBLRB) }\end{array}$ & $-.100 *$ & $-.097 *$ & -.075 & $-.100 *$ & .029 & $.088 *$ & -.048 & .055 & .087 & .078 & .024 \\
\hline $\begin{array}{l}\text { Level of } \\
\text { Religious } \\
\text { Value } \\
\text { (RBLRV) }\end{array}$ & .025 & .067 & .038 & .075 & .005 & -.018 & .077 & -.034 & .024 & .022 & .025 \\
\hline $\begin{array}{l}\text { Level of } \\
\text { Religious } \\
\text { Participation } \\
\text { (RBLRP) }\end{array}$ & .017 & $.101^{*}$ & .036 & $.086^{*}$ & .045 & $-.114 * *$ & $.134 * *$ & $-.138 * * *$ & -.008 & $.108 * *$ & .049 \\
\hline $\begin{array}{l}\text { Gender } \\
\text { (DIGEN) }\end{array}$ & $.223 * * *$ & .077 & -.039 & .043 & .007 & $.223 * * *$ & .069 & $.193 * * *$ & -.051 & -.018 & $.134 * *$ \\
\hline $\begin{array}{l}\text { Education } \\
\text { (DIEDU) }\end{array}$ & $.262 * * *$ & $.197 * * *$ & $.259 * * *$ & $.258 * * *$ & -.074 & $.223 * * *$ & .059 & $.184 * * *$ & -.095 & -.082 & .018 \\
\hline $\begin{array}{l}\text { Age } \\
\text { (DIAGE1) }\end{array}$ & $.118 * *$ & $.240 * * *$ & $.209 * * *$ & $.265^{* * *}$ & -.035 & .005 & .039 & .013 & .041 & $-.116 * *$ & $-.142 * *$ \\
\hline $\begin{array}{l}\text { Monthly } \\
\text { Family } \\
\text { Income } \\
\text { (DINNF) }\end{array}$ & -.039 & .024 & .028 & .025 & -.038 & .061 & -.003 & .068 & -.029 & -.049 & -.055 \\
\hline $\begin{array}{l}\text { Adjusted R } \\
\text { squared }\end{array}$ & .110 & .071 & .061 & .090 & -.007 & .127 & .012 & .104 & .014 & .028 & .024 \\
\hline
\end{tabular}

${ }^{*} \mathrm{p}<.1 ; * * \mathrm{p}<.05 ; * * * \mathrm{p}<.01$ 
The level of religious participation (RBLRP) also has positive significant relationships with the effects of civil society. Greater participation in religion has a positive significant relationship with interpersonal trust (IPTRUST). The greater the religious participation among respondents, the more likely they are going to trust other individuals. This finding is likely the result of positive reciprocal associational activity with other participants in their religious organizations. The positive significant relationship between religious participation (RBLRP) and interpersonal trust (IPTRUST) may also translate into a trust in people in general, resulting in a trust of people in government. This relationship is demonstrated by the significant positive relationship found between the level of religious participation (RBLRP) and the confidence in governmental institutions (CIGIND).

A second possible explanation may also be that people participating in religion develop a “parochial” or "subject” mindset, as demonstrated by Almond and Verba (1963). A “parochial” is an individual who does not interact with the state and whose world view does not extend beyond the direct geographical region. A “subject” is one who has knowledge about politics but does not choose to participate in the state beyond voting. These concepts are demonstrated by the significant negative relationships between the level of religious participation (RBLRP) and the respondent's level of political knowledge (PKIND) and openness of political participation (OPINDX). The greater respondents participate in religion (RBLRP), the less likely respondents are to know the president of Nicaragua, the president of the United States, or the mayor of the respondent's city or town (PKIND). The relationship suggests that the more time 
respondents invest in religious participation, the less time dedicated to understanding or learning about politics.

A significant negative relationship also exists between the level of religious participation (RBLRP) and openness of political participation (OPINDX). This relationship suggests that the more respondents participate in religion (RBLRP), the less open they are to extend participation rights in the political system to those with alternative views (OPINDX). This demonstrates less of a willingness among active religious respondents to accept alternative viewpoints and allow those with alternative views to participate.

Religious respondents may not have fully institutionalized the democratic concept of freedom of expression, which, according to Dahl (1971), is both necessary and sufficient for the maintenance of democracy within a state. The potential for democratic decay lies in respondents’ desire for stability and order over the freedom of expression. Again this may be a product specific to societies affected by a political history characterized by civil war and instability. Finally, there are no significant relationships between the level of religious value (RBLRV) and formal civil society (FOCIND), informal civil society (ICSTIN), or any of the effects of civil society.

\section{$\underline{\text { Role of Religion in Civil Society (RBCRS) }}$}

The role of religion in society (RBCRS) examines the respondents' attitude toward the breadth of issues appropriate for religious organizations to address when entering into the public sphere or an expression of the issues appropriate for Church action. Provided on Table 5-11 are multiple regression beta coefficients showing the 
relationship between the role respondents want religion to play in society and the dependent civil society variables.

Positive significant relationships exist between the role of religion in society (RBCRS) and informal civil society (ICSTIN), political efficacy (POLEF), and openness of political participation (OPINDX). The broader the role for religious institutions (RBCRS), the greater the likelihood that respondents will participate and support informal civil society (ICSTIN). This relationship indicates that participation on and support for informal civil society are being developed through associational activities inside religious organizations. The role of the religious organization becomes the role of individuals. The broader the role for religion in society, the broader the respondents' responsibility is to society.

Another intriguing finding is the positive significant relationship between the role of religion in society (RBCRS) and the effects of civil society, measured partly by political efficacy (POLEF) and openness of political participation (OPINDX). If the respondent believes religious organizations have a major role in society, then the respondent also exhibits high political efficacy. In other words, the greater the role for religious organizations in society, the greater the impact respondents believe they have on the political system. Not only are respondents more confident about their effect on the political system, they are also more secure and likely to extend political participation to those people with alternative view points (OPINDX). 
Table 5-11: Role of Religious Institutions in Society (TOTAL) and Civil Society

\begin{tabular}{|c|c|c|c|c|c|c|c|c|c|c|c|}
\hline & $\begin{array}{c}\text { Formal } \\
\text { Civil } \\
\text { Society } \\
\text { (FOCIND) }\end{array}$ & $\begin{array}{c}\text { Informal } \\
\text { Civil } \\
\text { Society } \\
\text { Participatio } \\
n \\
\text { (ICSPIN) }\end{array}$ & $\begin{array}{l}\text { Informal } \\
\text { Civil } \\
\text { Society } \\
\text { Support } \\
\text { (ICSSIN) }\end{array}$ & $\begin{array}{c}\text { Informal } \\
\text { Civil } \\
\text { Society } \\
\text { Total } \\
\text { Index } \\
\text { (ICSTIN) }\end{array}$ & $\begin{array}{c}\text { Political } \\
\text { Efficacy } \\
\text { Index } \\
(\text { POLEF } \\
\text { ) }\end{array}$ & $\begin{array}{c}\text { Political } \\
\text { Knowledge } \\
\text { Index } \\
\text { (PKIND) }\end{array}$ & $\begin{array}{c}\text { Interpersona } \\
\text { l Trust Index } \\
\text { (IPTRUST) }\end{array}$ & $\begin{array}{c}\text { Openness of } \\
\text { Political } \\
\text { Participatio } \\
n \text { Index } \\
(O P I N D X)\end{array}$ & $\begin{array}{c}\text { Acceptance } \\
\text { of } \\
\text { Alternative } \\
\text { Political } \\
\text { Expression } \\
\text { S } \\
\text { (APEIND) }\end{array}$ & $\begin{array}{c}\text { Confidence in } \\
\text { Governmenta } \\
\text { l Institutions } \\
\text { (CIGIND) }\end{array}$ & $\begin{array}{c}\text { Belief That } \\
\text { Government } \\
\text { Actions are } \\
\text { Correct } \\
\text { Index } \\
\text { (BGAIND) }\end{array}$ \\
\hline $\begin{array}{l}\text { Role of } \\
\text { Religion in } \\
\text { Society } \\
\text { (RCBRST) }\end{array}$ & .027 & $.104^{*}$ & $.182 * * *$ & $.253^{* * *}$ & $.133^{* *}$ & .022 & .083 & $.108^{* *}$ & .083 & .011 & .022 \\
\hline $\begin{array}{l}\text { Gender } \\
\text { (DIGEN) }\end{array}$ & $.222 * * *$ & .063 & -.048 & .029 & -.004 & $.238 * * *$ & .050 & $.208 * * *$ & -.051 & -.034 & $.127^{* *}$ \\
\hline $\begin{array}{l}\text { Education } \\
\text { (DIEDU) }\end{array}$ & $.270 * * *$ & $.197 * * *$ & $.260 * * *$ & $.257 * * *$ & -.080 & $.216 * * *$ & .051 & $.182 * * *$ & $-.110 *$ & -.096 & .011 \\
\hline $\begin{array}{l}\text { Age } \\
\text { (DIAGE1) }\end{array}$ & $.106^{*}$ & $.213^{* * *}$ & $.170 * * *$ & $.229 * * *$ & -.057 & .005 & .020 & -.004 & .031 & $-.112^{*}$ & $-.145^{* *}$ \\
\hline $\begin{array}{l}\text { Monthly } \\
\text { Family } \\
\text { Income } \\
\text { (DINNF) }\end{array}$ & -.038 & .014 & .024 & .015 & -.044 & .066 & -.019 & .077 & -.036 & -.063 & -.063 \\
\hline $\begin{array}{l}\text { Adjusted } \\
\text { R squared }\end{array}$ & .104 & .065 & .090 & .097 & .010 & .113 & -.004 & .097 & .015 & .008 & .023 \\
\hline
\end{tabular}




\section{View of Religious Success in Society (RBCPAI)}

A final concept in discerning the effects of religion on civil society is to identify any possible relationships between attitudes towards the success of religious organizations when fulfilling their mission and the dependent civil society variables. Is there any relationship between perceived success of religious institutions and other social and political institutions? Table 5-12 shows the multiple regression beta coefficients using the view of religious success in society (RBCPAI) as an explanatory variable for the dependent civil society variables. There are no significant relationships between the view of religious success in society (RBCPAI) and participation in formal civil society (FOCIND) and informal civil society support and participation (ICSTIN). However, a number of significant relationships are found with the effects of civil society.

Examination of Table 5-12 shows positive significant relationships between the perceived success of religious institutions in society (RBCPAI) and the respondent's political efficacy (POLEF), level of interpersonal trust (IPTRUST), confidence in governmental institutions (CIGIND), and belief that the actions of government are correct (BGAIND). If respondents view religious institutions as effective, they also view their participation in the political system as effective. Again, an extension of attitudes toward religious institutions affects attitudes toward governmental institutions. Interpersonal trust (IPTRUST) is also significantly related to the view of religious success in society (RBCPAI). If a respondent views religious institutions as successful in society, then they may view those working within the institutions as trustworthy. This trust may also be extended to other types of institutions. 
Table 5-12: View of Religious Success (RBCPAI) and Civil Society

\begin{tabular}{|c|c|c|c|c|c|c|c|c|c|c|c|}
\hline & $\begin{array}{c}\text { Formal } \\
\text { Civil } \\
\text { Society } \\
\text { (FOCIND) }\end{array}$ & $\begin{array}{c}\text { Informal } \\
\text { Civil Society } \\
\text { Participation } \\
\text { (ICSPIN) }\end{array}$ & $\begin{array}{l}\text { Informal } \\
\text { Civil } \\
\text { Society } \\
\text { Support } \\
\text { (ICSSIN) }\end{array}$ & $\begin{array}{c}\text { Informal } \\
\text { Civil } \\
\text { Society } \\
\text { Total } \\
\text { Index } \\
\text { (ICSTIN) }\end{array}$ & $\begin{array}{l}\text { Political } \\
\text { Efficacy } \\
\text { Index } \\
(P O L E F)\end{array}$ & $\begin{array}{c}\text { Political } \\
\text { Knowledge } \\
\text { Index } \\
(P K I N D)\end{array}$ & $\begin{array}{c}\text { Interpersonal } \\
\text { Trust Index } \\
\text { (IPTRUST) }\end{array}$ & $\begin{array}{c}\text { Openness of } \\
\text { Political } \\
\text { Participation } \\
\text { Index } \\
(O P I N D X)\end{array}$ & $\begin{array}{c}\text { Acceptance } \\
\text { of } \\
\text { Alternative } \\
\text { Political } \\
\text { Expressions } \\
\text { (APEIND) }\end{array}$ & $\begin{array}{c}\text { Confidence in } \\
\text { Governmental } \\
\text { Institutions } \\
\text { (CIGIND) }\end{array}$ & $\begin{array}{c}\text { Belief That } \\
\text { Government } \\
\text { Actions are } \\
\text { Correct } \\
\text { Index } \\
\text { (BGAIND) }\end{array}$ \\
\hline $\begin{array}{l}\text { Religious } \\
\text { Success in } \\
\text { Society } \\
\text { (RBCPAI) }\end{array}$ & -.060 & .008 & .015 & .011 & $.200 * * *$ & -.067 & $.136^{* * *}$ & -.083 & .065 & $.278^{* * *}$ & $.211^{* * *}$ \\
\hline $\begin{array}{l}\text { Gender } \\
\text { (DIGEN) }\end{array}$ & $.224 * * *$ & .066 & -.042 & .034 & -.004 & $.241^{* * *}$ & .050 & $.213^{* * *}$ & -.050 & -.040 & $.123^{* *}$ \\
\hline $\begin{array}{l}\text { Education } \\
\text { (DIEDU) }\end{array}$ & $.251 * * *$ & $.201 * * *$ & $.267 * * *$ & $.263 * * *$ & -.016 & $.195^{* * *}$ & .095 & $.158^{* * *}$ & -.088 & -.010 & .077 \\
\hline $\begin{array}{l}\text { Age } \\
\text { (DIAGE1) }\end{array}$ & $.105 *$ & $.233 * * *$ & $.205^{* * *}$ & $.259 * * *$ & -.013 & .002 & .049 & .008 & -.052 & -.082 & $-.119 * *$ \\
\hline $\begin{array}{l}\text { Monthly } \\
\text { Family } \\
\text { Income } \\
\text { (DINNF) }\end{array}$ & .-041 & .016 & .027 & .018 & -.033 & .063 & -.011 & .074 & -.032 & -.050 & -.052 \\
\hline $\begin{array}{l}\text { Adjusted } \\
\text { R squared }\end{array}$ & .110 & .057 & .061 & .078 & .033 & .119 & .010 & .095 & .015 & .083 & .066 \\
\hline
\end{tabular}


The relationship is further documented by the significant positive relationships between view of religious success (RBCPAI) and attitudes toward political institutions, measured through the confidence in governmental institutions (CIGIND) and belief that government actions are correct (BGAIND). If people believe that religious institutions are successful in society, they also tend to view political institutions as worthy of confidence and believe their actions to be correct. A trust in one set of political and social institutions may provide for a broader trust of institutions in general.

\section{Discussion}

The regression models presented above provide interesting insight between religion and civil society. First, it does not appear that any of the particular religious denominations studied here are significant producers of Civil Society I or those forms of civil society that help maintain democratic institutions. On the other hand, there is also no evidence that participation in any of the denominations under review is truly a hindrance to democracy. The relationship between religious institutions and the creation of a civil society capable of maintaining democratic institutions has very little to do with denomination and is more closely related to religiosity. The concepts of religiosity producing significant relationships are to the role of religious institutions in society (RBCPAI) as well as their perceived success (RCBRST).

Respondents believing that religious institutions should play a larger role in society are more likely to participate and support informal civil society, display greater political efficacy, and support an open political environment. This relationship suggests that if religious institutions are to play a large role in society, then so, too, must the adherents. Adherents believing this are then more likely to involve themselves in finding 
solutions to society's problems. In other words, associational activity occurring within religious institutions influences the adherents to live out their religion in society and thus work to find solutions to social, economic, and political problems.

A second interesting finding worth discussion is the relationship between the respondents' perception of success among religious institutions and their view of all institutions. If respondents view religious institutions as successful they are more likely to display high levels of political efficacy and interpersonal trust. Furthermore, success or confidence in religious institutions translates into confidence in governmental institutions and belief that the actions of government are correct. Essentially, perceived success of one set of institutions may translate into perceived success of social, economic, and political institutions in general.

From these findings it appears that religious institutions are playing a large role in Nicaraguan society and are successful at doing it. The associational activities found in religious institutions may be directly adding to civil society by producing positive attitudes towards other social, economic, and political institutions. 


\section{Chapter Six}

\section{Introduction: The Case of El Salvador}

Chapter Six explores the effects of religion on civil society through a comparative case study of El Salvador. Analysis in this chapter is conducted to gain an appreciation of whether the religious trends taking place are specific to Nicaragua or part of a larger movement within Central America. Data on El Salvador comes from the 1995-1996 wave of the World Values Survey (WVS) managed by Inglehart (2004), at the Institute for Social Research at The University of Michigan. The survey of El Salvador, though not published until 2004, was conducted using the third wave 1995-1996 World Value Survey Codebook. $^{37}$

Examination of the 1995-1996 World Value Survey Codebook finds comparable measures to the independent and dependent variables constructed for Nicaragua. However, not all questions were asked in every country represented in the 1995-1996 wave of the WVS. As a result the author was unable to reconstruct measures for Informal Civil Society (WVS: V59), Role of Religion in Society (not available in WVS), or Success of Religion in Society (WVS: V187-190). The measure for the Level of Religious Participation the author uses for Nicaragua are in the WVS Codebook (V197199), but not asked in El Salvador. Level of Religious Participation was reconstructed using the frequency of church attendance (WVS: V181). Finally, only one question measuring the Level of Religious Value (WVS: V191) was asked in El Salvador.

\footnotetext{
${ }^{37}$ The 1995-1996 World Values Survey Codebook was down loaded from http://www.worldvaluessurvey.org/statistics/index.html
} 
As a result of discrepancies in available variables, as well as differences in question wording and coding, the author was unable to reconstruct many of the index variables. The analysis provided in this chapter is descriptive and preliminary in nature.

\section{Background}

Geographically, El Salvador is the smallest and most densely populated state in Central America, with a population of 6,587,541 on 20,720 square kilometers (CIA World Factbook 2004). Comparatively, Nicaragua is the largest and least densely populated state in Central America, with a population of 5,359,759 on 120,254 square kilometers of land (CIA World Factbook 2004). Irrespective of geographical diversity, the majority of the population in both states live in urban areas due to considerable rural to urban transition prompted by war and social dislocation (Williams 1998, 183-186; Williams and Peterson 1996, 873-374).

Like Nicaragua, El Salvador also experienced a prolonged civil war between Salvadoran elites protecting their economic power through the Alianza Republicana Nacional (ARENA) and a Marxist-inspired revolutionary movement led by the Frente Farabundo Martí de Liberación Nacional (FMLN). Fought first in civil society, the attempts by elites to subdue lower classes unleashed opposition civil society actors like the Progressive Church, as well as teachers and workers unions (Foley 1996, p. 67-68). Characterized by death squads and indiscriminant killing, El Salvador's civil war was one of the deadliest in the region, lasting 12 years with tens of thousands "disappeared, ” 75,000 Salvadorans killed, and 500,000 refugees created (Chavez 2004; Foley 1996). Similar to the civil war in Nicaragua, religious actors, namely the "Progressive" Catholic Church, played a major role in the struggle. Inspiration for the Progressive Church in El 
Salvador came from Archbishop Oscar Romero, who was assassinated for his criticisms of government and support for popular organizations (Williams and Peterson 1996, p. 874-877).

Socioeconomic status is one difference between otherwise similar states. According to the United Nations Development Office (UNDP), Nicaragua ranks 118 on the Human Development Index, with a Gross Domestic Produce per capita income of \$2,400 (ppp). El Salvador ranks 103 on the Human Development Index, with a Gross Domestic Product per capita twice that of Nicaragua at $\$ 4890$ (ppp). ${ }^{38}$ The enhanced economic development of El Salvador should provide an advantage in democratization efforts and the development of civil society. ${ }^{39}$ Przeworski and Limongi (1997, p. 155157) claim economic development is vital to the success of democratic institutions, as per capita income correctly classifies democracies in 77 percent of 4126 observations.

By and large, Nicaragua and El Salvador are comparable due to their similar political histories. Both states experienced Marxist inspired civil wars similarly influenced by fragmentation between the Traditional and Progressive Catholic Church (Williams 1998, p. 184-186). A second similarity in the transformation of religious institutions includes a steady growth in Evangelical Protestant and Pentecostal populations. According to Stoll (1990, p. 337), Evangelicals and Pentecostals in El Salvador grew from 2.45 percent of the population in 1960 to 12.78 percent in 1985.

\footnotetext{
${ }^{38}$ These statistics were downloaded from the United Nations Human Development Office at http://hdr.undp.org/statistics/data/indic/indic_124_1_1.html. The Human Development Index (HDI) ranks were downloaded from http://hdr.undp.org/reports/global/2004/pdf/presskit/HDR04_PKE_HDI.pdf. A states human development according to Gross Domestic Product per capita, Life Expectancy at Birth, and Literacy Rate. GDP per capita measure are 2002 estimates

${ }^{39}$ Accurding to the UNDP Human Development Report El Salvador has the fourth highest GDP per capita among the seven Central American states. For a complete list see http://www.undp.org/hdr2003/indicator/indic_4_1_1.html
} 
Nicaragua's religious transformation is less dramatic, going from 2.26 percent of the population in 1960 to 6.32 percent in 1985 (Stoll 1990, p. 337)

\section{Religious Denomination in El Salvador (WVS: V179)}

More recent estimates for religious demographics in El Salvador vary greatly depending on the source. The CIA World Fact Book (2004) estimates Catholics to make up 83 percent of the overall population. The multi-denominational Christian legal organization Advocates International approximates the Catholic population to be a mere 48 percent of the population, with an Evangelical population of 30 percent (2004).

According to the U.S. Department of State, a 1995 survey conducted by the Central American University Public Opinion Institute (IUDOP), found a Catholic population of

56.7 percent. $^{40}$ Table 6-1 provides religious populations found by the 1995-1996 wave of the WVS.

Table 6-1: Religious Denominations in El Salvador (WVS: V179)

\begin{tabular}{l|cc}
\hline & Frequency & Percentages \\
\hline Roman Catholic & 406 & 32.4 \\
Catholic: “Does not follow rules” & 332 & 26.5 \\
Evangelical & 288 & 23 \\
Buddhist & 28 & 2.2 \\
Not A Member & 200 & 15.9 \\
Total & 1254 & 100 \\
\hline
\end{tabular}

Table 6-1 shows that in El Salvador, 58.9 percent of the sample population choose Catholicism as their primary religious provider. Catholicism is further divided between the 32.4 percent of the sample population claiming to be Traditional Roman Catholic and

\footnotetext{
${ }^{40}$ Information from the U.S. Department of State was downloaded from http://www.state.gov/g/drl/rls/irf/2001/5639.htm. Information from Advocates International was downloaded from www.advocatesinternational.org. Advocates International statistics come from their website last modified on October 14, 2004. Information from the C.I.A. World Factbook was downloaded from http://www.cia.gov/cia/publications/factbook/geos/es.html.
} 
the 26.5 percent claiming to be a Catholic which "Does not follow rules." Catholics who do not follow the rules include Progressive, Charismatic, and non-practicing Catholics. El Salvador also has a substantial Evangelical population at 23 percent. Unfortunately, the WVS does not provide a further breakdown of Evangelicals into their specific denominations, making it difficult to make definite statements about denominational effects.

Compared with Nicaragua, the Evangelical movement in El Salvador shows a similar pattern. Salvadoran Evangelicals account for 23 percent of the population, which is slightly less of a proportion of the population than the 26.1 percent in Nicaragua. The two states differ greatly in regards to Traditional Catholic adherents, with 67.4 percent in Nicaragua doubling the 32.4 percent in El Salvador. Yet in El Salvador, 26.5 percent of the sample population does claim to be Catholic outside the Traditional Roman Catholic Church. Discrepancies between Catholic populations in Nicaragua and El Salvador may be explained by differences in interview techniques used for discerning among the variations of Catholicism.

El Salvador's political and economic development may also explain the high percentage of the population choosing alternative forms of Catholicism and Evangelical denominations. Acccording to Williams “...

The dramatic growth of Pentecostalism in El Salvador after the mid 1970s is undoubtedly related to the deepening political and economic crisis that plunged the country into an unending cycle of violence and despair...The social dislocation resulting from the war and economic crisis created increasingly precarious condition for the majority of Salvadorans (1998, p. 183)

Williams further states that the large number of dislocated Salvadorans and the over 1.2 million making the urban to rural transition left many citizens searching 
for “...solutions to their spiritual and physical insecurities” (Williams 1998, p.

183-185).

A second interesting religious phenomenon differentiating Nicaragua and El Salvador are respondents claiming to be non-members of Christian denominations. In Nicaragua 3.5 percent of the sample population stated being non-Christian or other, with .2 percent being Muslim. The WVS (2004) finds El Salvador's population claiming to be non-Christian or other at 18.1 percent, with 2.2 percent espousing Buddhism. Overall, 15.9 percent of the Salvadoran population denies membership in any religious organization. This is astounding given the critical role of religion in traditional societies.

\section{Religiosity in El Salvador}

\section{$\underline{\text { Level of Religious Participation - V181 }}$}

The level of religious participation in the WVS is measured by the frequency of church attendance. Unfortunately, how often the respondent participates in religion through consultation with God, though on the WVS questionnaire, was not asked in El Salvador. Table 6-2 provides the WVS (2004) estimation for the frequency of church attendance in El Salvador.

Table 6-2: “How often do you attend religious services (WVS: V181)?”El Salvador

\begin{tabular}{l|cc}
\hline & Frequency & Percentages \\
\hline More than once a week & 357 & 28.5 \\
Once a week & 351 & 29.6 \\
Once a month & 134 & 10.7 \\
Only on special holy days & 75 & 6.0 \\
Once a year & 78 & 6.2 \\
Less often & 87 & 6.9 \\
Never & 151 & 12.1 \\
Total (N) & 1253 & 100 \\
\hline
\end{tabular}


Analysis of Table 6-2 finds 58.1 percent of the sample population attends church services once a week or more. Furthermore, 13.7 percent of the population claim to be non-members of religious denomination, but only 12.1 percent claim they never attend religious services. This inconsistency leaves 1.6 percent of the population either inflating church attendance or misrepresenting themselves as non-members. Irrespective of this, the level of religious participation, as measured by Church attendance, shows an actively religious population, demonstrating that religiosity is still high in El Salvador. These findings run counter to the idea of secularization among Salvadoran society triggered by relative economic progress. Active Church participation may be crucial to the development of democratic civil society and social capital as the most common form of associational activity.

Level of Religious Value (V191)

The Level of Religious Value (WVS: V191) is measured by asking Salvadoran respondents to state whether they find strength and comfort in religion. This question was also asked in Nicaragua, yielding similar results. Table 6-8 is shows a comparative analysis of both populations.

Table 6-3: “Do you find strength and comfort from religion (WVS: V191)?”

\begin{tabular}{l|cccc}
\hline & $\underline{\text { El Salvador }}$ & & $\underline{\text { Nicaragua }}$ & \\
& Frequency & Percentages & Frequency & Percentages \\
\hline Yes & 1078 & 88.5 & 525 & 89.7 \\
No & 140 & 11.5 & 60 & 10.3 \\
Total (N) & 1218 & 100 & 585 & 100 \\
\hline
\end{tabular}

The findings are similar, with 89.7 percent of respondents in Nicaragua and 88.5 percent in El Salvador stating they find strength and comfort in their religion. Significant portions of both societies having positive feelings for religion implies that religion 
continues to be a valuable component of both societies. These high rates also suggest that respondents in both societies utilize religious organizations and associational activities as an escape from daily obstacles. Finding strength and comfort from religion implies that, when the faced with obstacles or feelings of despair emerge, the majority of respondents look to religion for relief and security.

Level of Religious Belief - (V183-189)

The level of religious belief (WVS: V183-189) measures the span of religious constructs used by respondents when consulting religion for solutions to life's obstacles. Table 6-2 shows similar religious characteristics between Nicaraguan and Salvadoran respondents.

Table 6-4: Please indicate whether you believe in any of the following ... (WVS: V183-189)

\begin{tabular}{l|cccccc}
\hline & $\begin{array}{c}\text { "Yes” in } \\
\text { Percentages }\end{array}$ & $\begin{array}{c}\text { El Salvador } \\
\text { "No" in } \\
\text { Percentages }\end{array}$ & $N$ & $\begin{array}{c}\text { "Yes” in } \\
\text { Percentages }\end{array}$ & $\begin{array}{c}\text { Nicaraqua } \\
\text { "No" In } \\
\text { Percentages }\end{array}$ & $N$ \\
\hline God (V183) & 99.4 & .6 & 1250 & 99.7 & .3 & 598 \\
Life After Death (V184) & 83.4 & 16.6 & 1190 & 86.5 & 13.5 & 550 \\
A Soul (V185) & 93.6 & 6.4 & 1233 & 95 & 4.9 & 576 \\
The Devil Exists (V186) & 74.4 & 25.6 & 1238 & 76.6 & 23.3 & 579 \\
Hell Exists (V187) & 76.4 & 23.6 & 1236 & 74 & 26 & 572 \\
Heaven Exists (V188) & 86.1 & 13.9 & 1229 & 93.8 & 6.2 & 584 \\
Sin (V189) & 95.1 & 4.9 & 1251 & 98.5 & 1.5 & 601 \\
\hline
\end{tabular}

Note: Belief in Resurrection of the Dead and Reincarnation do not appear in the 1995-1996 World Values Survey Codebook.

An examination of Table 6-4 shows remarkable similarities in the level of religious value between data provided by the WVS for El Salvador and the Nicaraguan data collected for this research. Nearly 100 percent of respondents in both countries believe in God, and both sets of respondents display similar patterns of greater belief in the positive over the negative religious concepts. Both populations find the lowest rates 
of belief in the negative religious constructs of Hell and the Devil. Surprisingly, both also have the third lowest rate of belief in the positive construct of life after death. This relationship can be explained by the fact that life after death can be both a negative and positive construct. The question (WVS: V184) does not specify whether respondents will be spending life after death in heaven or hell.

The diverging beliefs between positive and negative constructs of religion strengthen the assertion that conversion is activated through a desire to escape everyday hardships by way of religious expression and institutions. The otherworldly concept of a soul, providing identity, and heaven, providing paradise, gives hope to individuals. These positive constructs are more easily applied to one's life than negative constructs. The fear brought on by belief in the existence of the devil and hell does not provide hope to the individual, but are undesirable consequences of bad behavior. The purpose of these constructs is to restrict behavior.

\section{State of Formal Civil Society ${ }^{41}$}

This section examines the state of formal civil society participation in El Salvador. Table 6-5 is a breakdown of membership in various civil society organizations. The variables provided below are parallel to those on the Nicaraguan survey instrument. One major difference is the coding of answers. The Nicaraguan survey instrument places the level of participation with formal civil society organizations on a five-point Likert Scale. The 1995-1996 WVS survey instrument codes the level of membership on a threepoint Likert Scale.

\footnotetext{
${ }^{41}$ Formal Civil Society in the World Values Survey (WVS 1995-1996) measured by variables (V 29, 30, 31, 32, 33, 34, 35) Membership or participation in Formal Civil Society in the WVS 1995-1996 Codebook is placed on a three rather than five point Likert-scale.
} 
Table 6-5: Membership in Formal Civil Society Organizations - El Salvador

\begin{tabular}{l|cccc}
\hline & Active Member & $\begin{array}{l}\text { Inactive } \\
\text { Member }\end{array}$ & Not a Member & Total \\
\hline Member of sports or recreation group & 40.4 & 16 & 43.6 & $100 \%$ \\
(WVS: V29) & $(506)$ & $(200)$ & $(546)$ & $(1252)$ \\
Art, Music, or Education group & 9.9 & 3.3 & 86.8 & $100 \%$ \\
(WVS: V30) & $(124)$ & $(41)$ & $(100)$ & $(1254)$ \\
Members of Political Parties & 2.2 & 1.6 & 96.3 & $100 \%$ \\
(WVS: V32) & $(27)$ & $(20)$ & $(1207)$ & $(1254)$ \\
Members of Labor Unions & 1 & 1.2 & 97.8 & $100 \%$ \\
(WVS: V31) & $(13)$ & $(15)$ & $(1226)$ & $(1254)$ \\
Members of Professional Organizations & 4.7 & 1.6 & 93.7 & $100 \%$ \\
(WVS: V34) & $(59)$ & $(20)$ & $(1175)$ & $(1254)$ \\
Member of a Charitable Organization & 9.8 & 1.4 & 88.8 & $100 \%$ \\
(WVS: V33) & $(123)$ & $(17)$ & $(1114)$ & $(1254)$ \\
\hline
\end{tabular}

Note: Scores not in parenthesis are percentages and those in parenthesis are frequencies

Analysis of Table 6- 5 is taken variable by variable below to provide a thorough understanding of formal civil society participation outside of religious institutions in El Salvador. Overall, participation in the formal sectors of civil society is very similar in Nicaragua and El Salvador. Membership in formal organizations also does not appear to be a central concern to the majority of Salvadorans.

Sports, Arts and Education Membership in El Salvador (WVS: V29; V30)

In El Salvador sports and recreation groups (WVS: V29) are among the most popular formal organizations, with 11.7 percent of the sample population claiming “active” membership, which is larger than the 9.9 percent in Nicaragua. ${ }^{42}$ Educational and arts organizations (WVS: V30) also share a similar pattern between the two populations, with 9.9 percent of Salvadorans and 8.3 percent of Nicaraguans claiming membership. Though alike, El Salvador does have a slightly higher percentage of the population participating in these organizations. It appears that in El Salvador these organizations are slightly better organized.

\section{Political Parties (WVS: V32)}

\footnotetext{
42 The World Values Survey (1995-1996) measures membership on a three point scale with the options being “Active Member”; "Inactive Member”; and “Not a Member”
} 
Membership in political parties is stronger in Nicaragua than in El Salvador. Only 3.7 percent of the Salvadoran sample population state "active” or "inactive" membership in political parties, while 12.5 percent of the Nicaraguan population claims some level of membership. Discrepancies in the sample populations may be the result of one major difference in their political histories. While both states endured civil war through Marxist uprisings, the success of the FSLN in Nicaragua influenced party membership, as a strong party is central to Communist movements. Furthermore, El Salvador's civil war was an extremely bloody affair, with indiscriminant violence. For example, Chavez $(2004,31)$ states "El Salvador...is often described as one of the most violent countries in the region”. The political environment throughout the civil war was one where any expression or overt statement of political belief was extremely dangerous and perceived as a threat to one side or the other. The residual effect of previous political violence may generate hesitance among Salvadoran respondents outwardly to commit to one party over another.

El Salvador and Nicaragua also demonstrate similar patterns in self-placement on the Left-Right continuum. Table 6- 6 shows a comparative itemization of respondents' political self-placement on the political spectrum for both sample populations. 
Table 6-6: Political Self-placement on the Left-Right Continuum in El Salvador (WVS: V123) and Nicaragua

\begin{tabular}{l|cccc}
\hline & $\begin{array}{c}\text { El Salvador } \\
\text { Frequency }\end{array}$ & Percentages & $\begin{array}{c}\text { Nicaragua } \\
\text { Frequency }\end{array}$ & Percentages \\
\hline Right -10 & 252 & 25.1 & 87 & 14.5 \\
9 & 32 & 3.2 & 39 & 3.6 \\
8 & 71 & 7.1 & 61 & 10.1 \\
7 & 59 & 5.9 & 41 & 6.8 \\
6 & 161 & 16.0 & 17 & 2.8 \\
5 & 257 & 25.6 & 225 & 37.4 \\
4 & 20 & 2.0 & 11 & 1.8 \\
3 & 17 & 1.7 & 33 & 5.5 \\
2 & 16 & 1.6 & 18 & 3.5 \\
Left - 1 & 119 & 11.9 & 69 & 11.5 \\
Total & 1004 & 100 & 601 & \\
\hline
\end{tabular}

Similar to the political self-placement of Nicaraguans, large segments of the Salvadoran sample population place themselves near the center or do not strongly associate with the left or right. For those respondents associating themselves with the left or right, a greater number of Salvadorans place their political beliefs on the right as opposed to the left. This trend is also occurring in Nicaragua, suggesting a similar political culture born out of a backlash toward leftist parties like the FSLN and FMLN. Support for leftist parties renews the fear of violence and civil war, which remains fresh in the collective memories of the voting age public. However, informal interviewer conversations found many supporters of the FSLN in Nicaragua to be enthusiastic and collectively fear a return to the repressive regimes of men like the Somozas.

\section{Labor Unions (V31)}


Labor unions in El Salvador have also not been institutionalized. Only one percent of the sample population state “active” membership, with 1.2 percent stating “inactive” membership. In contrast, Nicaragua has 3.7 percent espousing "active” membership with an overall 5.3 percent stating membership in some form. The discrepancy between membership in Nicaragua and El Salvador is likely the result of the state imposed Sandinista Confederation of Labor (CST) for urban workers and the Association of Agricultural Workers (ATC) for agrarian workers under the slogan "Only one workers' class, only one trade union” (Belli 1986, p. 79-81). Under the Sandinista regime these institutions could not be considered civil society due to their state affiliation. Today the CST and ATC are considered private civil society organizations regardless of their current association with the FSLN.

Professional Associations (V34)

Membership in professional associations is slightly less common in El Salvador, with 6.3 percent claiming "inactive" membership and 4.7 percent claiming "active" membership. Nicaragua, by contrast, has 8.2 percent of the population espousing membership. Of the Nicaraguan respondents, 7.9 percent stated "active” or "somewhat active” membership. Inflation among Nicaraguan respondents may exist as many of the respondents may have equated professional associations with transportation or artisan collectives. El Salvador has a healthier economy, meaning that a greater number of professional associations may exist.

Charitable Organization (V35)

Memberships in charitable or philanthropic organizations are more popular in El Salvador than Nicaragua. Only 3.2 percent of the respondents claimed membership to 
these organizations in Nicaragua, but a surprising 11.2 percent stated membership in El Salvador. Overall, 9.8 percent of the Salvadoran respondents claim "active” membership. Low membership in charitable organizations among Nicaraguan respondents may be the result of a bias in the sample population. The researcher encountered difficulty accessing upper income respondents, as they were either uninterested in participating or the interviewer was denied access by those working at the residence. Income levels are associated with participation in charitable organizations, and given El Salvador's higher per capita income and better ranking on the Human Development Index, may also explain strong participation rates among Salvadorans in these organizations.

\section{Effects of Civil Society}

Interpersonal Trust (WVS: V27)

The 1995-1996 World Values Survey Codebook (WVS) provides similar questions for interpersonal trust to those supplied on the Nicaragua survey instrument. Unfortunately, these questions were not asked in El Salvador. To gain insight into interpersonal trust, the WVS simply asked the respondent whether most people can be trusted. Trust in other individuals in El Salvador is rather dismal. Only 14.1 percent of the population feels most people can be trusted, while 85.9 percent feel that you must be careful when dealing with others. In Nicaragua interpersonal trust levels are higher, with 27.4 percent of the sample population finding others to be generally trustworthy (IPTPG). However, when asked whether people try to take advantage of others, 78.5 percent of the sample population in Nicaragua "agrees". The results indicate that interpersonal trust levels in El Salvador and Nicaragua are quite low. 
Causes for low interpersonal trust levels among Salvadorans are likely related to the prolonged ten-year civil war. El Salvador is also a very densely populated country, with the majority living in and around San Salvador. Social dislocation and higher population density increases the contact between citizens, especially for those going through the rural to urban transition. Negative interactions with desperate individuals in a new environment may also be exacerbating lower interpersonal trust levels.

\section{Confidence in Governmental Institutions}

Confidence in Governmental Institutions (CIGIND) on the Nicaraguan survey instrument asks respondents to state their level of confidence on a five-point Likert scale. The 1995-1996 WVS Codebook uses a four-point scale. The major difference is the Nicaraguan survey instrument allows respondents to state whether they have "total confidence" in the institution. Other differences include the institutions represented. The Nicaraguan survey instrument provided the respondent with “The President”, and does not include the "Armed Forces". Table 6-6 provides an examination of confidence respondents have in governmental intuitions.

Table 6-17: How much confidence do you have in the following institutions? El Salvador

\begin{tabular}{l|lllll}
\hline & A Great Deal & Quite A Lot & Not Very Much & None At All & Total \\
\hline Armed Forces & 25.6 & 19.7 & 29.5 & 25.2 & 100 \\
(WVS: V136) & $(320)$ & $(246)$ & $(369)$ & $(315)$ & $(1250)$ \\
The Police & 22.6 & 26.4 & 31 & 20 & 100 \\
(WVS: V141) & $(283)$ & $(330)$ & $(387)$ & $(250)$ & $(1250)$ \\
Parliament & 10.9 & 20.1 & 32.7 & 36.3 & 100 \\
(WVS: V144) & $(134)$ & $(247)$ & $(401)$ & $(446)$ & $(1228)$ \\
The Government & 17.5 & 23 & 30.3 & 29.2 & 100 \\
(WVS: V142) & $(218)$ & $(287)$ & $(377)$ & $(364)$ & $(1246)$ \\
Legal System & 18.6 & 22.3 & 33.4 & 25.7 & 100 \\
(WVS: V137) & $(230)$ & $(275)$ & $(412)$ & $(318)$ & $(1235)$ \\
\hline
\end{tabular}

Note: In parentheses are the frequencies from the WVS survey. Not in parentheses are the valid percentages. 
Examination of Table 6-7 shows that 49 percent of the Salvadoran respondents have "a great deal" or "quite a lot" of confidence in the police. In Nicaragua, 49 percent of the sample population stated having "somewhat" to "total" confidence in the police. Therefore, in both states the police are one of the most widely regarded political institutions. Relatively high confidence levels in the police for each society shows that the government organization involved in most interactions with citizens is doing a good job garnering confidence in the government. These high confidence rates may also be linked to a desire on the part of the citizens for stability and order following decades of civil unrest.

Confidence in legislative bodies is also similar across the two states. In El Salvador, 69 percent of the sample population have "little" or "no" confidence in the unicameral Asamblea Legislativa. In Nicaragua, 66.2 percent of the sample population state having "little" or "no" confidence in the unicameral Asamblea Nacional. Low confidence levels in legislative bodies are negative for the maintenance of democratic institutions. Neither Salvadorans nor Nicaraguans view legislative bodies as representative of society in general and are constantly disappointed by the inability of politicians and legislators to fulfill their campaign promises. This constant disappointment may have created a belief that legislative bodies are not effective political institutions. Furthermore, in both societies civil unrest was born out of the concept of class warfare, meaning the majority of poor and working class respondents may view their respective legislative bodies as elite institutions.

The legal systems of Nicaragua and El Salvador also share low rates of confidence. In El Salvador, 59.1 percent of the sample population state having "not very 
much" to "no" confidence in the legal system. Comparably, 58.4 percent of the Nicaraguan sample population state having "little" to "no" confidence in the legal system. The Nicaraguan and Salvadoran lack of confidence in their respective legal systems is part of an overall distrust of domestic political institutions. The legal systems of both states may also be seen as elite institutions.

The lack of confidence in the majority of domestic political institutions is unfavorable for the maintenance of democracy in the region. On the positive side, those institutions where the greatest interaction between governmental officials and the citizens take place, the police, confidence seem to be developing. However, confidence in the police may be the result of a desire for stability and order. As one moves up the ladder of political institutions, further and further away from the average citizen, confidence begins to wane. This lack of confidence has been born out of civil uprisings inspired by economic class divergence, where high profile government institutions have traditionally been seen as elite institutions.

Acceptance of Alternative Political Expressions (V: 118; 119; 120; 121; 122)

Acceptance of alternative political expressions in the WVS differs from the research conducted in Nicaragua in regards to responses. The survey in Nicaragua asks respondents to state their level of agreement with alternative political activities as a form of political expression. The WVS in El Salvador asks respondents their experiences with alternative forms of political expressions. As a result responses vary as respondents may accept alternative forms of expression even though they have not participated in such activities. 
Table 6-8: Have you ever participated in the following form of political expression? El Salvador

\begin{tabular}{l|cccc}
\hline & Have Done & Might Do & Never Do & Total \\
\hline Signing a Petition & 19.3 & 41.1 & 39.6 & 100 \\
(WVS: V118) & $(222)$ & $(473)$ & $(456)$ & $(1151)$ \\
Attending Lawful Demonstration & 5 & 14.2 & 80.7 & 100 \\
(WVS: V120) & $(59)$ & $(167)$ & $(946)$ & $(1172)$ \\
Joining Unofficial Strikes & 1.5 & 6.2 & 92.3 & 100 \\
(WVS: V121) & $(18)$ & $(73)$ & 1090 & $(1181)$ \\
Occupying Buildings and Factories & .7 & 5 & 94.4 & 100 \\
(WVS: 122) & $(8)$ & $(59)$ & 1120 & 1187 \\
\hline
\end{tabular}

Note: In parentheses are the frequencies from the WVS survey. Not in parentheses are the valid percentages. "Joining Boycotts", though in the WVS codebook was not asked in El Salvador.

Irrespective of measurement differences, acceptance of alternative forms of political expression show similar patterns in Nicaragua and El Salvador. In El Salvador a combined 60.4 percent of the sample population "have" or "might" consider signing a petition as an acceptable form of political expression. In Nicaragua 73.4 percent of the sample population "agree" or "strongly agree" that signing a petition is an acceptable form of political expression. For the maintenance of democratic institutions, high rates of acceptance for signing a petition demonstrates health as freedom of expression has been institutionalized.

In El Salvador, 19.2 percent of the sample population "have” or "might” attend legal demonstrations. In Nicaragua, 83.4 percent of the sample population "strongly agree” or "agree” with the right of people to attend legal demonstrations. The discrepancy between these two populations is most likely the result of coding techniques. In El Salvador respondents might not attend legal demonstrations, but it does not mean these respondents disagree with the right of individuals to attend legal demonstrations. In both states signing petitions and attending legal demonstrations appear to be acceptable forms of political expression. These two forms tend to be the most widely accepted because they are the least likely to result in violence. It appears that in both Nicaragua 
and El Salvador the freedom of expression has been institutionalized as long as that form does not engender a potential for violence. Essentially, the acceptance of freedom of expression is positive for the maintenance of democratic political institutions.

In El Salvador, only 7.8 percent of the population "have” or "might” join unofficial strikes and even less, 5.7 percent of the sample population "have" or "might" occupy buildings or factories. Similar patterns emerge in Nicaragua, as 74.5 percent of the respondents "disagree" or "strongly disagree” with joining boycotts. Furthermore, 83.5 percent of the Nicaraguan sample population "disagrees" or "strongly disagrees" with the occupation of buildings or factories. The sharp decline in support for these two alternative political expressions is likely caused by the inherent potential in each form of expression to escalate into violence. Both Nicaraguans and Salvadorans demonstrate little tolerance for political violence, which is not surprising given their violent political histories. On the whole, it appears that in both societies there exists a respect for the freedom of expression. The Nicaraguan field research is testimony to this by the eagerness of respondents who enthusiastically expressed themselves in the course of interviews. However, this democratic freedom does have its limits. Essentially, alternative forms of political expression with a propensity for violence are not tolerated.

\section{Discussion}

Chapter Six strives to provide an understanding as to whether the religious and political transformations taking place are unique to Nicaragua or part of a larger trend effecting Central America as a whole. Judging from the similarities between Nicaragua and El Salvador, it appears that political and religious transformations are occurring throughout the Central America. In both societies participation in formal civil society 
organizations outside religious institutions is somewhat rare. Both societies openly accept the freedom of expression, but place strict limitations based on the expressions propensity to result in violence. Nicaragua and El Salvador both suffer low confidence in governmental institutions, which is most likely the result of socialized class conflict before and during Marxist uprisings. The majority of Nicaraguans and Salvadorans see the national political institutions as elite institutions incapable or unwilling to address the economic, social, and political challenges facing the majority of Nicaraguans and Salvadorans.

Greater economic and social dislocation occurring in El Salvador has produced a more intense change in the domestic religious structure. Greater dislocation shows a more dramatic fragmentation in the Catholic Church, with the Catholic population relatively equally dispersed between "Traditional" and those who "Do not follow the rules” (WVS:V179, 2004). Trends away from Catholicism are just as staggering, with large portions of society shifting toward Evangelical Protestantism, largely through Pentecostalism. Moreover, secularization appears to be occurring with democratization and economic changes in El Salvador, as a large portion of the sample population claim to be non-members of Christian denominations.

The number of respondents claiming no religious affiliation may also be a residual effect of the violent civil war. During the civil war, association with the Progressive Church may have brought forth a wrath from the right in the form of death squads. Conversely, affiliation with the Traditional Salvadoran Catholic Church may have resulted in oppression by Left or FMLN sympathizers. The few groups in society not perceived as a threat to the Left or Right, were non-members, Charismatic Catholics, 
and Evangelicals. This is one possible explanation for the dramatic religious fragmentation within the Catholic Church, as well as the exponential growth of Evangelical Protestantism and Pentecostalism in El Salvador. The relationship between civil war, social dislocation, and diversity of religion is similar in both countries though more dramatic in El Salvador. 


\section{Chapter Seven}

\section{Conclusion}

\section{Formal Civil Society}

Formal civil society organizations, like politicians and political institutions, have failed the average Nicaraguan by making unfeasible promises and raising expectations. Formal organizations have also not truly established themselves as sources of associational activities for the aggregation of interests for the average Nicaraguan. Under the Somozas the majority of formal organizations were essentially elite organizations, as no formal organization could survive in opposition to the dictatorial regime. During the Sandinista regime the majority of formal civil society organizations, such as labor unions, were absorbed and made part of the state. Throughout the Sandinista regime the associational activities taking place failed to meet a major criterion to be considered civil society, that is working outside the state. Ironically, it is the state imposed social structures during the Sandinista regime that offer the best hope for the establishment of a formal civil society. The structure of barrio organizations, built around a "jefe" flanked by a group of community members, could serve as the infrastructure or starting point for the creation of a more stable formal civil society sector.

The findings in this research are consistent with the conclusions of Booth and Richard (1998, 796-798) on Central America inasmuch as formal civil society is not well established or defined. The majority of associational activity takes place at the community level and may not produce the effects that Putnam (2000; 1995) had hoped. For example, this research, like Booth and Richard (1998), found that even with large amounts of communal associational activity occurring, the levels of interpersonal trust 
are low. Booth and Richard (1998 797) call this a "repression affect” and claim it may not create systemic democracy, as in the past the governments co-opted communal organizations to ensure regime survival. In Nicaragua the "repression effect" occurred as a result of the muted civil society under the Somozas and the state imposed associational activities under the Sandinistas. This “repression effect” may be one of the central causes for the lack of development in formal civil society.

\section{$\underline{\text { Informal Civil Society }}$}

Outside of formal institutions, on the community or "barrio” level, associational activity thrives, both within and outside religious communities. Close physical as well as socio-economic proximity creates informal community ties through constant interaction. Thus, in Nicaragua informal civil society appears to be very healthy, which is a positive for the maintenance and establishment of democratic institutions. The strong participation and support of informal civil society activities and organizations is likely a residual effect of not only Sandinista community organizing, but also the Progressive Church organized in CEBs and the independent structure of Evangelical Protestant Churches.

The health of informal civil society within these organizations is the stating point, or basic infrastructure, to initiate the development of more healthy formal civil society organizations. Organizations or groups of grassroots churches and Evangelical movements are crucial to the establishment of formal civil society because they are institutions which provide the average Nicaraguan an opportunity to participate. Furthermore, the associational activities occurring within these types of organizations are taking place with respondents of similar socio-economic backgrounds creating an identity 
with others in the group and providing a sense of worth in their small religious communities.

\section{Religious Denomination and Civil Society}

H1. Pentecostalism will have a positive significant relationship with a civil society capable of establishing and maintaining democratic institutions.

Given the small number of Pentecostal respondents, it is impossible to make any assertion about the relationship between Pentecostal respondents and the dependent civil society variables, as their numbers were too low to make significant statistical statements.

As a result the hypothesis that Pentecostals create a civil society capable of establishing and maintaining democratic institutions is not supported here. In Nicaragua there is no evidence that Pentecostals will engender different relationships to civil society as the independent Protestant

H2. Evangelical Protestantism will have a positive significant relationship with a civil society capable of establishing and maintaining democratic institutions.

It appears Evangelical religions are no more or less capable of creating civil society I than Traditional Catholics. That is, Evangelical Protestants are no more or less capable of maintaining democratic institutions than the other denominations analyzed here. The hypothesis that Evangelical religious denominations are better at creating a civil society capable of maintaining democratic institutions is not supported. Association with Evangelical denominations provided no significant positive or negative relationships with the dependent formal and informal civil society variables, or the variables measuring the effect of participation in civil society.

H3. Traditional Catholicism will have a negative significant relationship with a civil society a capable of establishing and maintaining democratic institutions. 
Traditional Catholicism does not appear to create or hinder the development of a civil society capable of maintaining democratic institutions. The negative significant relationship between being Traditional Catholic and informal civil society support implies that being Catholic is detrimental to civil society development. However, being a Traditional Catholic increases the likelihood that respondents have confidence in governmental institutions, which is positive for the development Civil Society I. The hypothesis implying that Traditional Catholicism is less capable of producing Civil Society I is neither fully supported nor denied.

H4. Progressive Catholicism, as espoused by Liberation Theology, will have a negative significant relationship with a civil society capable of establishing and maintaining democratic institutions.

Progressive Catholicism does not appear to produce Civil Society II as previously thought. While Progressive Catholicism does not engender positive significant relationships with all of the indicators of Civil Society I, it does yield some interesting results. First, the significant positive relationship with informal civil society support shows that associational activity and organizing is occurring, which is good for producing a civil society capable of sustaining democratic political institutions. If Progressive Catholicism is producing Civil Society II, or anti regime civil society, then a significant negative relationship with the levels of confidence in governmental institutions would be expected. On the contrary, being a Progressive Catholic is a positive significant indicator of confidence in governmental institutions. Progressive Catholics are also significantly more likely to have high levels of political efficacy and interpersonal trust. If Progressive Catholicism were producing Civil Society II, then low political efficacy levels would be expected because within tyrannical regimes participation in formal political mechanisms 
like voting are ineffectual. Interpersonal trust and high political efficacy are valuable relationships for the establishment of Civil Society I. Overall, Progressive Catholicism does appear to create a pro democratic civil society. The hypothesis for Progressive Catholics creating a civil society capable of maintaining democratic institutions is supported.

H5. Charismatic Catholicism will have a positive significant relationship with a civil society capable of establishing and maintaining democratic institutions

The hypothesis regarding the capacity of Charismatic Catholicism to create a civil society capable of establishing and maintaining democratic institutions has not been supported here. This is not to say that Charismatic Catholics do not have the influence on society acknowledged by Stoll (1993). Similar to Pentecostals, the number of Charismatic Catholic respondents in this research was not sufficient for statistical analysis. There appears to have been a problem in the interview technique for determining the differences between Traditional and Charismatic Catholics. As a result, Charismatic Catholics were not coded and excluded from the study.

Overall, no religious denomination fully meets the criteria established for the creation of Civil Society I, II, or III. Progressive Catholicism is the closest, producing five positive significant relationships with the eleven civil society dependent variables. Furthermore, Progressive Catholicism does not appear to be producing Civil Society II due to its positive relationship with confidence in governmental institutions. Traditional Catholicism produces a significant negative relationship with support for informal civil society and a positive significant relationship with confidence in governmental institutions. These two relationships are not enough to determine whether Traditional Catholicism is producing Civil Society I, II, or III. Finally, the lack of any significant 
relationships between Evangelical Protestantism and the civil society dependent variables also makes it difficult to make any statements regarding the production of Civil Society I, II, or III.

Judging from the tables and analysis provided above, it appears that association within one denomination has minimal effect on either the propensity to participate in civil society or to accrue democratic values as a result of participation. The driving factors for participation in civil society outside of religious organizations are gender, education, and age.

\section{Religiosity and Civil Society}

One contribution of this study is the attempt to find alternative and comprehensive measures of religiosity and the effect of participation in religious organizations on the creation of civil society. Religiosity, as a broad construct, is difficult to measure as well as analyze. However, when the concepts of religiosity are separated, a more concrete understanding of the effects of religion begin to emerge.

Religiosity, as a broad construct, did not produce a large number of significant relationships. The level of religiosity did produce positive significant relationships with interpersonal trust and confidence in governmental institutions. These relationships are positive for the creation of Civil Society I. However, there are no significant relationships between religiosity and participation in formal or informal civil society, nor for the effects of participation measured through political efficacy, political knowledge, interpersonal trust, openness of political participation, and acceptance of alternative political expression. As a broad construct, religiosity does not provide adequate explanations for the development of Civil Society I. Age, gender, and educational 
attainment all provided more significant relationships with civil society and better explanations.

Analyzing religiosity through its three separate components, level of religious beliefs, value, and participation, produces better results. Level of religious belief has significant negative relationships with participation in formal and informal civil society. This finding may run counter to the creation of Civil Society I. According to Putnam (2000, p. 77), Evangelical churches, at least in the United States, are exclusive in nature and the associational activities occurring within them does not spread outside of those institutions. Evangelicals in this research have significant positive relationships with all of the independent religiosity variables, suggesting the highest levels of religiosity are among Nicaraguan Evangelicals. If informal civil society is occurring within independent Evangelical churches in Nicaragua, then a negative relationship between religious belief and participation in formal and informal civil society shows that participation in these Evangelical Church comes at the expense of other civil society actors, both formal and informal. That is, the more time spent within the Evangelical Churches, the less time dedicated to other civil society actors. The implication here is that Evangelicals in Nicaragua are also exclusive, keeping the benefits of associational activity within their church communities. This does not explain the lack of significant relationships between Evangelical denominations and the dependent civil society variables.

The level of religious value finds no statistically significant relationships with the dependent civil society variables or the effects of civil society. However, the level of religious participation shows both positive and negative relationships. The significant 
positive relationships between religious participation and informal civil society participation are good for the development of Civil Society I. Religious participation generates informal civil society participation, which produces attitudes necessary for the development of confidence in governmental institutions.

The problem in making this assertion is the negative significant relationship between religious participation and the levels of political knowledge and openness of political participation. These relationships suggest that confidence in governmental institutions is based on a lack of knowledge about politics, creating a false sense of confidence. This relationship is further evidence that people who participate in religion do so out of a desire to escape the hardships of daily life. Religious participation may produce an avoidance of politics, as noted by the relationship with political knowledge. Religious participation may also produce conservative attitudes encouraging maintenance of the status quo. The motivation behind these attitudes is to avoid political conflict and violence, as shown by the significant negative relationship with the openness of political participation.

The most intriguing findings are the relationships between the view of religious success in society and the role respondents believe religious institutions should play in the social, political, and economic sphere. These findings are significant because they demonstrate a relationship in attitudes towards religious institutions being reflected in the attitudes towards political institutions.

If respondents believe religious institutions should play a major role in society, then respondents are more likely to participate in and support informal civil society. They are also more likely to have high political efficacy and believe in the openness of 
political participation. The implication of this relationship is that if religious institutions are playing a major role in society, respondents are empowered by this role and are producing attitudes that encourage political efficacy and open political processes. These relationships are positive for the production of Civil Society I, as the more political efficacy respondents have, the more likely they are to invest in society through participation.

Respondent's views regarding the success of religious institutions also illustrate a noteworthy relationship. The respondents' view of success among religious institutions in society has significant positive relationships with political efficacy, interpersonal trust, confidence in governmental institutions, and belief that governmental institutions are correct. These relationships suggest that if respondents view religious institutions as successful, they also view other institutions as successful. Respondents in Nicaragua are much closer to their religious institutions than their political ones. Positive attitudes about religious institutions among respondents may foster positive attitudes about political institutions, which is encouraging for the creation of Civil Society I.

The relationships of attitudes towards religious institutions affecting attitudes about other political and social institutions are significant. They demonstrate that even though religious institutions have fragmented and denominational affiliation is in transition, religious institutions remain the central social institutions in the lives of most Nicaraguans. Whether it comes from the hierarchy of the Traditional Catholic Church or the grassroots model of Evangelical Protestantism and Progressive Catholicism, religious institutions are among the most important in society. The evidence presented here supports the assertions of Inglehart and Norris' (2004) that traditional societies in 
underdeveloped states are not following the secularization model of developed world. The state of "human development" in such countries means religious organizations fill the voids in civil society where other private and governmental institutions cannot provide solutions to daily problems. Nicaragua is no exception to these claims, especially when the relationship between the role of religion in society and the effects of civil society are taken into consideration.

\section{Control Variables and Civil Society}

Education seems to be the most significant variable when trying to gain an understanding of civil society development and its effects. Unfortunately, this fact does not bode well for the future of Nicaragua, as many of today's youth are foregoing formal education due to a lack of opportunity upon graduation and the immediate economic needs of the family. To develop Civil Society I, it is important that an educated and caring population is being fostered. Success utilizing the organizational capacity of informal civil society established through the Sandinista regime and the grassroots organization of popular religious organization for the development of formal civil society will be the responsibility of the next generation. If educational attainment continues its downward trend and poor economic performance persists, the future for the next generation appears bleak. With little incentive existing to educate themselves today, the future of civil society development is in danger as the burden on already strapped religious, social, and political institutions, as well as other civil society actors, will increase.

\section{Need for Further Investigation}


The findings of this research add to the theoretical literature surrounding the role of religion in politics, and civil society, however the results are not uniformly robust, and leave room for further analysis. First the relationship between religion and democracy needs to be further explored. The idea that Catholicism, due to its structure and mediated relationship with God is anti-democratic, put forth by Weber, Lipset, Barro, and Huntington, is not as strong today as in the past. That is, as religious institutions, like the Catholic Church and many of the mainline Protestant denominations, have fragmented, the uniformity of their message has also fragmented. The belief that religious institutions provide the framework through which individuals can interpret their increasingly complex world (Inglehart 1988; Wald, Owen and Hill 1990; 1988; Griffith, Plamentz, and Pennock 1956) may be true, but making generalizations by denomination is less relevant.

As Gill(1999; 1994) and Iannacone, Fink, and Stark(1997) have pointed out, the decline of the Catholic monopoly in Latin America has led to an open religious market where Evangelical Protestant denominations are working to establish themselves. Furthermore, Cleary (1997) finds that these new Evangelical Protestant denominations are not mirror images of their sister denominations to the north. These independent Evangelical churches are built on "survival strategies" where religious leaders are not only charged with providing the weekly biblical lessons, but also recruiting members and raising funds. Through these duties the consistency of religious belief by denomination is altered by each specific religious leader in their survival efforts. Thus, the religious message is inconsistent across individual churches and within denominations. Due to this 
inconsistency, making statements about large sections of society by denomination becomes a difficult task.

Modernization has also changed the impact of religion on the individual. Nicaragua is one of the poorest states in the Western Hemisphere, yet technological development has increased the accessibility of television and radio to all sectors of society. Accessibility to these technologies has decreased the importance of religious organizations as the providers of political information necessary for the creation political beliefs. These findings do not deny that religion is not an important part of society. Religious organizations and institutions are extremely important sources of community and arenas where spirituality is developed. The political role of religious organizations is shifting, especially in developing countries, where they are used as escapes from the harshness of the real world rather than the primary interpreters of it.

To understand the role of religion and politics, research needs to move beyond the typologies of religious denomination and religiosity to a more comprehensive understanding of how people apply their religious beliefs and knowledge in everyday life. Religion itself is an interpretation of some religious document or set of principles; as people submit themselves to those rules, they also engage in interpretation. Therefore, application of religion in daily life is not done uniformly. People with different levels of belief and knowledge will apply their religious background in different ways based on what they know. The result is a different worldview based on attitudes towards society and politics interpreted through their religious knowledge and religious communities.

Development of formal civil society in Nicaragua is possible if formal civil society actors are able to revitalize or replicate the local organizing infrastructure created 
by the Sandinista regime and popular religious organizations. Further research needs to examine what is left of former barrio level community organizing and revitalize it in more pro democratic forms. Research also needs to explore ways to incorporate the small and exclusive independent Evangelical Churches, as well as other churches, in ways that allow them to effectively participate in civil society. The structure of these small communities created inside Evangelical Churches also needs more exploration to understand the nature of their exclusivity and find ways to incorporate these small communities into the broader civil society arena. 


\section{Bibliography}

Ai Camp, Roderic Politics in Mexico: The Decline of Authoritarianism Oxford University Press, New York, N.Y.

Almond, Gabriel A., Verba, Sydney The Civic Culture: Political Attitudes and Democracy in Five Countries Princeton University Press. Princeton N. J. 1963

Alvarez, Sonia, Evelina Dagnino, and Arturo Escobar "The Cultural and the Political in Latin American Social Movements”. In Cultures of Politics/Politics of Cultures: Re-visioning Latin American Social Movements, ed. Alvarez, Dagnino, and Escobar. Boulder: Westview Press. 1998

Barro, Robert J. “Determinants of Democracy: Journal of Political Economy, Volume 107, Number 6, 1999, p. 158-183

Bastian, Jean-Pierre; Cunneen, Joseph “The New Religious Map of Latin America: Causes and Social Effects” Cross Currents, Volume 48, Issue 3, Fall 1998

Belli, Humberto Breaking the Faith: The Sandinista Revolution and Its Impact on Freedom and Christian Faith In Nicaragua The Puebla Institute, Garden City, MI, 1985

Bohning, Don “One Disaster Recalls Another: 1972 Earthquake’s Effects Still Felt” The Miami Herald, November 3, 1998 down loaded from http//:www.latinamericanstudies.org/Nicaragua/earthquake.htm

Booth, John A. and Patricia Bayer Richard “Civil Society, Political Capital, and Democratization in Central America” The Journal of Politics, Volume 60, Issue 3 (August 1998), p.780-800

Brysk, Alison “Democratizing Civil Society in Latin America” Journal of Democracy Volume11, Issue 3, 2000, p.151-165

Campos M., Bernardo “Chapter 1: Pentecostalism, Theology and Social Ethics” In the Power of the Spirit edited by Dennis A. Smith and B.F. Guiterrez, Presbyterian Church (USA) 1996 p.41-50. Downloaded from www.religion-online.org

Casanova, Jose "Civil Society and Religion: Retrospective Reflections on Catholicism and Prospective Reflections on Islam” Social Research, Volume 68, No. 4, Winter 2001, p.1041-1080

Castles, Francis G. Comparative Public Policy: Patterns of Post-war Transformation Edward Elgar Publishers, Cheltenham UK, 1998 
Castles, Francis G. Family of Nations: Patterns of Public Policy in Western Democracies Brookfield Pub. NH: Dartmouth 1993

Chavez, Joaquin M. NACLA Report on the Americas, Volume 37 Issue 6, May/Jun2004, p.31-39

Chestnut, Andrew R. Born Again in Brazil: The Pentecostal Boom and the Pathogens of Poverty Rutgers University Press, 1997

Cleary, Edward L. "Protestant Political Engagement and Disengagement In Lating America” Paper presented as The Political Implications of the Rise In Protestantism In Latin America Conference at the Brookings Institutions, Washington D.C. 1999 Downloaded from http://www.providence.edu/las/Brookings.html

Cleary, Edward L. "Evangelicals and Competition in Guatemala" Conflict and Competition: The Latin American Church in a Changing Environment edited by Edward Cleary/Hanna Steward-Gambino Lynne Reinner Publishers, Boulder CO, 1992 p.234 Downloaded from http://www.dominicans.org/ ecleary/conflict/conflict07.htm

Cleary, Edward L. "Conclusion: Politics and Religion-Crisis, Constraints, and Restructuring" Conflict and Competition: The Latin American Church in a Changing Environment edited by Edward Cleary/Hanna Steward-Gambino Lynne Reinner Publishers, Boulder CO, 1992 p.234 Downloaded from http://www.dominicans.org/ ecleary/conflict/conflict07.htm

CIA World Fact Book, 2004 http://www.cia.gov/cia/publications/factbook/geos/nu.html\#Govt

Cuadra, S, “Closing Down a Polluter”, World Press Review May 1992 Volume 39, Issue 5, p. 47-53

Dahl, Robert A. Polyarchy: Participation and Opposition Yale University Press, New Haven CT, 1971

Darlington, Richard B. The information regarding factor analysis was downloaded from http://www.psych.cornell.edu/Darlington/factor.htm

Daudelin, Jean; Hewitt, W.E. "Churches and Politics in Latin America: Catholicism at the Cross Roads” Third World Quarterly Volume 16, June 1995, p. 221-236

Deonandan, Kalowatie “The Lost Mission of Nicaragua’s 'Popular Church”” Peace Review Volume 13, Issues 3, 2001, p. 449-455 
De Tocqueville, Alexis Democracy in America Edited and Abridged by Richard D. Heffner, The Penguin Group, New York, NY, 1984

Directory of Water Resources Organizations In The Americas, 2004, Volume 2, Downloaded from: www.iwrn.net

Drogus, Carol Ann "Popular Movements and the Limits of Political Mobilization at the Grassroots in Brazil" in Conflict and Competition: The Latin American Church in a Changing Environment edited by Edward L. Cleary and Hanna StewartGambino Lynne Reinner Publishers, Boulder CO, 1992, p. 234 Downloaded from http://www.dominicans.org/ ecleary/conflict/conflict07.htm

Filmer,Deon "Educational Attainment and Enrollment Profiles: A Resource Book based on an Analysis of Demographic and Health Survey Data”. Mimeo. Development Research Group. The World Bank. 2003 http://www.worldbank.org/research/projects/edattain/profiles/nic4/datasheet.txt

Foley, Michael W. and Bob Edwards “The Paradox of Civil Society” Journal of Democracy Volume 7 Issue 3, 1996, p. 38-52

Fukuyama, Francis "The Primacy of Political Culture” Journal of Democracy Volume 6 Issue 1 1995, p.7-14

Fukuyama, Francis The End of History and the Last Man Avon Publishers, New York, NY, 1992

Galston, William A. “Civil Society and the ‘Art of Association’” Journal of Democracy Volume 11 Issue 1, 2000, p. 64-70

Garrard-Burnett, Virginia, and David Stoll Rethinking Protestantism in Latin America Temple University Press, 1993

Gellner, Ernest Conditions of Liberty: Civil Society and Its Rivals The Penguin Press, 1994

Gill, Anthony "Government Regulation, Social Anomie, and Protestant Growth in Latin America” Rationality and Society, Volume 11, August. 1999 p.288-313

Gill, Anthony "Rendering unto Caesar? Religious Competition and Catholic Political Strategy in Latin America, 1962-79” American Journal of Political Science, Volume 38, Issue 2, May 1994, p. 403-425

Gorusch, Richard L. "Religious Aspects of Substance Abuse and Recovery" Journal of Social Issues Volume 51, Number 2, Summer 1995 
Griffith, Ernest S; Plamenatz, John; Pennock, J. Roland "Cultural Prerequisites to a Successfully Functioning Democracy: A Symposium” American Political Science Review, Volume 50, Issue 1, March 1956 p.101-137

Huntington, Samuel P. Clash of Civilizations and the Remaking of World Order Touchstone, New York, 1997

Huntington, Samuel P. The Third Wave: Democratization in the Late Twentieth Century University of Oklahoma Press: Norman, Oklahoma. 1991

Iannaccone, Laurence, R; Roger Finke and Rodney Stark "Deregulating Religion: The Economics of Church and State” Economic Inquiry Vol. XXV, April 1997, p. $350-364$

Inglehart, Ronald “The Renaissance of Political Culture” American Political Science Review, Volume 82, Issue 4, December 1988, p. 1203-1230

Inglehart Ronald, Miguel Basañez, Jaime Díez-Medrano, Loek Halman and Ruud Luijkx (ed.) Human Beliefs and values. A Cross-Cultural Sourcebook Based on the 1999-2002 values surveys Siglo XXI Editores, 2004

Inglehart, Ronald and Norris, Pippa Sacred and Secular: Religion and Politics World Wide Cambridge University Press, November 2004 pp. 348

Ireland, Rowan Popular "Religions and the Building of Democracy in Latin America: Saving the Tocquevillian Parallel" Journal of Interamerican Studies and World Affairs, Volume 41, Issue 4, Winter 1999, p. 111

Jacobs, Janet "Deconversion "From Religious Movements: An Analysis of Charismatic Bonding and Spiritual Commitment” Journal for the Scientific Study of Religion Volume 26, Issue 3, 1987, p. 294-308

Jelen, Ted G. "Political Christianity: A Contextual Analysis” American Journal of Political Science Volume 36, Issue 3, Aug. 1992, p. 692-714

Karliner, Joshua N, Daniel Faber “The Other Revolution: Nicaragua’s Environmental Crisis” Utne Reader; Issue 25, Jan/Feb 1988, p. 54-66.

Kirk, John M. Politics and the Catholic Church in Nicaragua, University of Florida Press, Gainesville, FL, 1992

Lancaster, Roger. Thanks to God and the Revolution: Popular Religion and Class Consciousness in the New Nicaragua. Columbia University Press 1988 p. 280

Levine, Daniel H. Popular Voices in Latin American Catholicism.: Princeton University Press. 1992 
Levine, Daniel H. "Popular Groups, Popular Culture, and Popular Religion” Comparative Studies in Society and History Volume 32, Number 4, Oct. 1990, p. 718-764

Linz, Juan J. and Alfred Stepan “Toward Consolidated Democracies” Journal of Democracy Volume7 Issues 2, 1996, p. 14-33

Lipset, Seymour Martin “The Social Requisites of Democracy Revisited: 1993 Presidential Address” American Sociological Review Volume 59, Issue 1, February 1994, p. 1-22.

Lyderson, Kari "Grim News in Central America” Resource Center for the Americas January 29, 2004 Downloaded from: http://www.americas.org/item_12

Lynch, Edward A. "Reform and Religion in Latin America” Orbis, Vol. 42 Issue 2, Spring 1998, p. 263, 18p.

Martin, David. Tongues of Fire: The Explosion of Protestantism in Latin America. Oxford: Blackwell. 1990

Mariz, Cecilia Loreto and Maria Das Dores Campos Machado "Pentecostalism and Women in Brazil" in Power Politics and Pentecostals in Latin America edited by Edward L. Cleary and Hannah W. Steward Cambino West View Press 1998, p. 261

Mihaly, Aaron “Nicaragua Seminar Trip” ReVista: Harvard Review of Latin America, Fall 2002

Ministerio Agropecuario y Forestal (MAGFOR), 2004, Downloaded from: www.magfor.gob.ni

Ministerio Del Ambiente y Recursos Naturales (MARENA), 2004, Downloaded from: www.marena.gob.ni

Muller, Edward N. and Mitchel A. Seligson "Civic Culture and Democracy: The Question of Causal Relationships” American Political Science Review, Volume 88, Issue 3, September 1994, p. 635-652

Muller, Edward M., Thomas O. Jukam, Mitchell A. Seligson "Diffuse Political Support and Antisystem Political Behavior: A Comparative Analysis” American Journal of Political Science, Volume 26, Issue 2, May 1982, p. 240-264

Mulligan, Joseph E. S.J. The Nicaraguan Church and the Revolution Sheed and Ward Publishers, Kansas City, MO 1991 
O’Donnell, Guillermo and Philippe C. Schmitter Transitions from Authoritarian Rule: Tentative Conclusions about Uncertain Democracies John Hopkins University Press, Baltimore, MD 1986

Pateman, Carol Participation and Democratic Theory Cambridge University Press 1970,

Patterson, Eric "Different Religions, Different Politics? Religion and Political Attitudes in Argentina and Chile" Journal for the Scientific Study of Religion Volume 43, Issue 3 (2004) p. 345-362

Przeworski, Adam; Limongi, Fernando "Modernization: Theories and Facts” World Politics Volume 49, Issue 2, p. 155-183

Putnam, Robert D. Bowling Alone: The Collapse and Revival of American Community Simon \& Schuster, New York, New York. 2000

Putnam, Robert D. "Bowling Alone: America's Declining Social Capital” Journal of Democracy 1995 Volume 6 Issue 1 p.65-78

Putnam, Robert D. Making Democracy Work: Civic Tradition in Modern Italy Princeton University Press, Princeton NJ, 1994

Reichley, Richard. Religion in American Public Life Brookings Institute, Washington D. C. 1985

Rodgers, Dennis “We Live in a State of Siege:” Violence, Crime and Gangs In PostConflict Urban Nicaragua” Working Paper Series: Development Studies Institute at the London School of Economics and Political Science, London, No.02-36, September 2002 Downloaded from: http://www.lse.ac.uk/collections/DESTIN/pdf/WP36.pdf

Rogers, Tim “Central America Takes Harder Line Against Gangs” Christian Science Monitor, July 06, 2004 http://www.csmonitor.com/2004/0706/p07s02-woam.htm

Ross, Oakland “A City of 2 Million Without a Map” World Press Review Volume 49 Issue 7, July 2002, p. 44

Rueschemeyer, Dietrich, "The Self-Organization of Society and Democratic Rule” Participation and Democracy East and West: Comparisons and Interpretations Edited by Dietrich Rueschemeyer, Marilyn Rueschemeyer, and Bjorn Wittrock M.E. Sharp, London, 1998

Sabia, Debra_Contradiction and Conflict: The Popular Church In Nicaragua University of Alabama Press 
Sawchuk, Dana "The Catholic Church in the Nicaraguan Revolution; A Gramscian Analysis” Sociology of Religion Volume 58, Issue 1, 1997, p. 39-51

Schneider, Ellen “Nicaraguan Democracy”, ReVista: Harvard Review of Latin America, Fall 2002

Seligman, Adam B. The Idea of Civil Society The Free Press NY, NY 1992

Seligson, Amber L. “Civic Association and Democratic Participation in Central America: A Test of the Putnam Thesis" Comparative Political Studies, Volume 32, Number 3, May 1999, p.342-362

Seligson, Mitchell A., Booth John A. "Political Culture and Regime Type: Evidence from Nicaragua and Costa Rica” Journal of Politics, Volume 55, Issue 3, August 1993, p.777-792

Smith, Christian and Liesl Ann Haas "Revolutionary Evangelicals in Nicaragua: Political Opportunity, Class Interests, and Religious Identity” Journal for the Scientific Study of Religion, Volume 36, Issue 3, September 1997

Stein, Andrew J., Religious Actors in El Salvador Since 1992 Paper Presented at the XXI International Congress of the Latin American Studies Association, Chicago IL, September 24-26, 1998 p. 16

Stoll, David Is Latin America Turning Protestant?: The Politics of Evangelical Growth University of California Press, 1990

Torres, Carlos Alberto; Young, Richard A. The Church, Society, and Hegemony: A Critical Sociology of Religion in Latin America Greenwood Publishing 1992

U. S. Department of State “Profile of Nicaragua” www.state.gov/r/pa/ei/bgn/1850.htm

Vasquez, Manual A. "Toward A New Agenda for the Study of Religion in the Americas" Journal of Interamerican Studies \& World Affairs Winter 99, Vol. 41 Issue 4 p.1

Verba, Sidney, Nie Norman H., \& Kim, Je-on Participation and Political Equality: A Seven-Nation Comparison. Cambridge University Press 1978

Vision Mundial (World Vision International) Downloaded from http://www.wvi.org/wvi/home.htm

Wald, Kenneth D.; Shye, Samuel, "Religious Influence on Electoral Behavior: The Role of Institutional and Social Forces in Israel” Journal of Politics Volume 57, Issue 2, May 1995, p. 495-507. 
Wald, Kenneth D.; Owen, Dennis; Hill, Samuel "Political Cohesion in Churches" The Journal of Politics Volume 52, Number 1, February 1990, p. 197-215

Walker, Thomas W., Nicaragua: Living in the Shadow of the Eagle $4^{\text {th }}$ Edition, Westview Press, Cambridge MA, 2003

Weber, Max The Protestant Ethic and the Spirit of Capitalism, translated by G. Allen, Charles Scribner's and Sons, 1934

Welch Michael R.; David Sikkink; Eric Sartain, and Carolyn Bond "Trust in God and Trust in Man: The Ambivalent Role of Religion in Shaping Dimensions of Social Trust” Journal for the Scientific Study of Religion Volume 43: Issue 3, 2004, pp. 317-343

Willems, Emilio. Followers of the New Faith: Culture Change and the Rise of Protestantism in Brazil and Chile. Vanderbilt University Press 1967

Williams, Phillip “The Limits of Religious Influence: The Progressive Church in Nicaragua” Conflict and Competition: The Latin American Church in a Changing Environment edited by Edward L. Cleary and Hanna Stewart-Gambino. Lynne Reinner Publishers, Boulder CO, 1992 p.234 Downloaded from http://www.dominicans.org/ ecleary/conflict/conflict07.htm

Williams, Philip J. "The Sounds of Tambourines": The Politics of Pentecostal Growth in El Salvador" in Power, Politics, and Pentecostals in Latin America edited by Edward L. Cleary and Hannah H. Stewart-Gambino, Westview Press, Boulder CO, 1998, p. 179-200

Williams, Philip J.; Peterson, Anna Lisa "Evangelicals and Catholics in El Salvador: Evolving Religious Responses to Social Change” Journal of Church and State Volume 38, Issue 4, Autumn1996, p. 873-897. 
Appendix 1: Code Book for the 2003 Nicaraguan Survey Instrument 
Code Book for the 2003 Nicaraguan Survey Instrument - John G. Poffenbarger

1. Number - the number of the survey

2. Date

3. Start Time

4. End Time

5. Neighborhood

6. Rural (1) or Urban (2)

\section{Political Participation (PP---)}

7.A) Do you vote in National Elections (PPVNE)

\begin{tabular}{|l|l|}
\hline Almost (5) & \\
\hline Almost Always (4) & \\
\hline Sometimes (3) & \\
\hline Almost Never (2) & \\
\hline Never (1) & \\
\hline DK (99) & \\
\hline NA (88) & \\
\hline
\end{tabular}

7.B. Do you vote in Local Elections? (PPVLE)

\begin{tabular}{|l|l|}
\hline Almost (5) & \\
\hline Almost Always (4) & \\
\hline Sometimes (3) & \\
\hline Almost Never (2) & \\
\hline Never (1) & \\
\hline DK (99) & \\
\hline NA (88) & \\
\hline
\end{tabular}

Show Card B.

7C. Did you vote in the elections held on November 4, 2001? (PPVRE)

\begin{tabular}{|l|l|}
\hline Yes (2) & \\
\hline No (1) & \\
\hline DK (99) & \\
\hline NA (88) & \\
\hline
\end{tabular}

7C1. (If no on 7C). I am going to read a series of statements. Please indicate which of the following as reasons for not voting in the last election (PPRNV\#)

1. I am not interested in politics or government.(PPRNV1

2. The same party always wins (PPRNV2)

3. Nothing ever changes (PPRNV3)

4. Important issues were never addressed. (PPRNV4)

5. Did not know there was an election (PPRNV5)

6. I did not know where to vote (PPRNV6)

7. I did not agree with any of the candidates (PPRNV7)

8. I did not have an identification card (PPRNV8)

9. My registration card did not match my polling place. (PPRNV9)

10. I was busy (PPRNV10)

11. I forgot (PPRNV11)

12. I was ill (PPRNV12)

13. I did not have sufficient information to decide on a candidate (PPRNV13)

14. Other reasons: (PPRNV14)

Yes (2) No (1) DK(99) NA(88)

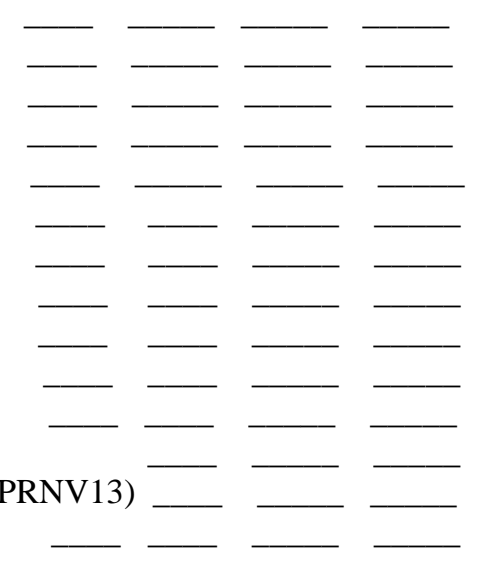

7D Have you ever worked for a candidate or party?

$$
\text { Yes (2) }
$$




\begin{tabular}{|l|l|}
\hline No (1) & \\
\hline DK (99) & \\
\hline NA (88) & \\
\hline
\end{tabular}

7E. Have you ever tried to convince others how to vote? (PPCOV)

\begin{tabular}{|l|l|}
\hline Yes (2) & \\
\hline No (1) & \\
\hline DK (99) & \\
\hline NA (88) & \\
\hline
\end{tabular}

\section{Show card C}

7E1. If yes on 7E, How frequently have you tried to convince other how to vote? (PPFCV)

Show Card B

\begin{tabular}{|l|l|}
\hline Very Frequently (5) & \\
\hline Frequently (4) & \\
\hline Occasionally (3) & \\
\hline Rarely (2) & \\
\hline Never (1) & \\
\hline DK (99) & \\
\hline NA (88) & \\
\hline
\end{tabular}

7G. What do you consider to be most important when deciding whom to vote for? (PPIID)

\begin{tabular}{|l|l|l|l|l|}
\hline & Yes (1) & No (0) & DK (99) & NA(88) \\
\hline Party (PPIIDP) & & & & \\
\hline Candidate (PPIIDC) & & & & \\
\hline $\begin{array}{l}\text { Plan of Government } \\
\text { (PPIIDG) }\end{array}$ & & & & \\
\hline
\end{tabular}

Political Knowledge (PK---)

8A.) Who is the president of Nicaragua? (PKPRN)

\begin{tabular}{|l|l|}
\hline Knows (2) & \\
\hline Does not know (1) & \\
\hline DNA (99) & \\
\hline NA(88) & \\
\hline
\end{tabular}

8B.) Who is the President of the United States? (PKPUS)

\begin{tabular}{|l|l|}
\hline Knows (2) & \\
\hline Does not know (1) & \\
\hline DNA (99) & \\
\hline NA(88) & \\
\hline
\end{tabular}

8C.) Who is the mayor of your city or town? (PKMCT)

\begin{tabular}{|l|l|}
\hline Knows (2) & \\
\hline Does not know (1) & \\
\hline DNA (99) & \\
\hline NA(88) & \\
\hline
\end{tabular}

\section{Formal Civil Society (FOC--)}

\section{Show Card D}

For each of the following organizations please indicate whether you are: Very active member (4); Active Member (3) Somewhat active member (2); Inactive Member (1); Not a Member (0); DK (99)

9A.) Sports or recreation organization? (FOCSR)

\begin{tabular}{|l|l|}
\hline Very Active Member (5) & \\
\hline Active Member (4) & \\
\hline Somewhat Active Member (3) & \\
\hline
\end{tabular}




\begin{tabular}{|l|l|}
\hline Inactive Member (2) & \\
\hline Not a Member (1) & \\
\hline DK (99) & \\
\hline NA (88) & \\
\hline
\end{tabular}

9A1) If yes, what sports or recreational activities do you take part in? (FOCSR1)

9A2) If yes, how many times per month do you take part in these activities? (FOCSR2)

9A3) Other than sports what other recreational activities do you participate in? (FOCSR3)

9B) Art, music, or educational organizations? (FOCAM)

\begin{tabular}{|l|l|}
\hline Very Active Member (5) & \\
\hline Active Member (4) & \\
\hline Somewhat Active Member (3) & \\
\hline Inactive Member (2) & \\
\hline Not a Member (1) & \\
\hline DK (99) & \\
\hline NA (88) & \\
\hline
\end{tabular}

9B1.) If yes, what are these organizations? (FOCAM1)

9B2.) If yes, how many times in a month do you participate in activities with this (these) organization(s)? (FOCAM2)

9C.) Labor Unions (FOCLU)

\begin{tabular}{|l|l|}
\hline Very Active Member (5) & \\
\hline Active Member (4) & \\
\hline Somewhat Active Member (3) & \\
\hline Inactive Member (2) & \\
\hline Not a Member (1) & \\
\hline DK (99) & \\
\hline NA (88) & \\
\hline
\end{tabular}

9C1.) If yes, what is the name of this labor union? (FOCLU1)

9C2.) If yes, how often does this organization meet? (FOCLU2)

9D.) Political Party (FOCPP)

\begin{tabular}{|l|l|}
\hline Very Active Member (5) & \\
\hline Active Member (4) & \\
\hline Somewhat Active Member (3) & \\
\hline Inactive Member (2) & \\
\hline Not a Member (1) & \\
\hline DK (99) & \\
\hline NA (88) & \\
\hline
\end{tabular}

9D1.) If yes, what is the name of the political party? (FOCPP1)

9D2.) If yes, how often do you attend party meetings? (FOCPP2)

9E.) Environmental Organization (FOCEO)

\begin{tabular}{|l|l|}
\hline Very Active Member (5) & \\
\hline Active Member (4) & \\
\hline Somewhat Active Member (3) & \\
\hline Inactive Member (2) & \\
\hline Not a Member (1) & \\
\hline DK (99) & \\
\hline NA (88) & \\
\hline
\end{tabular}

9E1.) If yes, what is the name of the environmental organization? (FOCEO1)

9E2.) If yes, how frequently do you attend meetings of this organization (FOCEO2)

9F.) Professional Association (FOCPA) 


\begin{tabular}{|l|l|}
\hline Very Active Member (5) & \\
\hline Active Member (4) & \\
\hline Somewhat Active Member (3) & \\
\hline Inactive Member (2) & \\
\hline Not a Member (1) & \\
\hline DK (99) & \\
\hline NA (88) & \\
\hline
\end{tabular}

9F1.) If yes, what is the name of this professional association? (FOCPA1)

9F2.) If yes, how often do you attend meetings of this professional association? (FOCPA2)

9G.) Charitable or Philanthropic Organization (FOCCP): for example the Rotary Club

\begin{tabular}{|l|l|}
\hline Very Active Member (5) & \\
\hline Active Member (4) & \\
\hline Somewhat Active Member (3) & \\
\hline Inactive Member (2) & \\
\hline Not a Member (1) & \\
\hline DK (99) & \\
\hline NA (88) & \\
\hline
\end{tabular}

9G1.) If yes, what is the name of the organization? (FOCCP1)

9G2.) If yes, how frequently do you attend meetings of this organization? (FOCCP2)

9G3.) Are these organizations affiliated with any religious organizations? (FOCCP3)

\begin{tabular}{|l|l|}
\hline Yes (2) & \\
\hline No (1) & \\
\hline DK (99) & \\
\hline NA (88) & \\
\hline
\end{tabular}

9G4.) If yes (to 9G3), what religious organization(s) are they affiliated with? (FOCCP4) 9H.) Do you belong to any other organizations? What is/are their name(s)?

\section{Informal Civil Society (IOC--)}

\section{Show Card B}

10A.) Do you belong to any groups in your community or neighborhood associations? (IOCCG)

\begin{tabular}{|l|l|}
\hline Yes (2) & \\
\hline No (1) & \\
\hline DK (99) & \\
\hline NA (88) & \\
\hline
\end{tabular}

10A1.) If yes, what activities or services do these groups offer? (IOCCG1)

10A2.) If yes, how often do these groups meet? (IOCCG2)

10A3.) Are these groups affiliated with religious organizations? (IOCCG3)

\begin{tabular}{|l|l|}
\hline Yes (2) & \\
\hline No (1) & \\
\hline DK (99) & \\
\hline NA (88) & \\
\hline
\end{tabular}

10B.) Have you ever worked or tried to resolve a community problem or a problem of one of the members of your community? (IOCCP)

\begin{tabular}{|l|l|}
\hline Yes (2) & \\
\hline No (1) & \\
\hline DK (99) & \\
\hline NA (88) & \\
\hline
\end{tabular}

10B1.) If yes, what problems did you try to resolve? (IOCCP1)

10B2.) If yes, were these problems resolved satisfactorily? (IOCCP2) yes: in part; no 


\begin{tabular}{|l|l|}
\hline Yes (3) & \\
\hline In part (2) & \\
\hline No (1) & \\
\hline DK (99) & \\
\hline NA (88) & \\
\hline
\end{tabular}

10C.) Have you ever donated money or materials to solve a problem, or to improve the community? (IOCDM)

\begin{tabular}{|l|l|}
\hline Yes (2) & \\
\hline No (1) & \\
\hline DK (99) & \\
\hline NA (88) & \\
\hline
\end{tabular}

10C1.) If yes, what sort of assistance did you provide? (IOCDM1)

10D.) Have you ever donated your work to solve a problem or to improve the community? (IOCDW)

\begin{tabular}{|l|l|}
\hline Yes (2) & \\
\hline No (1) & \\
\hline DK (99) & \\
\hline NA (88) & \\
\hline
\end{tabular}

10D1.) If yes, what sort of assistance did you provide? (IOCDW1)

10E.) Have you ever attended a meeting about a problem of or improvement to the community? (IOCAM)

\begin{tabular}{|l|l|}
\hline Yes (2) & \\
\hline No (1) & \\
\hline DK (99) & \\
\hline NA (88) & \\
\hline
\end{tabular}

10E1.) If yes (10E), how many time or often have you done this? (IOCAM1)

10E2.) If yes (10E), who attended these meetings? (IOCAM2)

10E3.) If yes (10E), what problems were being discussed? (IOCAM3)

10E4.) If yes (10E), where these problems resolved satisfactorily? (IOCAM4)

\begin{tabular}{|l|l|}
\hline Yes (3) & \\
\hline In part (2) & \\
\hline No (1) & \\
\hline DK (99) & \\
\hline NA (88) & \\
\hline
\end{tabular}

10E5.) If yes (10E), does this group still meet today? (IOCAM5)

\begin{tabular}{|l|l|}
\hline Yes (2) & \\
\hline No (1) & \\
\hline DK (99) & \\
\hline NA (88) & \\
\hline
\end{tabular}

10F.) Have you ever helped organize a group to solve a local problem or to search for an improvement to the community? (IOCNG)

\begin{tabular}{|l|l|}
\hline Yes (2) & \\
\hline No (1) & \\
\hline DK (99) & \\
\hline NA (88) & \\
\hline
\end{tabular}

10F1.) If yes (10F), how many time or often have you done this? (IOCNG1)

10F2.) If yes (10F), who attended these meetings? (IOCNG2)

10F3.) If yes (10F), what problems were being discussed? (IOCNG3)

10F4.) If yes (10F), where these problems resolved satisfactorily? (IOCNG4)

\begin{tabular}{|l|l|}
\hline Yes (3) & \\
\hline In part (2) & \\
\hline No (1) & \\
\hline DK (99) & \\
\hline NA(88) & \\
\hline
\end{tabular}

10F5.) If yes (10F), does this group still meet today? (IOCNG5)

$$
\text { Yes (2) }
$$




\begin{tabular}{|l|l|}
\hline No (1) & \\
\hline DK (99) & \\
\hline NA (88) & \\
\hline
\end{tabular}

\section{Interpersonal Trust (ITP--)}

\section{Show Card E}

I am going to read a series of statements, for each statement pleas indicate whether you: Strongly Agree; Agree; Neither agree nor disagree; Disagree; Strongly Disagree ; Do not know

11A.) I find that in general people are trustworthy (IPTGT)

\begin{tabular}{|l|l|}
\hline Strongly Agree (5) & \\
\hline Agree (4) & \\
\hline Neither Agree nor disagree (3) & \\
\hline Disagree (2) & \\
\hline Strongly Disagree (1) & \\
\hline DK (99) & \\
\hline NA (88) & \\
\hline
\end{tabular}

11B.) Most of the time people only worry about themselves. (IPTWT)* CODE IN REVERSE

\begin{tabular}{|l|l|}
\hline Strongly Agree (5) & \\
\hline Agree (4) & \\
\hline Neither Agree nor disagree (3) & \\
\hline Disagree (2) & \\
\hline Strongly Disagree (1) & \\
\hline DK (99) & \\
\hline NA (88) & \\
\hline
\end{tabular}

11C.) Most of the time people try to help other people. (IPTHO)

\begin{tabular}{|l|l|}
\hline Strongly Agree (5) & \\
\hline Agree (4) & \\
\hline Neither Agree nor disagree (3) & \\
\hline Disagree (2) & \\
\hline Strongly Disagree (1) & \\
\hline DK (99) & \\
\hline NA (88) & \\
\hline
\end{tabular}

11D.) If given a chance, most people will try to take advantage of you. (IPTTA)*CODE IN REVERSE

\begin{tabular}{|l|l|}
\hline Strongly Agree (5) & \\
\hline Agree (4) & \\
\hline Neither Agree nor disagree (3) & \\
\hline Disagree (2) & \\
\hline Strongly Disagree (1) & \\
\hline DK (99) & \\
\hline NA (88) & \\
\hline
\end{tabular}

11E.) Generally, people do not try to take advantage of you. (IPTNA)

\begin{tabular}{|l|l|}
\hline Strongly Agree (5) & \\
\hline Agree (4) & \\
\hline Neither Agree nor disagree (3) & \\
\hline Disagree (2) & \\
\hline Strongly Disagree (1) & \\
\hline DK (99) & \\
\hline NA (88) & \\
\hline
\end{tabular}

Political Efficacy (PE---) 


\section{Show Card E}

I am going to read a series of statements, for each statement pleas indicate whether you: Strongly Agree; Agree; Neither agree nor disagree; Disagree; Strongly Disagree ; Do not know

12A.) If I have a problem, I feel I can ask for the help and cooperation of a member of the National Assembly. (PEHNC)

\begin{tabular}{|l|l|}
\hline Strongly Agree (5) & \\
\hline Agree (4) & \\
\hline Neither Agree nor disagree (3) & \\
\hline Disagree (2) & \\
\hline Strongly Disagree (1) & \\
\hline DK (99) & \\
\hline NA (88) & \\
\hline
\end{tabular}

12B.) If I have a problem, I feel I can ask for the help and cooperation of the mayor or his/her representative. (PEMMO)

\begin{tabular}{|l|l|}
\hline Strongly Agree (5) & \\
\hline Agree (4) & \\
\hline Neither Agree nor disagree (3) & \\
\hline Disagree (2) & \\
\hline Strongly Disagree (1) & \\
\hline DK (99) & \\
\hline NA (88) & \\
\hline
\end{tabular}

12C.) The government is responsive to the needs of society. (PERNS)

\begin{tabular}{|l|l|}
\hline Strongly Agree (5) & \\
\hline Agree (4) & \\
\hline Neither Agree nor disagree (3) & \\
\hline Disagree (2) & \\
\hline Strongly Disagree (1) & \\
\hline DK (99) & \\
\hline NA (88) & \\
\hline
\end{tabular}

12D.) My vote and participation in the electoral system is important. (PEVPI)

\begin{tabular}{|l|l|}
\hline Strongly Agree (5) & \\
\hline Agree (4) & \\
\hline Neither Agree nor disagree (3) & \\
\hline Disagree (2) & \\
\hline Strongly Disagree (1) & \\
\hline DK (99) & \\
\hline NA (88) & \\
\hline
\end{tabular}

12E.) Generally speaking, would you say that the government is run for the benefit of a few people, or for the benefit of the population as a whole? (PEGFP)

\begin{tabular}{|l|l|}
\hline For the benefit of population (2) & \\
\hline For the benefit of a few (1) & \\
\hline DK (99) & \\
\hline NA (88) & \\
\hline
\end{tabular}

\section{Show Card F}

12F.) In general, the actions of the Nicaraguan government are correct. (PETNG)

\begin{tabular}{|l|l|}
\hline Almost Always (5) & \\
\hline The majority of the time (4) & \\
\hline Some of the time (3) & \\
\hline Almost Never (2) & \\
\hline
\end{tabular}




\begin{tabular}{|l|l|}
\hline Never (1) & \\
\hline DK (99) & \\
\hline NA (88) & \\
\hline
\end{tabular}

12F1.) In general, the actions of the President of Nicaragua (Bolanos) are correct. (PETFG)

\begin{tabular}{|l|l|}
\hline Almost Always (5) & \\
\hline The majority of the time (4) & \\
\hline Some of the time (3) & \\
\hline Almost Never (2) & \\
\hline Never (1) & \\
\hline DK (99) & \\
\hline NA (88) & \\
\hline
\end{tabular}

12F2.) In general, the actions of the National Assembly are correct. ( PETRG)

\begin{tabular}{|l|l|}
\hline Almost Always (5) & \\
\hline The majority of the time (4) & \\
\hline Some of the time (3) & \\
\hline Almost Never (2) & \\
\hline Never (1) & \\
\hline DK (99) & \\
\hline NA (88) & \\
\hline
\end{tabular}

12F3.) In general, the actions of the municipal government in your community are correct? (PETLG)

\begin{tabular}{|l|l|}
\hline Almost Always (5) & \\
\hline The majority of the time (4) & \\
\hline Some of the time (3) & \\
\hline Almost Never (2) & \\
\hline Never (1) & \\
\hline DK (99) & \\
\hline NA (88) & \\
\hline
\end{tabular}

\section{Show Card G}

12G.) How much confidence do you have in the following organizations? (PEINC)

12G1.) The Catholic Church (PEINC1)

\begin{tabular}{|l|l|}
\hline Total confidence (5) & \\
\hline Quite a lot (4) & \\
\hline Some confidence (3) & \\
\hline Not very much (2) & \\
\hline None at all (1) & \\
\hline DK(99) & \\
\hline NA (88) & \\
\hline
\end{tabular}

12G2.) The church or denomination you attend if any. (PEINC2)

\begin{tabular}{|l|l|}
\hline Total confidence (5) & \\
\hline Quite a lot (4) & \\
\hline Some confidence (3) & \\
\hline Not very much (2) & \\
\hline None at all (1) & \\
\hline DK(99) & \\
\hline NA (88) & \\
\hline
\end{tabular}

12G3.) The public education system (PEINC3)

\begin{tabular}{|l|l|}
\hline Total confidence (5) & \\
\hline Quite a lot (4) & \\
\hline Some confidence (3) & \\
\hline Not very much (2) & \\
\hline None at all (1) & \\
\hline DK(99) & \\
\hline
\end{tabular}




\begin{tabular}{|l|l|}
\hline NA (88) & \\
\hline
\end{tabular}

12G4.) The judicial or legal system (PEINC4)

\begin{tabular}{|l|l|}
\hline Total confidence (5) & \\
\hline Quite a lot (4) & \\
\hline Some confidence (3) & \\
\hline Not very much (2) & \\
\hline None at all (1) & \\
\hline DK(99) & \\
\hline NA (88) & \\
\hline
\end{tabular}

12G5.) The Press (PEINC5)

\begin{tabular}{|l|l|}
\hline Total confidence (5) & \\
\hline Quite a lot (4) & \\
\hline Some confidence (3) & \\
\hline Not very much (2) & \\
\hline None at all (1) & \\
\hline DK(99) & \\
\hline NA (88) & \\
\hline
\end{tabular}

12G6.) Trade Unions (Organizaciones representantes de los comerciantes locales) (PEINC6)

\begin{tabular}{|l|l|}
\hline Total confidence (5) & \\
\hline Quite a lot (4) & \\
\hline Some confidence (3) & \\
\hline Not very much (2) & \\
\hline None at all (1) & \\
\hline DK(99) & \\
\hline NA (88) & \\
\hline
\end{tabular}

12G7.) Community Organizations (PIENC7)

\begin{tabular}{|l|l|}
\hline Total confidence (5) & \\
\hline Quite a lot (4) & \\
\hline Some confidence (3) & \\
\hline Not very much (2) & \\
\hline None at all (1) & \\
\hline DK(99) & \\
\hline NA (88) & \\
\hline
\end{tabular}

12G8.) The National Police (PEINC8)

\begin{tabular}{|l|l|}
\hline Total confidence (5) & \\
\hline Quite a lot (4) & \\
\hline Some confidence (3) & \\
\hline Not very much (2) & \\
\hline None at all (1) & \\
\hline DK(99) & \\
\hline NA (88) & \\
\hline
\end{tabular}

12G9.) The National Assembly (PEINC9)

\begin{tabular}{|l|l|}
\hline Total confidence (5) & \\
\hline Quite a lot (4) & \\
\hline Some confidence (3) & \\
\hline Not very much (2) & \\
\hline None at all (1) & \\
\hline DK(99) & \\
\hline NA (88) & \\
\hline
\end{tabular}

12G10.) Major Companies (Las Grand Empresas y companies) (PEINC10)

\begin{tabular}{|l|l|}
\hline Total confidence (5) & \\
\hline Quite a lot (4) & \\
\hline Some confidence (3) & \\
\hline
\end{tabular}




\begin{tabular}{|l|l|}
\hline Not very much (2) & \\
\hline None at all (1) & \\
\hline DK(99) & \\
\hline NA (88) & \\
\hline
\end{tabular}

12G11.) The Political System of Nicaragua (PEINC11)

\begin{tabular}{|l|l|}
\hline Total confidence (5) & \\
\hline Quite a lot (4) & \\
\hline Some confidence (3) & \\
\hline Not very much (2) & \\
\hline None at all (1) & \\
\hline DK(99) & \\
\hline NA (88) & \\
\hline
\end{tabular}

12G12.) The President of Nicaragua (PEINC12)

\begin{tabular}{|l|l|}
\hline Total confidence (5) & \\
\hline Quite a lot (4) & \\
\hline Some confidence (3) & \\
\hline Not very much (2) & \\
\hline None at all (1) & \\
\hline DK(99) & \\
\hline NA (88) & \\
\hline
\end{tabular}

\section{Support for Gradual Change (GC---)}

\section{Show Card E}

I am going to read a series of statements, for each statement pleas indicate whether you: Strongly Agree; Agree; Neither agree nor disagree; Disagree; Strongly Disagree ; Do not know

13A.) A priority of the government (central) is to maintain stability and order in the nation (GCSSO)

\begin{tabular}{|l|l|}
\hline Strongly Agree (5) & \\
\hline Agree (4) & \\
\hline Neither Agree nor disagree (3) & \\
\hline Disagree (2) & \\
\hline Strongly Disagree (1) & \\
\hline DK (99) & \\
\hline NA (88) & \\
\hline
\end{tabular}

13B.) I feel the government should move more rapidly in solving social problems (GCGTS)* CODE IN REVERSE

\begin{tabular}{|l|l|}
\hline Strongly Agree (5) & \\
\hline Agree (4) & \\
\hline Neither Agree nor disagree (3) & \\
\hline Disagree (2) & \\
\hline Strongly Disagree (1) & \\
\hline DK (99) & \\
\hline NA (88) & \\
\hline
\end{tabular}

13C.) The structure and organization of Nicaraguan society needs to be changed through the actions of revolutionaries. (GCSRC)*CODE IN REVERSE

\begin{tabular}{|l|l|}
\hline Strongly Agree (1) & \\
\hline Agree (2) & \\
\hline Neither Agree nor disagree (3) & \\
\hline Disagree (4) & \\
\hline Strongly Disagree (5) & \\
\hline DK (99) & \\
\hline NA(88) & \\
\hline
\end{tabular}


13D.) Our society must be gradually improved through reforms. (GCGIR)

\begin{tabular}{|l|l|}
\hline Strongly Agree (5) & \\
\hline Agree (4) & \\
\hline Neither Agree nor disagree (3) & \\
\hline Disagree (2) & \\
\hline Strongly Disagree (1) & \\
\hline DK (99) & \\
\hline NA (88) & \\
\hline
\end{tabular}

13E.) Nicaraguan society must be defended against all subversive forces (GCDAS)

\begin{tabular}{|l|l|}
\hline Strongly Agree (5) & \\
\hline Agree (4) & \\
\hline Neither Agree nor disagree (3) & \\
\hline Disagree (2) & \\
\hline Strongly Disagree (1) & \\
\hline DK (99) & \\
\hline NA (88) & \\
\hline
\end{tabular}

13F.) Signing a petition is an acceptable form of political expression (GCPPA)

\begin{tabular}{|l|l|}
\hline Strongly Agree (5) & \\
\hline Agree (4) & \\
\hline Neither Agree nor disagree (3) & \\
\hline Disagree (2) & \\
\hline Strongly Disagree (1) & \\
\hline DK (99) & \\
\hline NA (88) & \\
\hline
\end{tabular}

13G.) Joining a boycott is an acceptable form of political expression (GCBPA)

\begin{tabular}{|l|l|}
\hline Strongly Agree (5) & \\
\hline Agree (4) & \\
\hline Neither Agree nor disagree (3) & \\
\hline Disagree (2) & \\
\hline Strongly Disagree (1) & \\
\hline DK (99) & \\
\hline NA (88) & \\
\hline
\end{tabular}

13H.) Attending lawful demonstrations is an acceptable form of political expression (GCLDA)

\begin{tabular}{|l|l|}
\hline Strongly Agree (5) & \\
\hline Agree (4) & \\
\hline Neither Agree nor disagree (3) & \\
\hline Disagree (2) & \\
\hline Strongly Disagree (1) & \\
\hline DK (99) & \\
\hline NA (88) & \\
\hline
\end{tabular}

13I.) Occupying buildings or factories are acceptable forms of political expression (GCOBA)

\begin{tabular}{|l|l|}
\hline Strongly Agree (5) & \\
\hline Agree (4) & \\
\hline Neither Agree nor disagree (3) & \\
\hline Disagree (2) & \\
\hline Strongly Disagree (1) & \\
\hline DK (99) & \\
\hline NA (88) & \\
\hline
\end{tabular}

\section{Show Card H}


13J.) There are people who have only negative things to say about the government. To what extent do you agree with the right of these people to vote. (GCSVV)

\begin{tabular}{|l|l|}
\hline Strongly Agree (5) & \\
\hline Agree (4) & \\
\hline Neither Agree nor disagree (3) & \\
\hline Disagree (2) & \\
\hline Strongly Disagree (1) & \\
\hline DK (99) & \\
\hline NA (88) & \\
\hline
\end{tabular}

13K.) There are people who have only negative things to say about the government. To what extent do you agree with the right of these people to hold peaceful public demonstrations for the purpose of expressing their views. (GCSSD)

\begin{tabular}{|l|l|}
\hline Strongly Agree (5) & \\
\hline Agree (4) & \\
\hline Neither Agree nor disagree (3) & \\
\hline Disagree (2) & \\
\hline Strongly Disagree (1) & \\
\hline DK (99) & \\
\hline NA (88) & \\
\hline
\end{tabular}

13L.) There are people who have only negative things to say about the government. To what extent do you agree with the right of these people to run for political office? (GCSPO)

\begin{tabular}{|l|l|}
\hline Strongly Agree (5) & \\
\hline Agree (4) & \\
\hline Neither Agree nor disagree (3) & \\
\hline Disagree (2) & \\
\hline Strongly Disagree (1) & \\
\hline DK (99) & \\
\hline NA (88) & \\
\hline
\end{tabular}

13M.) There are people who have only negative things to say about the government. To what extent to you agree with the right of these people to appear on radio or television or make public speeches? (GCSRS)

\begin{tabular}{|l|l|}
\hline Strongly Agree (5) & \\
\hline Agree (4) & \\
\hline Neither Agree nor disagree (3) & \\
\hline Disagree (2) & \\
\hline Strongly Disagree (1) & \\
\hline DK (99) & \\
\hline NA (88) & \\
\hline
\end{tabular}

\section{Show Card I}

13N.) What is your attitude toward the economic progress of Nicaragua today? (GCAEP)

\begin{tabular}{|l|l|}
\hline Muy bien progresso (5) & \\
\hline Bien progresso(4) & \\
\hline Mas o menos progresso (3) & \\
\hline Mal progresso (2) & \\
\hline Muy mal progresso (1) & \\
\hline DK (99) & \\
\hline NA (88) & \\
\hline
\end{tabular}

13O.) On this page there is a scale that goes from left to right. Today when people discuss political tendencies, they talk about "rightists" and "leftists", that is, people sympathesize more with the left (FSLN) or the right (PLC). According with what the terms left or right mean to you when you think of your own point of view, where would you place yourself? (GCLRC) 


\begin{tabular}{|l|l|l|l|l|l|l|l|l|l|l|l|}
\hline Left & 1 & 2 & 3 & 4 & 5 & 6 & 7 & 8 & 9 & 10 & Right \\
\hline
\end{tabular}

Religious Background (RB---)

14A.) Which religious denomination do you consider to be you primary provider? (RBPRP)

\begin{tabular}{|l|l|}
\hline Catholic (1) & \\
\hline Protestant (2) & \\
\hline Evangelico (3) & \\
\hline Baptist (4) & \\
\hline Methodist (5) & \\
\hline Pentecostal (6) & \\
\hline Mormon (7) & \\
\hline Seventh Day Adventist (8) & \\
\hline Jehovah's Witness (9) & \\
\hline Jewish (10) & \\
\hline Muslim (11) & \\
\hline Other: (12) & \\
\hline None (13) & \\
\hline DK (14) & \\
\hline
\end{tabular}

14A1.) Catholic or not Catholic - NOT ASKED _ TAKEN FROM ABOVE (RBCON)

\begin{tabular}{|l|l|}
\hline Catholic (1) & \\
\hline Not Catholic (0) & \\
\hline NA (88) & \\
\hline DK (99) & \\
\hline
\end{tabular}

14B.) Do you consider yourself to be a member of more than one denomination? (RBMOD)

\begin{tabular}{|l|l|}
\hline Yes (2) & \\
\hline No (1) & \\
\hline DK (99) & \\
\hline NA (88) & \\
\hline
\end{tabular}

14B1.) If yes (14B), what other religions do you practice? (RBORP)

14B2.) If yes (14B), which religion do practice most often? (RBNOC)

14B3.) If yes (14B), how long have you been attending this other religion? (RBYOA)

14B4.) When did you convert? (RBNYA)

14B5.) Why did you convert? (RBRFC)

\section{Show Card E}

14C.) I am going to read you a list of religious denominations, using this card indicate which statement best describes your attitude toward that denomination. (RBAOD)

14C1.) The Catholic Church (RBAOD1)

\begin{tabular}{|l|l|}
\hline Strongly Agree (5) & \\
\hline Agree (4) & \\
\hline Neither Agree nor disagree (3) & \\
\hline Disagree (2) & \\
\hline Strongly Disagree (1) & \\
\hline DK (99) & \\
\hline NA (88) & \\
\hline
\end{tabular}

14C2.) Christian Base Communities (RBAOD2)

\begin{tabular}{|l|l|}
\hline Strongly Agree (5) & \\
\hline Agree (4) & \\
\hline Neither Agree nor disagree (3) & \\
\hline Disagree (2) & \\
\hline Strongly Disagree (1) & \\
\hline DK (99) & \\
\hline
\end{tabular}




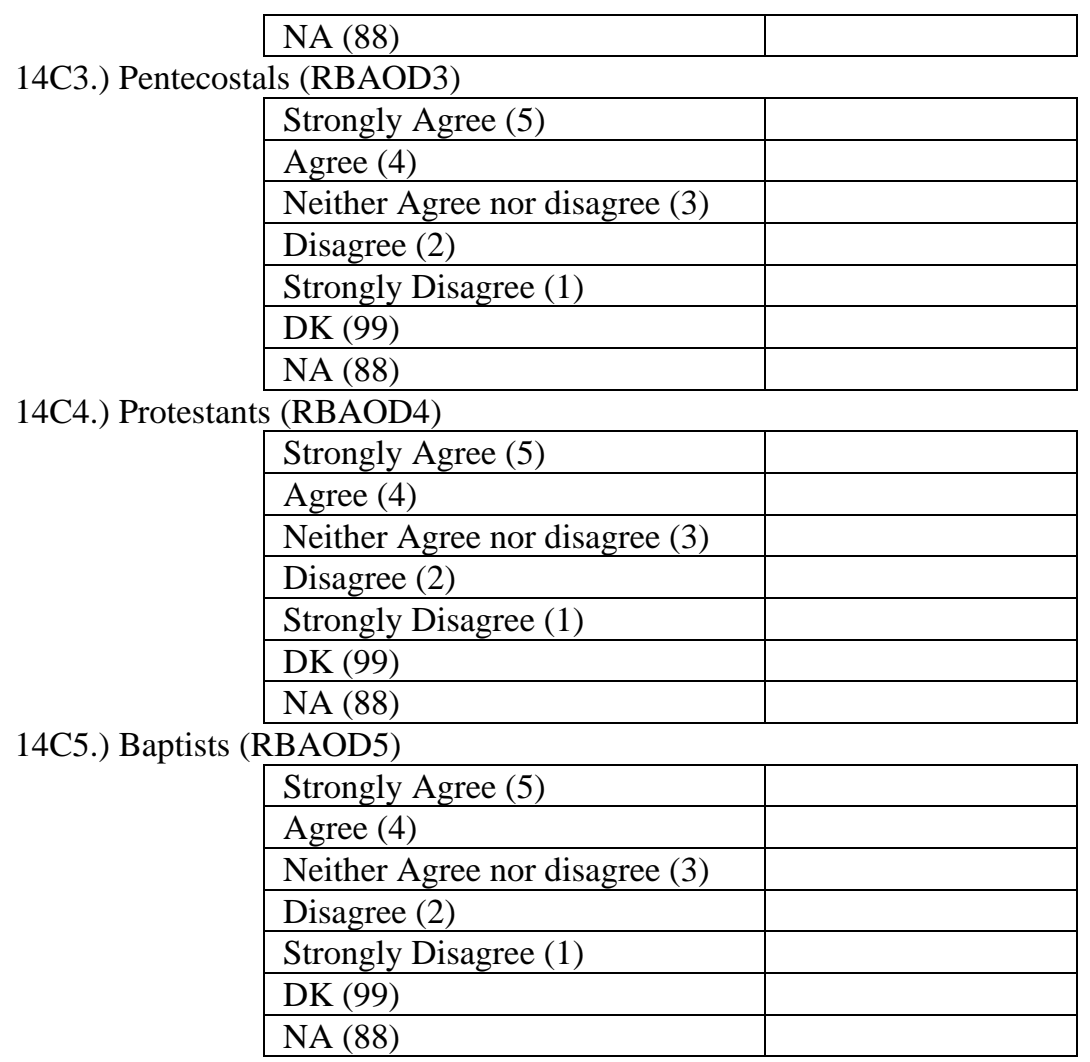

14C6.) Evangelicals (RBAOD6)

\begin{tabular}{|l|l|}
\hline Strongly Agree (5) & \\
\hline Agree (4) & \\
\hline Neither Agree nor disagree (3) & \\
\hline Disagree (2) & \\
\hline Strongly Disagree (1) & \\
\hline DK (99) & \\
\hline NA (88) & \\
\hline
\end{tabular}

14C7.) Seventh Day Adventists (RBAOD7)

\begin{tabular}{|l|l|}
\hline Strongly Agree (5) & \\
\hline Agree (4) & \\
\hline Neither Agree nor disagree (3) & \\
\hline Disagree (2) & \\
\hline Strongly Disagree (1) & \\
\hline DK (99) & \\
\hline NA (88) & \\
\hline
\end{tabular}

14C8.) Jehovah’s Witnesses (RBAOD8)

\begin{tabular}{|c|c|}
\hline & Strongly Agree (5) \\
\hline & Agree (4) \\
\hline & Neither Agree nor disagree (3) \\
\hline & Disagree (2) \\
\hline & Strongly Disagree (1) \\
\hline & DK (99) \\
\hline & NA (88) \\
\hline 14C9.) Mormon & (RBAOD9) \\
\hline & Strongly Agree (5) \\
\hline & Agree (4) \\
\hline & Neither Agree nor disagree (3) \\
\hline
\end{tabular}




\begin{tabular}{|l|l|}
\hline Disagree (2) & \\
\hline Strongly Disagree (1) & \\
\hline DK (99) & \\
\hline NA (88) & \\
\hline
\end{tabular}

14C10.) Muslim (RBAOD10)

\begin{tabular}{|l|l|}
\hline Strongly Agree (5) & \\
\hline Agree (4) & \\
\hline Neither Agree nor disagree (3) & \\
\hline Disagree (2) & \\
\hline Strongly Disagree (1) & \\
\hline DK (99) & \\
\hline NA (88) & \\
\hline
\end{tabular}

14C11.) Hindu (RBAOD11)

\begin{tabular}{|l|l|}
\hline Strongly Agree (5) & \\
\hline Agree (4) & \\
\hline Neither Agree nor disagree (3) & \\
\hline Disagree (2) & \\
\hline Strongly Disagree (1) & \\
\hline DK (99) & \\
\hline NA (88) & \\
\hline
\end{tabular}

\section{Show Card E}

I am going to read a series of statements, for each statement pleas indicate whether you: Strongly Agree; Agree; Neither agree nor disagree; Disagree; Strongly Disagree ; Do not know

14D.) The Bible contains the word of God and everything this says is literally true. (RBBLT)

\begin{tabular}{|l|l|}
\hline Strongly Agree (5) & \\
\hline Agree (4) & \\
\hline Neither Agree nor disagree (3) & \\
\hline Disagree (2) & \\
\hline Strongly Disagree (1) & \\
\hline DK (99) & \\
\hline NA (88) & \\
\hline
\end{tabular}

14E.) Eternal life is only possible for those who believe in Jesus Christ as God and Savior (RBHBG)

\begin{tabular}{|l|l|}
\hline Strongly Agree (5) & \\
\hline Agree (4) & \\
\hline Neither Agree nor disagree (3) & \\
\hline Disagree (2) & \\
\hline Strongly Disagree (1) & \\
\hline DK (99) & \\
\hline NA (88) & \\
\hline
\end{tabular}

14F.) Religion does not provide me with a guide for my daily life (RBRGL)* CODE IN REVERSE

\begin{tabular}{|l|l|}
\hline Strongly Agree (1) & \\
\hline Agree (2) & \\
\hline Neither Agree nor disagree (3) & \\
\hline Disagree (4) & \\
\hline Strongly Disagree (5) & \\
\hline DK (99) & \\
\hline NA (88) & \\
\hline
\end{tabular}

14G.) Religious organizations can be effective in addressing problems of the community (RBRAP) Strongly Agree (5) 


\begin{tabular}{|l|l|}
\hline Agree (4) & \\
\hline Neither Agree nor disagree (3) & \\
\hline Disagree (2) & \\
\hline Strongly Disagree (1) & \\
\hline DK (99) & \\
\hline NA (88) & \\
\hline
\end{tabular}

14H.) The religious organizations and church to which I belong should work to solve social problems (RBSSP)

\begin{tabular}{|l|l|}
\hline Strongly Agree (5) & \\
\hline Agree (4) & \\
\hline Neither Agree nor disagree (3) & \\
\hline Disagree (2) & \\
\hline Strongly Disagree (1) & \\
\hline DK (99) & \\
\hline NA (88) & \\
\hline
\end{tabular}

14I) Please indicate whether you believe in any of the following (RBWTB)

14I1.) God (RBWTB1)

\begin{tabular}{|l|l|}
\hline Yes (2) & \\
\hline No (1) & \\
\hline DK (99) & \\
\hline NA (88) & \\
\hline
\end{tabular}

14I2.) Life after death (RBWTB2)

\begin{tabular}{|l|l|}
\hline Yes (2) & \\
\hline No (1) & \\
\hline DK (99) & \\
\hline NA (88) & \\
\hline
\end{tabular}

14I3.) A Soul (RBWTB3)

\begin{tabular}{|l|l|}
\hline Yes (2) & \\
\hline No (1) & \\
\hline DK (99) & \\
\hline NA (88) & \\
\hline
\end{tabular}

14I4.) The Devil (RBWTB4)

\begin{tabular}{|l|l|}
\hline Yes (2) & \\
\hline No (1) & \\
\hline DK (99) & \\
\hline NA (88) & \\
\hline
\end{tabular}

14I5.) Hell (RBWTB5)

\begin{tabular}{|l|l|}
\hline Yes (2) & \\
\hline No (1) & \\
\hline DK (99) & \\
\hline NA (88) & \\
\hline
\end{tabular}

14I6.) Heaven (RBWTB6)

\begin{tabular}{|l|l|}
\hline Yes (2) & \\
\hline No (1) & \\
\hline DK (99) & \\
\hline NA (88) & \\
\hline
\end{tabular}

14I7.) Sin (RBWTB7)

\begin{tabular}{|l|l|}
\hline Yes (2) & \\
\hline No (1) & \\
\hline DK (99) & \\
\hline
\end{tabular}




\begin{tabular}{|l|l|}
\hline NA (88) & \\
\hline
\end{tabular}

14I8.) Resurrection of the Dead (RBWTB8)

\begin{tabular}{|l|l|}
\hline Yes (2) & \\
\hline No (1) & \\
\hline DK (99) & \\
\hline NA (88) & \\
\hline
\end{tabular}

14I9.) Reincarnation (RBWTB9)

\begin{tabular}{|l|l|}
\hline Yes (2) & \\
\hline No (1) & \\
\hline DK (99) & \\
\hline NA (88) & \\
\hline
\end{tabular}

14J.) On a scale from $1 \mathrm{t}$ o10, with 10 being very important and 1 being not important at all: How important is God in your life? (RBIGL)

\begin{tabular}{|l|l|}
\hline 1 & \\
\hline 2 & \\
\hline 3 & \\
\hline 4 & \\
\hline 5 & \\
\hline 6 & \\
\hline 7 & \\
\hline 8 & \\
\hline 9 & \\
\hline 10 & \\
\hline DK (99) & \\
\hline NA (88) & \\
\hline
\end{tabular}

14K.) Do you find strength and comfort from religious? (RBRSC)

\begin{tabular}{|l|l|}
\hline Yes (2) & \\
\hline No (1) & \\
\hline DK (99) & \\
\hline NA (88) & \\
\hline
\end{tabular}

14L.) How often do you pray outside of religious services? Would you say ... (RBPOR)

\begin{tabular}{|l|l|}
\hline Always (5) & \\
\hline Sometimes (4) & \\
\hline Almost Never (3) & \\
\hline Only in times of crisis (2) & \\
\hline Never (1) & \\
\hline DK (99) & \\
\hline NA (88) & \\
\hline
\end{tabular}

14M.) Independently of whether or not you go to church, would you say you are a .... (RBTRP)

\begin{tabular}{|l|l|}
\hline A religious person (3) & \\
\hline Not a religious person (2) & \\
\hline Atheist (1) & \\
\hline DK (99) & \\
\hline NA (88) & \\
\hline
\end{tabular}

\section{Show Card B}


14N.) Do you believe it is appropriate for your church to speak out on...(RBCRS)

14N1.) Disarmament (RBCRS1)

\begin{tabular}{|l|l|}
\hline Yes (2) & \\
\hline No (1) & \\
\hline DK (99) & \\
\hline NA (88) & \\
\hline
\end{tabular}

14N2.) Abortion (RBCRS2) **** DID NOT WORK: MISINTERPRETED

\begin{tabular}{|l|l|}
\hline Yes (2) & \\
\hline No (1) & \\
\hline DK (99) & \\
\hline NA (88) & \\
\hline
\end{tabular}

14N3.) Problems of the Third World (RBCRS3)

\begin{tabular}{|l|l|}
\hline Yes (2) & \\
\hline No (1) & \\
\hline DK (99) & \\
\hline NA (88) & \\
\hline
\end{tabular}

14N4.) Extramarital Affairs (RBCRS4)

\begin{tabular}{|l|l|}
\hline Yes (2) & \\
\hline No (1) & \\
\hline DK (99) & \\
\hline NA (88) & \\
\hline
\end{tabular}

14N5.) Drug Addiction (RBCRS5)

\begin{tabular}{|l|l|}
\hline Yes (2) & \\
\hline No (1) & \\
\hline DK (99) & \\
\hline NA (88) & \\
\hline
\end{tabular}

14N6.) Alcoholism (RBCRS6)

\begin{tabular}{|l|l|}
\hline Yes (2) & \\
\hline No (1) & \\
\hline DK (99) & \\
\hline NA (88) & \\
\hline
\end{tabular}

14N7.) Unemployment (RBCRS7)

\begin{tabular}{|l|l|}
\hline Yes (2) & \\
\hline No (1) & \\
\hline DK (99) & \\
\hline NA (88) & \\
\hline
\end{tabular}

14N8.) Racial Discrimination (RBCRS8)

\begin{tabular}{|l|l|}
\hline Yes (2) & \\
\hline No (1) & \\
\hline DK (99) & \\
\hline NA (88) & \\
\hline
\end{tabular}

14N9.) Euthanasia (RBCRS9) $* * * * *$

\begin{tabular}{|l|l|}
\hline Yes (2) & \\
\hline No (1) & \\
\hline DK (99) & \\
\hline NA (88) & \\
\hline
\end{tabular}

14N10.) Homosexuality (RBCRS10)

\begin{tabular}{|l|l|}
\hline Yes (2) & \\
\hline No (1) & \\
\hline DK (99) & \\
\hline NA (88) & \\
\hline
\end{tabular}

14N11.) Ecology and the Environment (RBCRS11)

Yes (2) 


\begin{tabular}{|l|l|}
\hline No (1) & \\
\hline DK (99) & \\
\hline NA (88) & \\
\hline
\end{tabular}

14N12.) Politics and Government (RBCRS12)

\begin{tabular}{|l|l|}
\hline Yes (2) & \\
\hline No (1) & \\
\hline DK (99) & \\
\hline NA (88) & \\
\hline
\end{tabular}

14N13.) Human Rights (RBCRS13)

\begin{tabular}{|l|l|}
\hline Yes (2) & \\
\hline No (1) & \\
\hline DK (99) & \\
\hline NA (88) & \\
\hline
\end{tabular}

14O.) Generally speaking, do you think that your church is giving, in your country, adequate answers to the following: (RBCPA)

14O1.) The moral needs and problems of the individual? (RBCPA1)

\begin{tabular}{|l|l|}
\hline Yes (2) & \\
\hline No (1) & \\
\hline DK (99) & \\
\hline NA (88) & \\
\hline
\end{tabular}

14O2.) The problems of family life (RBCPA2)

\begin{tabular}{|l|l|}
\hline Yes (2) & \\
\hline No (1) & \\
\hline DK (99) & \\
\hline NA (88) & \\
\hline
\end{tabular}

14O3.) The spiritual needs of the population (RBCPA3)

\begin{tabular}{|l|l|}
\hline Yes (2) & \\
\hline No (1) & \\
\hline DK (99) & \\
\hline NA (88) & \\
\hline
\end{tabular}

14O4.) The social problems facing the country (RBCPA4)

\begin{tabular}{|l|l|}
\hline Yes (2) & \\
\hline No (1) & \\
\hline DK (99) & \\
\hline NA (88) & \\
\hline
\end{tabular}

14O5.) The financial problems facing individuals (RBCPA5)

\begin{tabular}{|l|l|}
\hline Yes (2) & \\
\hline No (1) & \\
\hline DK (99) & \\
\hline NA (88) & \\
\hline
\end{tabular}

14O6.) A sense or source of community (RBCPA6)

\begin{tabular}{|l|l|}
\hline Yes (2) & \\
\hline No (1) & \\
\hline DK (99) & \\
\hline NA (88) & \\
\hline
\end{tabular}

Demographic Information (DI---)

15A.) Male or Female 1 Male 0 Female (DIGEN)

15B.) What year were you born? (DIAGE)

15C.) What was the last year of school you completed? (DIEDU)

\begin{tabular}{|l|l|}
\hline College $+(5)$ & \\
\hline College (4) & \\
\hline Secondary (3) & \\
\hline
\end{tabular}




\begin{tabular}{|l|l|}
\hline Elementary (2) & \\
\hline None (1) & \\
\hline DK (99) & \\
\hline
\end{tabular}

15D.) In your best estimate, what is your minimum income per month (DIINC) -- CORDOBAS

15E.) In your best estimate, what is you family's minimum income per month (DIINCF) -- CORDOBAS

15F.) Do you live in a house or apartment? (2) House (1) Apartment (DILAH)

15G.) How many people live in your house or apartment? (DINOP)

15H.) How many people over the age of 18 live in your house or apartment (DIOLD)?

15I.) How many people under the age of 18 live in your house or apartment (DIYTH)?

15J.) Do you own your house or apartment or do you rent? (DIOWN)

\begin{tabular}{|l|l|}
\hline Own (2) & \\
\hline Rent (1) & \\
\hline DK (99) & \\
\hline NA (88) & \\
\hline
\end{tabular}

15K.) Do you have a telephone? (DITEL)

\begin{tabular}{|l|l|}
\hline Yes (2) & \\
\hline No (1) & \\
\hline DK (99) & \\
\hline NA (88) & \\
\hline
\end{tabular}

15L.) Do you have a refrigerator? (DIREF)

\begin{tabular}{|l|l|}
\hline Yes (2) & \\
\hline No (1) & \\
\hline DK (99) & \\
\hline NA (88) & \\
\hline
\end{tabular}

15M.) What material is the floor of you house made of (observe do not ask)? (DIFLR)

\begin{tabular}{|l|l|}
\hline Tile (4) & \\
\hline Concrete (3) & \\
\hline Dirt (2) & \\
\hline Other (1) & \\
\hline DK (99) & \\
\hline NA (88) & \\
\hline
\end{tabular}

$15 \mathrm{~N}$.$) How is your residence roofed (observe do not ask)? (DIROF)$

\begin{tabular}{|l|l|}
\hline Terracotta (4) & \\
\hline Shingle (3) & \\
\hline Zinc (2) & \\
\hline Thatch (1) & \\
\hline DK (99) & \\
\hline NA (88) & \\
\hline
\end{tabular}

15O.) What is you occupation (DIJOB)

15P.) How many years have you done this kind of work (DIYRJ)

15Q.) Do you listen to news on the radio daily? (DINOR)

\begin{tabular}{|l|l|}
\hline Yes (2) & \\
\hline No (1) & \\
\hline DK (99) & \\
\hline NA (88) & \\
\hline
\end{tabular}

15R.) If no on $15 \mathrm{Q}$ how often do you listen to the news on the radio per week? (DINRW) 15S.) Do you have a television? (DIHTV)

\begin{tabular}{|l|l|}
\hline Yes (2) & \\
\hline No (1) & \\
\hline DK (99) & \\
\hline NA (88) & \\
\hline
\end{tabular}

15T.) How often do you watch the news on television? (DINTV) 


\begin{tabular}{|l|l|}
\hline Daily (5) & \\
\hline 2 or 3 times a week (4) & \\
\hline Once a week (3) & \\
\hline Monthly (2) & \\
\hline Never (1) & \\
\hline DK (99) & \\
\hline NA (88) & \\
\hline
\end{tabular}

15U.) Do you usually read the news paper? (DIRNP)

\begin{tabular}{|l|l|}
\hline Yes (2) & \\
\hline No (1) & \\
\hline DK (99) & \\
\hline NA (88) & \\
\hline
\end{tabular}

15V.) How often do you read the news paper (DIFNP)

\begin{tabular}{|l|l|}
\hline Daily (5) & \\
\hline 2 or 3 times a week (4) & \\
\hline Once a week (3) & \\
\hline Monthly (2) & \\
\hline Never (1) & \\
\hline DK (99) & \\
\hline NA (88) & \\
\hline
\end{tabular}


Appendix 2: Index Variable Definitions 


\section{DEPENDENT VARIABLES}

CIVIL SOCIETY VARIABLES

Formal Civil Society Index (FOCIND)

Informal Civil Society Participation Index (ICSPIN)

Informal Civil Society Support Index (ICSSIN)

Informal Civil Society Total Index (ICSTIN)

EFFECTS OF CIVIL SOCIETY

Political Efficacy Index (POLEF)

Political Knowledge Index (PKIND)

Interpersonal Trust Index (IPTRUST)

OPINIONS ABOUT GOVERNMENT

Belief Actions of Government are Correct Index (BGAIND)

Confidence in Government Index (CIGIND)

POLITICAL TOLERANCE

Alternative Political Expression Acceptance Index (APEIND)

Openness of Participation (OPINDX2)

\section{INDEPENDENT VARIABLES}

\section{RELIGIOSITY}

Level of Religious Participation (RBLRP)

Level of Religious Value (RBLRV)

Level of Religious Belief (RBLRB)

Levels of Role of Religions in Society (RBRRCS), (RBCRRS 1), (RBCRRS 2)

Level of Religious Success in Society (RBCPAI)

RELIGIOUS DENOMINATION

Primary Religious Provider (RBPRP)

Catholics, CEB, Other Christians (Evangelical), Non-Christian (RBPRP)

AGE

2003 - year of birth (DIAGE1)

INCOME

Based on estimated family income (DIINFC)

GENDER

Gender (DIGEN)

EDUCATIONAL ATTAINMENT

What was the last grade or year of school you attended (DIEDU) 


\section{Civil Society Indices}

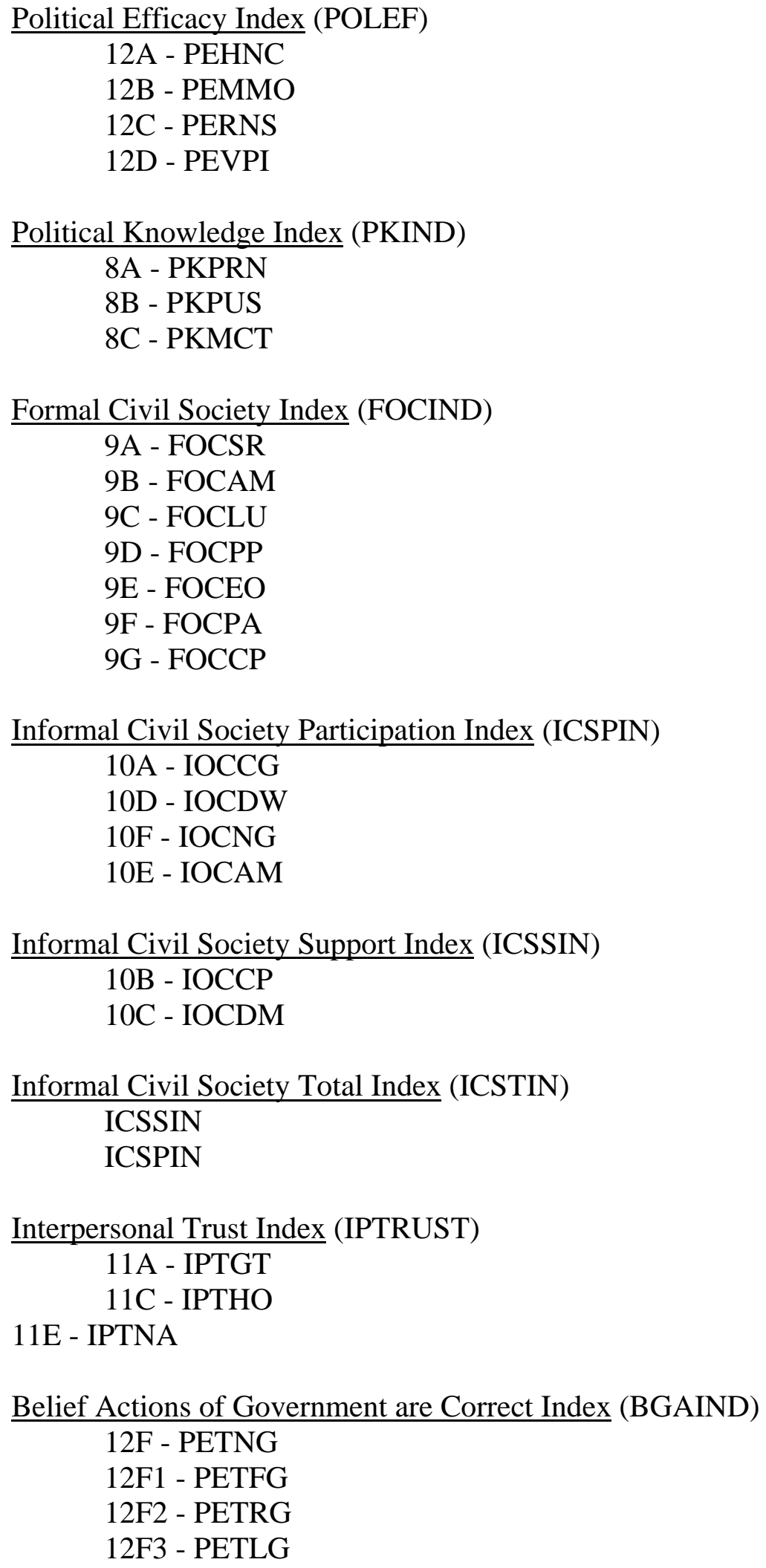

Formal Civil Society Index (FOCIND)

$$
\begin{aligned}
& \text { 9A - FOCSR } \\
& \text { 9B - FOCAM } \\
& \text { 9C - FOCLU } \\
& \text { 9D - FOCPP } \\
& \text { 9E - FOCEO } \\
& \text { 9F - FOCPA } \\
& \text { 9G - FOCCP }
\end{aligned}
$$

Informal Civil Society Participation Index (ICSPIN)

$$
\begin{aligned}
& \text { 10A - IOCCG } \\
& \text { 10D - IOCDW } \\
& \text { 10F - IOCNG } \\
& \text { 10E - IOCAM }
\end{aligned}
$$

Informal Civil Society Support Index (ICSSIN)

$$
\begin{aligned}
& \text { 10B - IOCCP } \\
& \text { 10C - IOCDM }
\end{aligned}
$$

Informal Civil Society Total Index (ICSTIN)

ICSSIN

ICSPIN

Interpersonal Trust Index (IPTRUST)

11A - IPTGT

11C - IPTHO

11E - IPTNA

Belief Actions of Government are Correct Index (BGAIND)

$12 \mathrm{~F}$ - PETNG

12F1 - PETFG

12F2 - PETRG

12F3 - PETLG 
Confidence in Government Index (CIGIND)

12G3 - PEINC3 (Public Education System)

12G4 - PEINC4 (Legal/Judicial System)

12G8 - PEINC7 (Police)

12G9 - PEINC8 (The National Assembly)

12G11 - PEINC10 (Political System)

12G12 - PEINC11 (President of Nicaragua)

Alternative Political Expression Acceptance Index (APEIND)

13I - GCOBA

$13 \mathrm{H}$ - GCLDA

13G - GCPBA

13F - GCPPA

Openness of Participation (OPINDX2)

13J - GCSSV

13K - GCSSD

13L - GCSPO

$13 \mathrm{M}$ - GCSRS

\section{Religiosity Indices}

Level of Religious Participation (RBLRP)

14L - RBPOR

14M - RBTRP

Level of Religious Value (RBLRV)

14D - RBBLT

14E - RBHGB

$14 \mathrm{~K}$ - RBRSC

Level of Religious Belief (RBLRB)

$14 \mathrm{I} 1$ - RBWTB1

14I2 - RBWTB2

14I3 - RBWTB3

14I4 - RBWTB4

$14 \mathrm{I} 5$ - RBWTB5

$14 \mathrm{I} 6$ - RBWTB6

$14 \mathrm{I} 7$ - RBWTB7

$14 \mathrm{I} 8$ - RBWTB8 
Levels of Role of Religions in Society (RBRRCS)

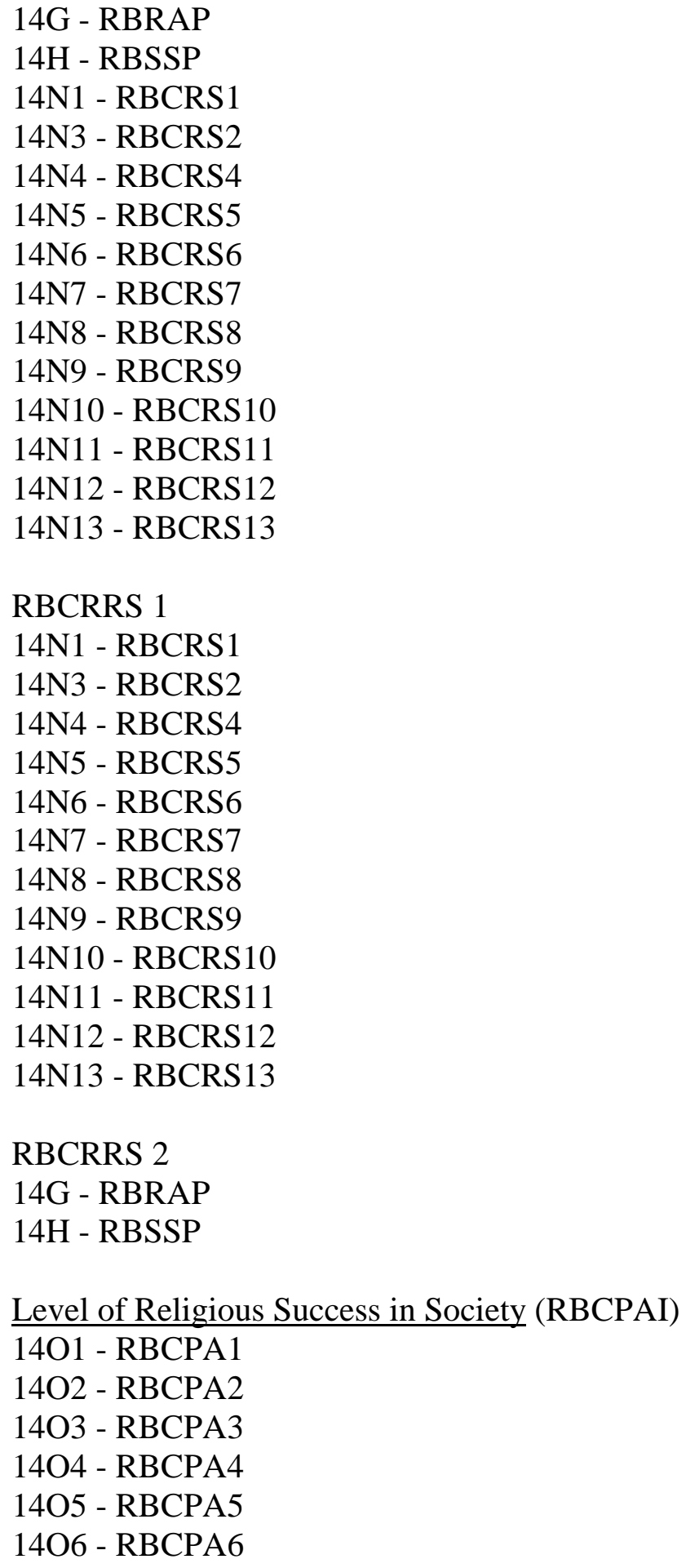

